\title{
Urban Waste Grease Resource Assessment
}

\author{
G. Wiltsee
}

Appel Consultants, Inc. Valencia, California

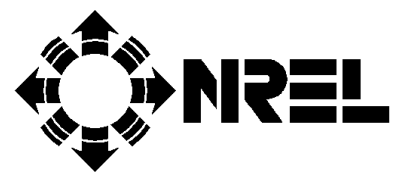

National Renewable Energy Laboratory 1617 Cole Boulevard Golden, Colorado 80401-3393

A national laboratory of the U.S. Department of Energy Managed by Midwest Research Institute for the U.S. Department of Energy under contract No. DE-AC36-83CH10093 


\section{Urban Waste Grease Resource Assessment}

\section{G. Wiltsee}

Appel Consultants, Inc.

Valencia, California

NREL technical monitor: K.S. Tyson

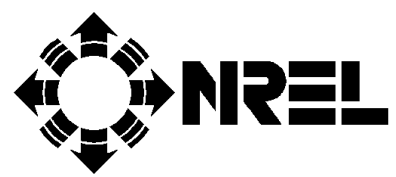

National Renewable Energy Laboratory 1617 Cole Boulevard

Golden, Colorado 80401-3393

A national laboratory of the U.S. Department of Energy Managed by Midwest Research Institute for the U.S. Department of Energy under contract No. DE-AC36-83CH10093

Prepared under Subcontract No. ACG-7-17090-01

November 1998 
This publication was reproduced from the best available copy Submitted by the subcontractor and received no editorial review at NREL

\section{NOTICE}

This report was prepared as an account of work sponsored by an agency of the United States government. Neither the United States government nor any agency thereof, nor any of their employees, makes any warranty, express or implied, or assumes any legal liability or responsibility for the accuracy, completeness, or usefulness of any information, apparatus, product, or process disclosed, or represents that its use would not infringe privately owned rights. Reference herein to any specific commercial product, process, or service by trade name, trademark, manufacturer, or otherwise does not necessarily constitute or imply its endorsement, recommendation, or favoring by the United States government or any agency thereof. The views and opinions of authors expressed herein do not necessarily state or reflect those of the United States government or any agency thereof.

Available to DOE and DOE contractors from:

Office of Scientific and Technical Information (OSTI)

P.O. Box 62

Oak Ridge, TN 37831

Prices available by calling (423) 576-8401

Available to the public from:

National Technical Information Service (NTIS)

U.S. Department of Commerce

5285 Port Royal Road

Springfield, VA 22161

(703) $605-6000$ or (800) 553-6847

or

DOE Information Bridge

http://www.doe.gov/bridge/home.html 


\section{CONTENTS}

\section{Section}

Page

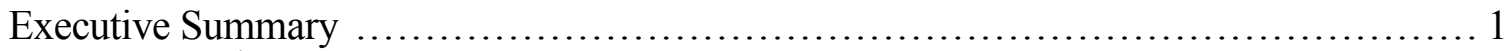

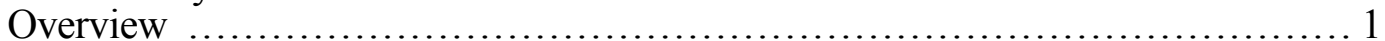

Yellow Grease ......................................................... 3

Trap Grease Collected by Tank Trucks ........................................ 4

Restaurant Grease Flowing Directly to Wastewater Treatment Plants .............. 6

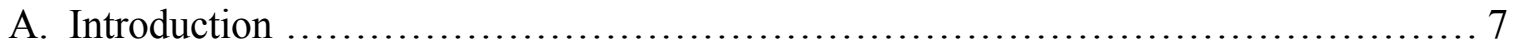

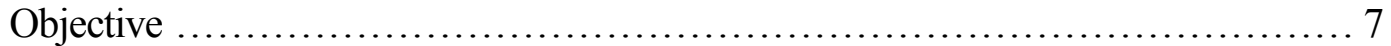

Review of Existing Urban Waste Grease Resource Assessments .................. 7

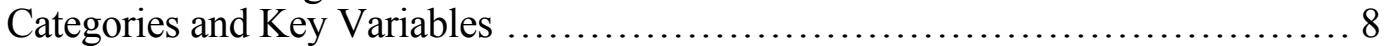

Sample of US Metropolitan Areas .......................................... 9

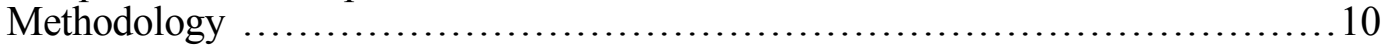

B. Overview of Urban Waste Grease Resource Data .................................... 12

Urban Waste Grease Resources ................................................. 12

Statistical Analysis of the Data ............................................ 12

C. Metropolitan Area Reports .................................................... 15

1. Sacramento, California ….......................................... 15

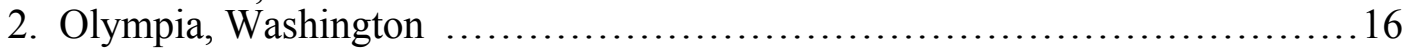

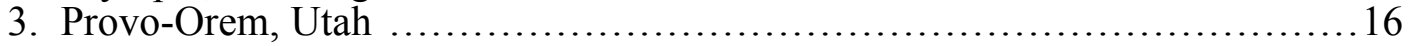

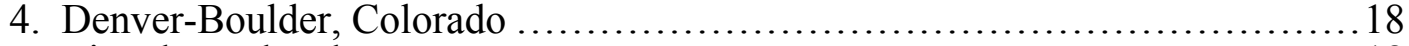

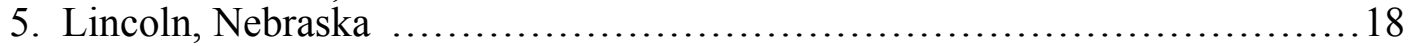

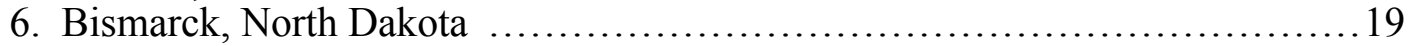

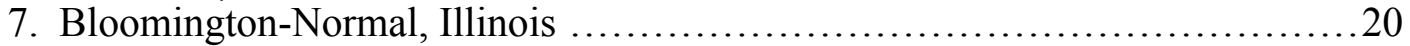

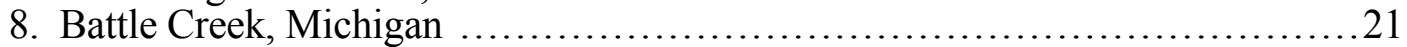

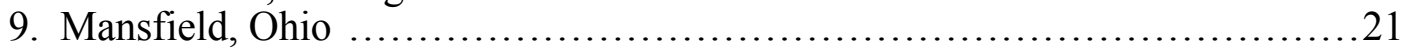

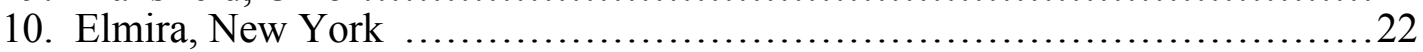

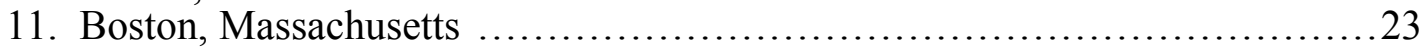

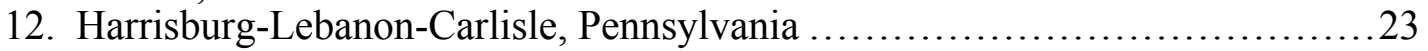

13. Altoona, Pennsylvania ......................................................... 24

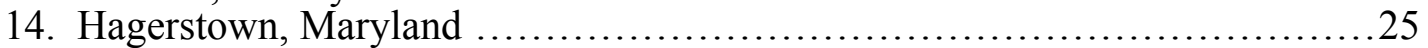

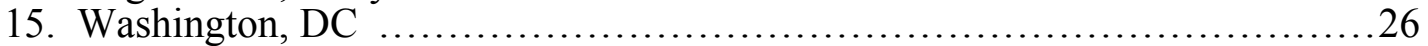

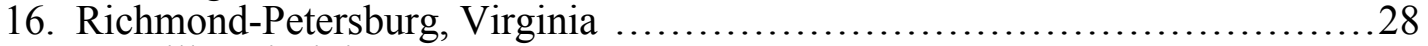

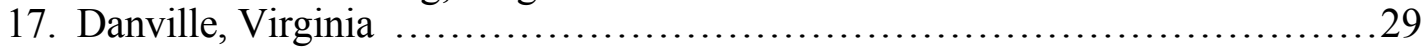

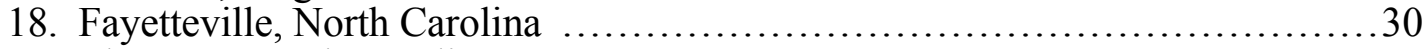

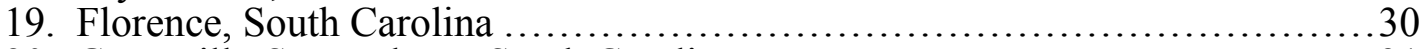

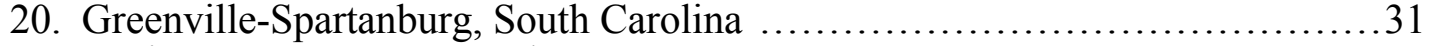

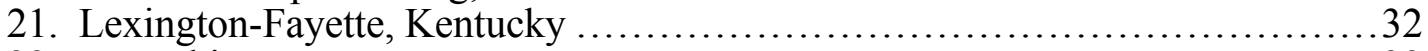

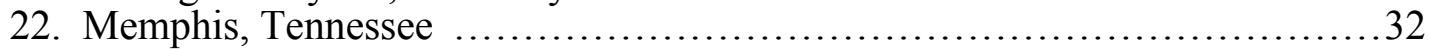

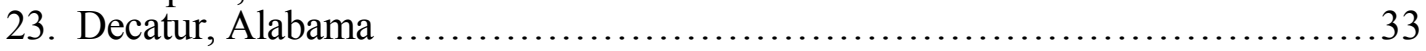

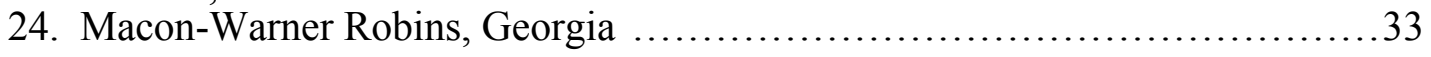


C. Metropolitan Area Reports (continued)

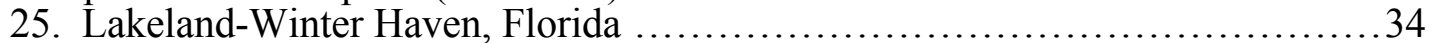

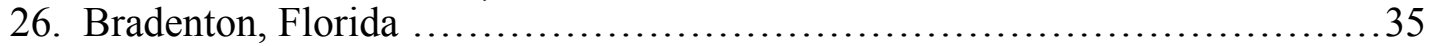

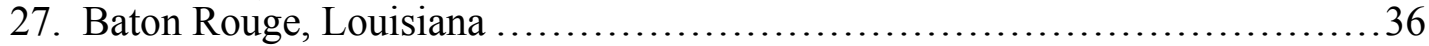

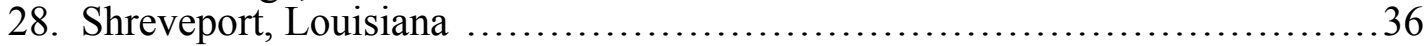

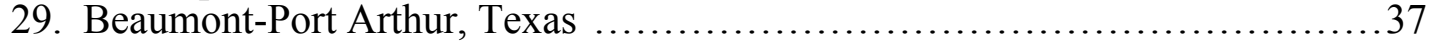

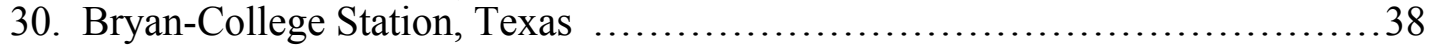

Appendices

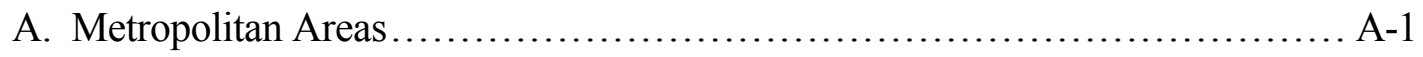

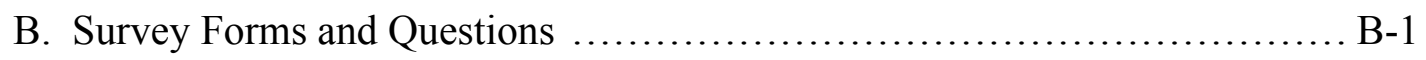

C. Regression Plots ....................... 


\section{TABLES}

Table

Page

1. Urban Waste Grease Resources in 30 Metropolitan Areas, Pounds/Year/Person ...... 2

2. US Production, Consumption, and Potential Biodiesel Supply from Tallow

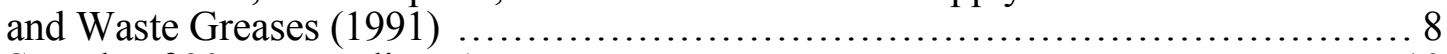

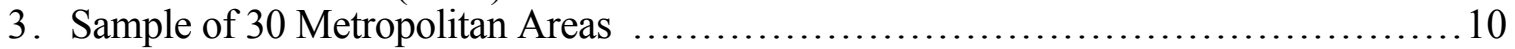

4. Size Distributions: Sample of 30 and 281 US Metropolitan Areas ..................11

5. Urban Waste Grease Resources in 30 Metropolitan Areas, Pounds/Year ..............13

6. Urban Waste Grease Resources in 30 Metropolitan Areas, Pounds/Year/Person ......14 


\section{EXECUTIVE SUMMARY}

\section{Overview}

This study, which was funded by the US Department of Energy's National Renewable Energy Laboratory (NREL), collected and analyzed data on urban waste grease resources in 30 randomly selected metropolitan areas in the United States. The metropolitan areas ranged in size from Bismarck, North Dakota $(83,831)$ to Washington, DC $(3,923,574)$. Two major categories of urban waste grease were considered in this study:

1) yellow grease feedstock collected from restaurants by rendering companies; and

2) grease trap wastes from restaurants, which can either:

a. be pumped into tank trucks for disposal (often at wastewater treatment plants) or processing (at rendering plants or other facilities); or

b. flow through municipal sewage systems into wastewater treatment plants.

Yellow grease feedstock is a valuable commodity, used to manufacture tallow, animal feed supplements, and other products. Grease trap waste and grease entering sewage treatment plants are zero or negative cost feedstocks at their sources, but are contaminated with sewage components. Other than collecting information on tipping fees, this study did not address feedstock preparation and cost issues.

The number of restaurants in most of the 30 metropolitan areas studied is quite consistent, at about 1.4 restaurants per 1,000 people. Cultural and dietary preferences greatly affect the amount of grease used in cooking. The amount of grease discarded from certain fast food restaurants is especially high. Despite significant local variations among neighborhoods' grease outputs, when entire metropolitan areas are considered the quantities of grease are reasonably consistent on a per capita (and a per restaurant) basis.

The amount of yellow grease feedstock collected from restaurants ranged from about 3 to $21 \mathrm{pounds} /$ year/person, or about 2,000 to 13,000 pounds/year/restaurant for the metropolitan areas sampled in this study. Many rendering companies refused to provide data, so factored estimates were used in many of the cities. The combined resource of collected grease trap waste and uncollected grease entering sewage treatment plants ranged from about 2 to 27 pounds/year/person, or about 800 to 17,000 pounds/year/restaurant. Thus, a metropolitan area the size of Washington, DC (which includes suburban Maryland and Northern Virginia) generates about 39,000,000 pounds/year of yellow grease feedstock and about 50,000,000 pounds/year of grease trap waste.

Table 1 summarizes the data collected in this study on a per capita basis, in pounds of grease per year, per person. The table also shows the metropolitan area populations and the number of restaurants per 1,000 people in each area. The numbers in front of the metropolitan areas represent the order in which the areas were visited. City names 
followed by dashes indicate that additional cities are included in the official name of the metropolitan area (e.g., Provo-Orem).

Table 1

Urban Waste Grease Resources in 30 Metropolitan Areas Pounds/Year/Person

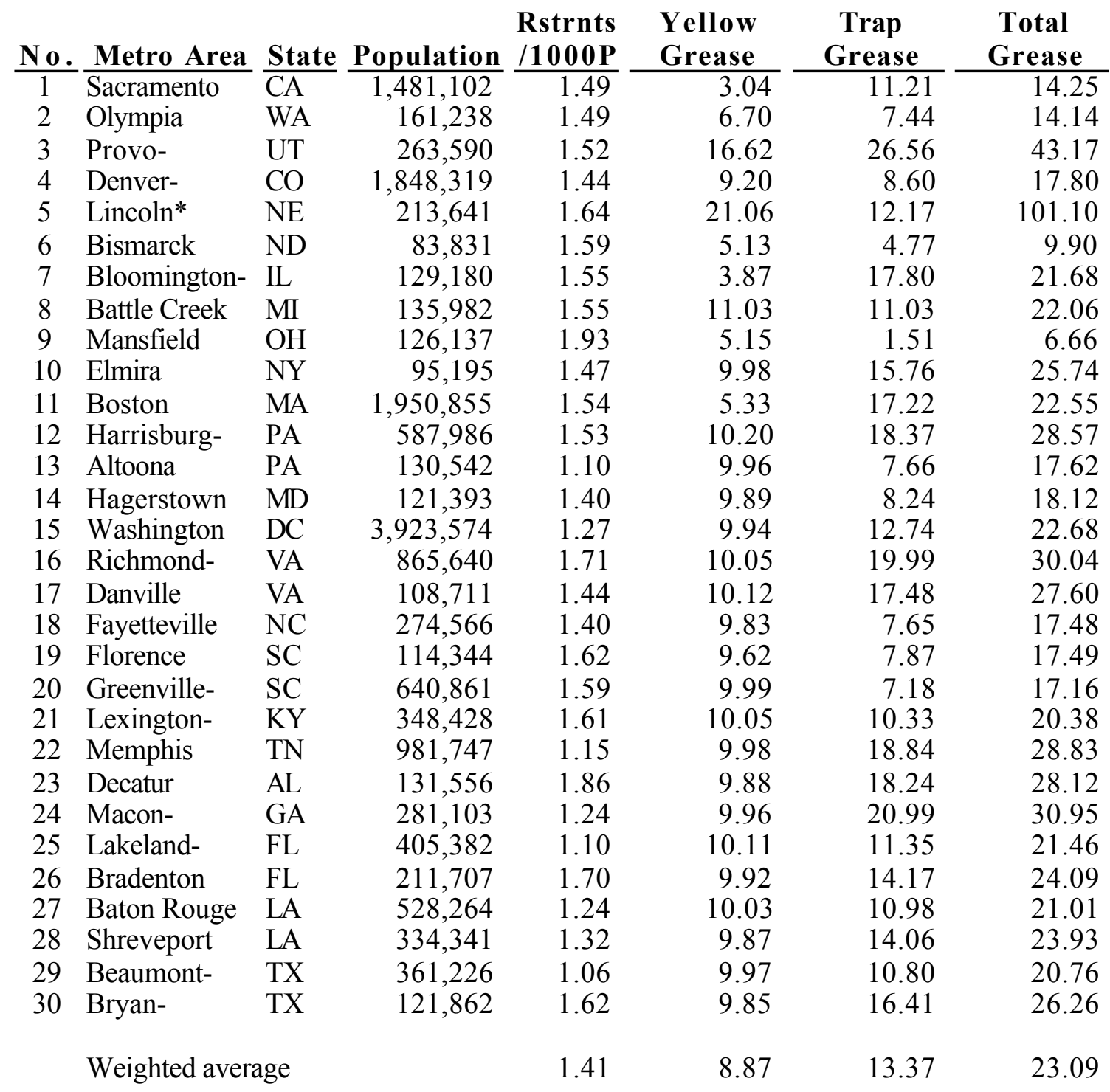

*Lincoln total includes 67.87 pounds/year/person of food plant waste grease.

There is not much variability from one urban area to another in the number of restaurants per 1,000 people. The number is between 1 and 2 for all 30 cities, and usually in the middle of this range, with a weighted average of 1.41 restaurants/1,000 people. Regression analysis shows that the best fit line has a coefficient (slope) of 1.36 restaurants/1,000 people, with an r-squared value of 0.985. Based on this finding, we would expect that the number of restaurants and the number of people in a metropolitan 
area give about the same ability to predict the quantities of waste grease resources in that area. Regression analysis showed that this is indeed the case, as summarized below:

\section{vs. Population}

Weighted average, pounds/year/person

Regression coefficient, $1 \mathrm{~b} / \mathrm{y} / \mathrm{p}$

R squared

vs. Number of Restaurants

Weighted average, pounds/year/restaurant

Regression coefficient, $\mathrm{lb} / \mathrm{y} / \mathrm{r}$

R squared

\begin{tabular}{|c|c|c|}
\hline Yellow & Trap & Total \\
\hline Grease & Grease & Grease \\
\hline 8.87 & 13.37 & 23.09 \\
\hline 8.74 & 13.11 & 21.96 \\
\hline 0.901 & 0.924 & 0.930 \\
\hline
\end{tabular}

$\begin{array}{llc}6,268 & 9,453 & 16,325 \\ 6,256 & 9,553 & 15,903 \\ 0.849 & 0.921 & 0.908\end{array}$

The population of a metropolitan area, state, or other geographic area is generally easier to obtain than the number of restaurants in that area. Rounding off to reflect a reasonable number of significant digits, the urban waste grease resources of a metropolitan area, region, state, or the US as a whole can be predicted from the following simple equations:

- Yellow grease, pounds/year/person $=9$

- $\quad$ Trap grease, pounds/year/person $=13$

- $\quad$ Total waste grease, pounds/year/person $=22$

\section{Yellow Grease}

Rendering companies process grease and fat from restaurant kitchens, and produce tallow (most of which is exported to the Orient) and feed fat for use in animal feed. Prices for yellow grease fluctuate as with all commodities; during the past year they have been in the $10-20 \notin /$ pound range. Waste grease from restaurants appears to be growing in economic value and is the focus of intense competition in some cities. Some of the rendering companies are major companies with nationwide or large regional operations. The companies I encountered most often in the 30 metropolitan areas studied were:

- Valley Proteins, Inc. -- in nine metropolitan areas in the eastern US (Harrisburg, Altoona, Hagerstown, Washington, DC, Richmond, Danville, Florence, Greenville, and Lexington);

- Darling International, Inc. -- in eight metropolitan areas throughout the US (Olympia, Lincoln, Battle Creek, Lakeland, Baton Rouge, Shreveport, Beaumont, and Bryan);

- Griffin Industries, Inc. -- in seven metropolitan areas in the south (Memphis, Decatur, Macon, Lakeland, Bradenton, Baton Rouge, and Shreveport);

- Baker Commodities, Inc. -- in three metropolitan areas in the north (Olympia, Bismarck, and Boston);

- National Byproducts Company -- in Denver and Lincoln; and

- CBP Resources Inc. -- in Richmond and Fayetteville.

In addition, I encountered at least 23 other rendering companies in one metropolitan area each. The grease collection business in Provo-Orem, Utah is typical of those in many of 
the other metropolitan areas studied. Bonneville Livestock Inc. collects and processes about $55-60 \%$ of the restaurant grease in Utah, and also operates in four or five nearby states. Its manager described a competitive business, with John Kuhni \& Sons, American Commodities Co., and Renegade Oil Co. all vying for restaurant accounts in the ProvoOrem area. The manager at John Kuhni \& Sons stated that Renegade Oil Co. in Salt Lake City is his biggest competitor. In the Provo-Orem area, John Kuhni \& Sons picks up, on average, about two barrels every three weeks from about 70-75 restaurants. Assuming an average of 300 pounds of grease per barrel, this is equivalent to about 10,000 pounds/year/restaurant.

National Byproducts, Inc., which recently acquired Colorado Grease Company, appears to have the largest market share of the rendering companies serving the Denver-Boulder area. They pay some restaurants for grease, and do not pay some others (depending on volume and location). National has eight rendering plants in the mid-continent area, and provides bulk containers to its large customers (approximately $5 \times 3 \times 3$ feet) which get emptied into the collection trucks, instead of exchanging 55-gallon drums as most of the rendering companies do.

Valley Proteins Inc. was typical of many rendering companies in that my calls were answered by secretaries who took messages, but the managers did not return the calls, even after several call-backs. Some rendering company managers said if I sent them a letter with my questions they would take a look at it, but that chances were good they would not respond with any quantitative information. I did not bother. Others were friendly and gave me qualitative information such as the names of the companies serving the metropolitan area and their approximate market shares, but stayed away from giving out data on quantities of grease collected. A few rendering company managers gave me their "estimates" of quantities of grease collected from restaurants in certain metropolitan areas. It was impossible to verify these estimates.

The amount of yellow grease feedstock recovered per restaurant varies greatly for different types of restaurants. Jack-in-the-Box restaurants generate two or three times as much grease as McDonald's, whereas Denny's restaurants produce about $2 / 3$ as much as McDonald's. A typical small family restaurant generates about $1 / 3$ as much grease per day as a McDonald's.

\section{Trap Grease Collected by Tank Trucks}

Most of the cities in the survey have a "grease traps" section in the yellow pages, which typically lists a small number of companies. Usually these companies are septic tank service companies that also provide grease trap service, usually with different trucks (depending on local regulations). If the yellow pages had no listings for grease traps, I was usually able to find several companies listed under septic tank service that also provided grease trap service. In some areas I found that rendering companies also pump out grease traps.

In general, attempts to develop estimates of the total amounts of grease trap wastes collected by tank trucks by asking the service companies themselves for the data were not successful. There were too many non-respondents or respondents who did not keep good records. After the first few metropolitan areas, my interview technique for these companies had evolved to a very short set of questions designed to find out where the grease trap pump trucks discharged the material and what the local regulations concerning such discharges were. If the answer was the local wastewater treatment plant, I would try to get information on quantities from the wastewater treatment plant, and usually met with 
success. If the answer was evasive, or honestly indicated that the material was being dumped somewhere, it was necessary to use a factored estimate.

Some cities and counties are grappling with the political issue of how best to handle grease trap wastes. Most wastewater treatment plant managers feel that from a technical point of view it is best to have strong regulations requiring restaurants to have grease traps pumped regularly, and to have the waste discharged at wastewater treatment plants where it can be properly treated and disposed of. However, local politics and lobbying by business owners often create much less effective approaches to the problem. In some areas, there are no legal or permitted approaches to disposing of grease trap wastes, forcing it to be done illegally. Data collection in such areas is essentially impossible.

Regulations in some areas (e.g., California) are moving towards collection and processing of grease trap wastes by rendering companies instead of disposal in wastewater treatment plants. Newer restaurants in some areas of California are required to install interceptors instead of traditional grease traps. An interceptor is a larger device that can be visualized as a wide spot in the line that allows cleaner grease to be recovered.

In some cities, pump trucks drive to designated sites and discharge grease trap wastes to manholes that provide a "straight shot" to the wastewater treatment plant. In effect, restaurant grease is prevented from flowing through the narrow drains and piping at the beginning of the collection system, but is reinjected into the main sewage stream near the treatment plant where the lines are wide and plugging is not a concern. More commonly, trucks are required to discharge grease trap wastes at the wastewater treatment plant, where accurate records can be kept and sources can be monitored. Some plants have pretreatment systems designed specifically for grease trap wastes. One pretreatment manager (in Altoona, Pennsylvania) places bacteria in several manholes to allow the pretreatment process to start before the sewage arrives at the plant.

Some wastewater treatment plants not only accept material pumped from restaurant grease traps; they accept food processing grease wastes as well. In Lincoln, Nebraska, one wastewater treatment plant receives not only all of the grease trap wastes collected in the metropolitan area, but also waste grease from an ADM soybean processing plant and a Cook Foods ham and bacon plant. In Memphis, one wastewater treatment plant receives effluent from a Protein Tech soybean processing plant and a Cargill corn processing plant.

Grease trap wastes in the Provo-Orem area are delivered to a soils regeneration operation in Salt Lake City, where oily wastes and greases are bioremediated using microbes and nutrients. Materials are blended and composted; the product is used as topsoil for the final cover on closed landfill sites. In the Boston area, grease trap pumping companies discharge pump trucks at processing facilities that charge tipping fees such as $11 \% /$ gallon for grease trap waste and $6 \notin /$ gallon for septage. One major septic service company treats its own grease trap material, recovering the grease and landfilling the rest. In the LakelandWinter Haven and Bradenton, Florida metropolitan areas, several companies recover and process grease trap wastes. Nopec Corporation converts grease into biodiesel fuel, and septic tank service companies separate the waste grease from water, adjust the $\mathrm{pH}$ of the grease with lime, and land spread the material in accordance with permits from county and state environmental agencies. The Natural Solution Inc. in Shreveport uses a patented bioremediation process (bacteria) to convert grease to inert solids. Grease trap pump trucks in Bryan-College Station discharge at a wastewater treatment plant, where a private company processes the material with bacteria. The gray water enters the treatment plant and the solids go to a landfill. 
In Harrisburg, Pennsylvania, a grease trap pumping company dewaters the material in a plate and frame filter press and hauls the grease cake to the Harrisburg Refuse Incinerator. Grease trap pumping companies in the Port Arthur, Texas area discharge their wastes at the Chemical Waste Management incinerator nearby, which receives hundreds of different types of wastes and chemicals, including PCBs and other hazardous wastes. The Beaumont, Texas wastewater treatment plant currently accepts grease trap discharges, but a plant is under construction by a private company that will convert the grease trap wastes to products. When this plant is operating, the Beaumont wastewater treatment plant will stop accepting grease trap discharges.

Data collected on grease trap wastes are subject to inherent inaccuracies because this material can include a significant amount of water and other materials mixed with the grease. In fact, the usable grease content may be as low as $5-10 \%$. In all cases, the estimates in this report were adjusted to provide a best estimate of the amount of grease contained in the grease trap waste.

\section{Restaurant Grease Flowing Directly to Wastewater Treatment Plants}

Grease traps are not $100 \%$ effective in capturing grease that goes down restaurant drains, and restaurant owners are not uniformly diligent (depending on local regulations and enforcement) in having grease traps serviced at regular intervals. In addition, households and other establishments discharge food wastes and grease to the sewer system. Motor oils and industrial oils are also included in the "oil and grease" component that makes its way into wastewater treatment plants. Some wastewater treatment plant laboratories report the oil and grease content of their influent wastewater in the units milligrams $(\mathrm{mg}) /$ liter; others report in parts per million ( $\mathrm{ppm})$. It turns out that these two sets of units are the same, because water weighs 1,000 grams/liter.

Although there is considerable variation, the amount of raw sewage entering wastewater treatment plants in the 30 metropolitan areas averages about 110 gallons per day per person. The range was from 36 gallons/day/person in the Harrisburg-Lebanon-Carlisle, Pennsylvania metropolitan area to 247 gallons/day/person in the Provo-Orem, Utah area. These values are the average flow rates reported by the plant managers; flow rates during rainstorms are much higher.

The concentrations of oil and grease measured in the raw sewage to wastewater treatment plants in the 30 metropolitan areas generally fall in the range of 20 to $50 \mathrm{ppm}$. The most detailed information I received on this subject was for a group of five plants in the Maryland suburbs of Washington, DC. Although individual (daily) measurements ranged from 1.2 to $206 \mathrm{ppm}$, the annual average concentrations for all five plants fell in the range of 27 to $38 \mathrm{ppm}$. It appeared from these data that $35 \mathrm{ppm}$ was a good average value for the oil and grease concentration in the raw sewage in DC and its Maryland suburbs. 


\section{A. INTRODUCTION}

\section{Objective}

The National Renewable Energy Laboratory (NREL) stated the following objective in funding this work: "The objective of this work is to develop a cost effective methodology for estimating urban waste grease quantities and values on a state and regional scale for the United States; and implement it to produce state-level urban waste grease data. If successful, this research will provide a replicable methodology for others to use."

\section{Review of Existing Urban Waste Grease Resource Assessments}

There are relatively few published reports that provide data and analyses of urban waste grease resources in the US. In fact, only a small number of published articles provide any information on waste grease resources in the US; those that were found in this literature search are summarized below.

Richard G. Nelson et. al. (Kansas State University), "Potential Feedstock Supply and Costs for Biodiesel Production", in Proceedings of BIOENERGY '94, the Sixth National Bioenergy Conference, Reno/Sparks, Nevada, October 2-6, 1994. The majority of tallow (edible and inedible) in the US is generated by the meat packing, poultry, and edible/inedible rendering industries. Most edible tallow is used as baking and frying fats, margarine and other edible products. Inedible tallow is mainly used as an animal feed supplement (62.4\%), with minor uses as fatty acid feedstock (22.4\%), soaps and lubricants. Waste grease discarded by food service operations (the resource of interest here) can be processed to produce a mixture of waste oils and fats known as yellow grease. A majority of yellow grease is used as an added fat source for animal feeds (64\%), as a feedstock for industrial fatty acids $(4 \%)$, or as a diluent for higher grade inedible products $(7 \%)$, with the remainder being exported.

Researchers believe that biodiesel derived from inedible tallow and greases has significant potential in certain locations such as large cities (yellow grease) and possible rural locations that are in close proximity to large cattle slaughtering facilities (inedible tallow). Nelson presents data on national edible tallow production taken from the US Department of Agriculture - Economic Research Service (USDA-ERS) "Oil Crops, Situation and Outlook Report", and data on inedible tallow from the US Department of Commerce, Bureau of the Census M20K Reports. These data are summarized in Table 2.

Thomas B. Reed (Colorado School of Mines), "An Overview of the Current Status of Biodiesel", in Proceedings, First Biomass Conference of the Americas, Burlington, Vermont, August 30-September 2, 1993. Reed mentions that the US Department of Agriculture maintains the Northern Agriculture Energy Center in Peoria, IL to work primarily in the area of oils and fats. He states that waste fat (yellow grease) typically sells for $\$ 0.60-\$ 1.00 /$ gallon and estimates that it can be converted to biodiesel for $\$ 0.60 /$ gallon.

Frank Pudel and Peter Lengenfeld (OEHMI Forschung und Ingenieurtechnik GmbH, Magdeburg, Germany), "Processing Waste Fats into a Fuel Oil Substitute", in Proceedings, First Biomass Conference of the Americas, Burlington, Vermont, August 30September 2, 1993. In several branches of industry, especially in the food industry, fats of 
biological origin result as wastes that need to be disposed of. The primary sources are: fats that were used for deep-frying, cooking, or baking; fatty wastes such as tank slurries; returned fatty foods; fats from fat traps of sewage treatment plants; and technical oils of biological origin like lubricating, hydraulic, or drill oils.

\title{
Table 2 \\ US Production, Consumption, and Potential Biodiesel Supply from Tallow and Waste Greases (1991)
}

\author{
Edible Tallow \\ Total production, million pounds/year $\quad 1,515$ \\ Consumption 1,183 \\ Potential biodiesel from total production, \\ million gallons/year \\ Inedible Tallow and Waste Greases \\ Total production, million pounds/year \\ Inedible tallow \\ 196 \\ Greases \\ Consumption \\ Potential biodiesel from total production, \\ million gallons/year

1,515
1,183
196

3,603
2,167
2,993
747

Jesse Katz, Los Angeles Times, "The Rancid Riches of Texas' New Range War", August 22, 1997. Subheadlines: "Lucrative recycling industry fuels demand for restaurants' used cooking oil. Across this fry cook's nirvana, big entrepreneurs and rogue operators battle over who gets the goo." Waste grease from restaurants is a commodity that is growing in economic value and is the focus of intense competition in some cities.

The rendering industry lives off waste grease, recycling it as an additive in soap, cosmetics, lubricants and livestock feed, among other uses. The largest renderers sign contracts with restaurants, installing grease vats in kitchen alleys and paying a few cents per pound every time they come for a load. That arrangement, however, rarely goes unchallenged. Rogue haulers often snatch the grease before the big companies can get there -- a phenomenon that has led to criminal probes, civil lawsuits and other charges of slippery commerce. A poacher can earn 7 to 14 cents a pound, depending on the demand for rendered grease, which is bought and sold each day on the commodities market.

I interviewed a person from Darling International, a large rendering company based in Dallas, TX that has operations all over the US. They process grease and fat from restaurant kitchens, and produce tallow (95\% of which is exported to the Orient) and feed fat for use in animal feed. Prices fluctuate as with all commodities, but recently have been in the 15-20ф/pound range. It is possible that some of these markets and prices may be threatened by concerns over "mad cow disease." If so, it is possible that used cooking oil could become available as a tipping fee waste in some locations. At the present time in most locations, the only waste grease that fits that description is grease trap waste, which is contaminated with other sewage material. Most grease trap waste ends up being treated in municipal wastewater treatment systems.

\section{Categories and Key Variables}

The amount of yellow grease feedstock recovered per restaurant varies greatly for different types of restaurants. Jack-in-the-Box restaurants generate two or three times as much 
grease as McDonald's, whereas Denny's restaurants produce about $2 / 3$ as much as McDonald's. A typical small family restaurant generates about $1 / 3$ as much grease per day as a McDonald's. Thus, the demographics of the area and types of restaurants serviced by the rendering company reporting the data can greatly affect the estimated total quantities of grease recovered.

Data collected on grease trap wastes are subject to inherent inaccuracies because this material can include a significant amount of water and other materials mixed with the grease. In fact, the usable grease content may be as low as 5-10\%. In contrast, the grease/oil quantities reported by the laboratories at some wastewater treatment plants are based on gravimetric analyses of total raw sewage, thus eliminating water and other contaminants or diluents from the estimates. In all cases, a best effort has been made in this report to adjust grease trap resource data to include only the grease, and to exclude water and other materials that may be present. These adjustments necessarily involved assumptions and considerable uncertainty.

Some wastewater treatment plant laboratories report the oil and grease content of their influent wastewater in the units $\mathrm{mg} /$ liter; others report in parts per million ( $\mathrm{ppm})$. It turns out that these two sets of units are the same, because water weighs 1,000 grams/liter. Therefore, one $\mathrm{mg} /$ liter is the same as one gram per million grams, or one $\mathrm{ppm}$.

Some cities and counties are grappling with the political issue of how best to handle grease trap wastes. Most wastewater treatment plant managers feel that from a technical point of view it is best to have strong regulations requiring restaurants to have grease traps pumped regularly, and to have the waste discharged at the wastewater treatment plants where it can be properly treated and disposed of. However, local politics and lobbying by business owners often create much less effective approaches to the problem. In some areas, there are no legal or permitted approaches to disposing of grease trap wastes, forcing it to be done illegally. Data collection in such areas is essentially impossible.

\section{Sample of US Metropolitan Areas}

The United States Office of Management and Budget (OMB) defines metropolitan areas according to published standards that are applied to Census Bureau data. The general concept of a metropolitan area is that of a core area containing a large population nucleus, together with adjacent communities having a high degree of economic and social integration with that core. The current (1996) standards provide that each newly qualifying metropolitan area must include at least one city with 50,000 or more inhabitants, or a Census Bureau-defined urbanized area (of at least 50,000 inhabitants) and a total metropolitan population of at least 100,000 (75,000 in New England).

The Census Bureau report "State and Metropolitan Area Data Book 1991" (based on the 1990 census) lists 281 metropolitan areas in the United States (See Appendix A). The total 1990 population of the 281 metropolitan areas in the US was 193,007,670, which is $77.4 \%$ of the total July 1, 1990 US population of 249,397,990. A sample of 30 metropolitan areas was selected randomly for this study. The initial sample was reviewed to make sure it reflected a good cross-section of the nation geographically, and that it was representative of the total group of 281 metropolitan areas in terms of size distribution. Three substitutions were made for these reasons, resulting in the sample of 30 metropolitan areas shown in Table 3 . Table 4 shows how the sample of 30 compares to the total of 281 metropolitan areas in size distribution. 
Table 3

Sample of 30 Metropolitan Areas

\begin{tabular}{|c|c|c|c|}
\hline No. & Metropolitan Area & State & Population \\
\hline 1 & Sacramento & $\mathrm{CA}$ & $1,481,102$ \\
\hline 2 & Olympia & WA & 161,238 \\
\hline 3 & Provo-Orem & UT & 263,590 \\
\hline 4 & Denver-Boulder & $\mathrm{CO}$ & $1,848,319$ \\
\hline 5 & Lincoln & $\mathrm{NE}$ & 213,641 \\
\hline 6 & Bismarck & ND & 83,831 \\
\hline 7 & Bloomington-Normal & $\mathrm{IL}$ & 129,180 \\
\hline 8 & Battle Creek & MI & 135,982 \\
\hline 9 & Mansfield & $\mathrm{OH}$ & 126,137 \\
\hline 10 & Elmira & NY & 95,195 \\
\hline 11 & Boston & MA & $1,950,855$ \\
\hline 12 & Harrisburg-Lebanon-Carlisle & PA & 587,986 \\
\hline 13 & Altoona & PA & 130,542 \\
\hline 14 & Hagerstown & $\mathrm{MD}$ & 121,393 \\
\hline 15 & Washington & $\mathrm{DC}$ & $3,923,574$ \\
\hline 16 & Richmond-Petersburg & VA & 865,640 \\
\hline 17 & Danville & VA & 108,711 \\
\hline 18 & Fayetteville & $\mathrm{NC}$ & 274,566 \\
\hline 19 & Florence & $\mathrm{SC}$ & 114,344 \\
\hline 20 & Greenville-Spartanburg & $\mathrm{SC}$ & 640,861 \\
\hline 21 & Lexington-Fayette & KY & 348,428 \\
\hline 22 & Memphis & $\mathrm{TN}$ & 981,747 \\
\hline 23 & Decatur & $\mathrm{AL}$ & 131,556 \\
\hline 24 & Macon-Warner Robins & GA & 281,103 \\
\hline 25 & Lakeland-Winter Haven & FL & 405,382 \\
\hline 26 & Bradenton & FL & 211,707 \\
\hline 27 & Baton Rouge & LA & 528,264 \\
\hline 28 & Shreveport & LA & 334,341 \\
\hline 29 & Beaumont-Port Arthur & TX & 361,226 \\
\hline 30 & Bryan-College Station & TX & 121,862 \\
\hline
\end{tabular}

\section{Methodology}

I traveled by personal car to all 30 cities in the order shown in Table 3, starting in October 1997 and finishing in March 1998. I spent 2-5 days gathering data in each city, mostly by telephone from motel rooms. (Gathering data on urban wood wastes took most of this time; the time spent on waste grease data collection ranged from about two hours to about eight hours, depending on the size of the metropolitan area.) I was able to make use of local resources such as yellow pages, libraries, Chambers of Commerce, and government agencies. Spending time in each area helped provide an "on-the-ground" perspective to the study, including site visits and meetings with key waste managers, that hopefully created tangible benefits in the quality of the data and interpretation. The methodology used in this study can easily be replicated by myself or others, entirely by telephone and without personal visits. The availability of yellow pages and other resources on the Internet makes the initial step of obtaining names and numbers relatively easy and inexpensive. 
Table 4

Size Distributions: Sample of 30 and 281 US Metropolitan Areas

No. of metro areas with population:

$$
\begin{aligned}
& >1,000,000 \\
& 500,000-1,000,000 \\
& 200,000-500,000 \\
& 125,000-200,000 \\
& <125,000 \\
& \quad \text { Total }
\end{aligned}
$$

\begin{tabular}{|c|c|c|c|}
\hline $281 \mathrm{Me}$ & eas & \multicolumn{2}{|c|}{$\begin{array}{l}\text { Sample of } 30 \\
\text { Metro Areas }\end{array}$} \\
\hline 38 & $14 \%$ & 4 & $13 \%$ \\
\hline 37 & $13 \%$ & 5 & $17 \%$ \\
\hline 81 & $29 \%$ & 9 & $30 \%$ \\
\hline 68 & $24 \%$ & 6 & $20 \%$ \\
\hline 57 & $20 \%$ & 6 & $20 \%$ \\
\hline$\overline{281}$ & $\overline{100 \%}$ & 30 & $100 \%$ \\
\hline
\end{tabular}

Average population
686,860
565,410

Upon completion of data-gathering for each successive group of five metropolitan areas, I compiled all the data for those five cities into a report and submitted each report to the NREL Technical Monitor, Shaine Tyson. This allowed for feedback and redirection as the study proceeded, and made compilation of the final report and interpretation of the total package of results an easier task.

In each city, I started by making complete lists from the government pages and the yellow pages of every agency and company that appeared to be relevant: wastewater treatment plants, rendering companies, and grease trap pumping companies. I counted the number of restaurants listed in the yellow pages. I had developed a set of survey forms and questions, with different questions for different types of businesses or agencies (see Appendix B). These forms were useful as prompters, but I did not adhere to them strictly. I stated very briefly that I was collecting data on urban waste grease resources for the US Department of Energy, and then asked a simple lead-off question such as "What do you do with the material you pump from restaurant grease traps?" (to a grease trap pumping company manager). In most cases I was able to engage in a friendly conversation while obtaining whatever quantitative information the person could share.

Many waste grease collectors and processors do not keep records; rendering companies guard their data jealously; so it was often necessary to use estimation techniques. These factored estimates are clearly noted in the report on each metropolitan area in Section C. Immediately after each phone call, I performed calculations as necessary and developed my best estimate of each respondent's waste grease collection or processing rate. Later (sometimes two or three weeks later), when I prepared the draft report on each group of five metropolitan areas, I combined all of these estimates with other data I had obtained to produce the waste grease resource estimates for each metropolitan area. In this process, I also took into account the non-respondents. For example, I might have obtained useful information from three grease trap pumping companies out of five in a particular area, but the estimate I generated was for all five companies. When the estimates were completed for all 30 cities, I went back over the entire set, checking carefully for consistency of calculation methods and assumptions. Then I performed some statistical analysis on the complete set of data, as discussed in Section B. 


\section{B. OVERVIEW OF URBAN WASTE GREASE DATA}

\section{Urban Waste Grease Resources}

Tables 5 and 6 summarize the data collected on urban waste grease resources from 30 metropolitan areas in the US during the period from October 1997 to March 1998. Table 5 shows the data for each metropolitan area in pounds/year; Table 6 shows the same data on a per capita basis, in pounds/year/person. The numbers in front of the metropolitan areas represent the order in which the areas were visited, and correspond to the subsection numbers in Section C, the part of the report describing the metropolitan areas' waste grease resources. City names followed by dashes indicate that additional cities are included in the official name of the metropolitan area (e.g., Provo-Orem). As a shortcut in the following discussion, the word "city" is used interchangeably with "metropolitan area", even though this is not strictly correct.

\section{Statistical Analysis of the Data}

Appendix $\mathrm{C}$ presents a series of seven regression plots and statistical analyses. The first plot, restaurants vs. 1,000 population, confirms the observation that there is not much variability from one urban area to another in the number of restaurants per 1,000 people. Table 6 shows that the number is between 1 and 2 for all 30 cities, and usually in the middle of this range, with a weighted average of 1.41 restaurants $/ 1,000$ people. The regression plot shows that the best fit line has a coefficient (slope) of 1.36 restaurants/1,000 people, with an r-squared value of 0.985. Based on this finding, we would expect that the number of restaurants and the number of people in a metropolitan area give about the same ability to predict the quantities of waste grease resources in that area. The other six regression plots show that this is indeed the case, as summarized below:

\section{vs. Population}

Weighted average, pounds/year/person

Regression coefficient, $1 \mathrm{~b} / \mathrm{y} / \mathrm{p}$

R squared

vs. Number of Restaurants

$\begin{array}{llcc}\text { Weighted average, } \text { pounds/year/restaurant } & 6,268 & 9,453 & 16,325 \\ \text { Regression coefficient, lb/y/r } & 6,256 & 9,553 & 15,903 \\ \text { R squared } & 0.849 & 0.921 & 0.908\end{array}$

The population of a metropolitan area, state, or other geographic area is generally easier to obtain than the number of restaurants in that area. Rounding off to reflect a reasonable number of significant digits, the urban waste grease resources of a metropolitan area, region, state, or the US as a whole can be predicted from the following simple equations: 
- Yellow grease, pounds/year/person $=9$

- Trap grease, pounds/year/person $=13$

- Total waste grease, pounds/year/person $=22$

Table 5

Urban Waste Grease Resources in 30 Metropolitan Areas Pounds/Year

\begin{tabular}{|c|c|c|c|c|c|c|c|}
\hline 10 & Nictio Ane & & opulation & $\begin{array}{l}\text { No. of } \\
\text { Rstrnts } \\
\end{array}$ & $\begin{array}{l}\text { Yellow } \\
\text { Grease }\end{array}$ & $\begin{array}{c}\text { Trap } \\
\text { Grease } \\
\end{array}$ & $\begin{array}{c}\text { Total } \\
\text { Grease } \\
\end{array}$ \\
\hline 1 & Sacramento & $\mathrm{CA}$ & $1,481,102$ & 2,200 & $4,500,000$ & $\overline{16,600,000}$ & $\overline{21,100,000}$ \\
\hline 2 & Olympia & WA & 161,238 & 240 & $1,080,000$ & $1,200,000$ & $2,280,000$ \\
\hline 3 & Provo- & UT & 263,590 & 400 & $4,380,000$ & $7,000,000$ & 11,3 \\
\hline 4 & Denver- & $\mathrm{CO}$ & $1,848,319$ & 2,670 & $17,000,000$ & $15,900,000$ & $32,900,000$ \\
\hline 5 & Lincoln* & $\mathrm{NE}$ & 213,641 & 350 & $4,500,000$ & $2,600,000$ & $21,600,000$ \\
\hline 6 & & ND & & 133 & 430,000 & 400,000 & 830,000 \\
\hline 7 & gton- & IL & 129 & 200 & 500 & 2,30 & 2,80 \\
\hline 8 & Battle Creek & MI & 982 & 211 & $1,500,000$ & $1,50($ & $3,000,000$ \\
\hline 9 & Mans & $\mathrm{OH}$ & 126,137 & 244 & & & 00 \\
\hline 10 & Elmira & NY & & 140 & & 1,50 & 00 \\
\hline 11 & Bost & MA & $1,950,8$ & 3,000 & 10,400 & 33,60 & 44,00 \\
\hline 12 & & PA & & 900 & & 10 & 16, \\
\hline 13 & $\mathrm{Al}$ & $\mathrm{P}$ & & & & & \\
\hline 14 & $\mathrm{Ha}$ & $\mathrm{MD}$ & & & & & \\
\hline 15 & & $\mathrm{DC}$ & 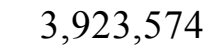 & 5,000 & 00 & 50,0 & 89,0 \\
\hline 16 & Ric & VA & & 1,480 & & 17,3 & 26,00 \\
\hline 17 & Dan & VA & & 157 & 00 & 1,90 & 000 \\
\hline 18 & & $\mathrm{NC}$ & & 384 & & & 000 \\
\hline 19 & Flor & $\mathrm{SC}$ & & 185 & & & 000 \\
\hline 20 & Gree & $\mathrm{SC}$ & & 1,017 & 6,40 & 4,60 & $11,000,000$ \\
\hline 21 & Lexi & KY & & 562 & & &, 000 \\
\hline 22 & Mer & $\mathrm{TN}$ & & 1,128 & 9,80 & 18,50 & $28,300,000$ \\
\hline 23 & Dec & $\mathrm{AL}$ & & 245 & 1,3 & 2,40 &, 000 \\
\hline 24 & & & & & 2,8 & & 8,7 \\
\hline 25 & & $\mathrm{~F}$ & & 445 & & & \\
\hline 26 & $\mathrm{Br}$ & $\mathrm{FI}$ & & 360 & & 3,0 & 00 \\
\hline 27 & & LA & & & & 5,80 & 11,1 \\
\hline 28 & & LA & & 442 & & 4,70 & $8,000,000$ \\
\hline 29 & Beaumont- & TX & 361,226 & 383 & $3,600,000$ & $3,900,000$ & $7,500,000$ \\
\hline 30 & Bryan- & TX & 121,862 & 198 & $1,200,000$ & $2,000,000$ & $3,200,000$ \\
\hline
\end{tabular}

*Lincoln total includes $14,500,000$ pounds/year of food plant waste grease. 
Table 6

Urban Waste Grease Resources in 30 Metropolitan Areas

Pounds/Year/Person

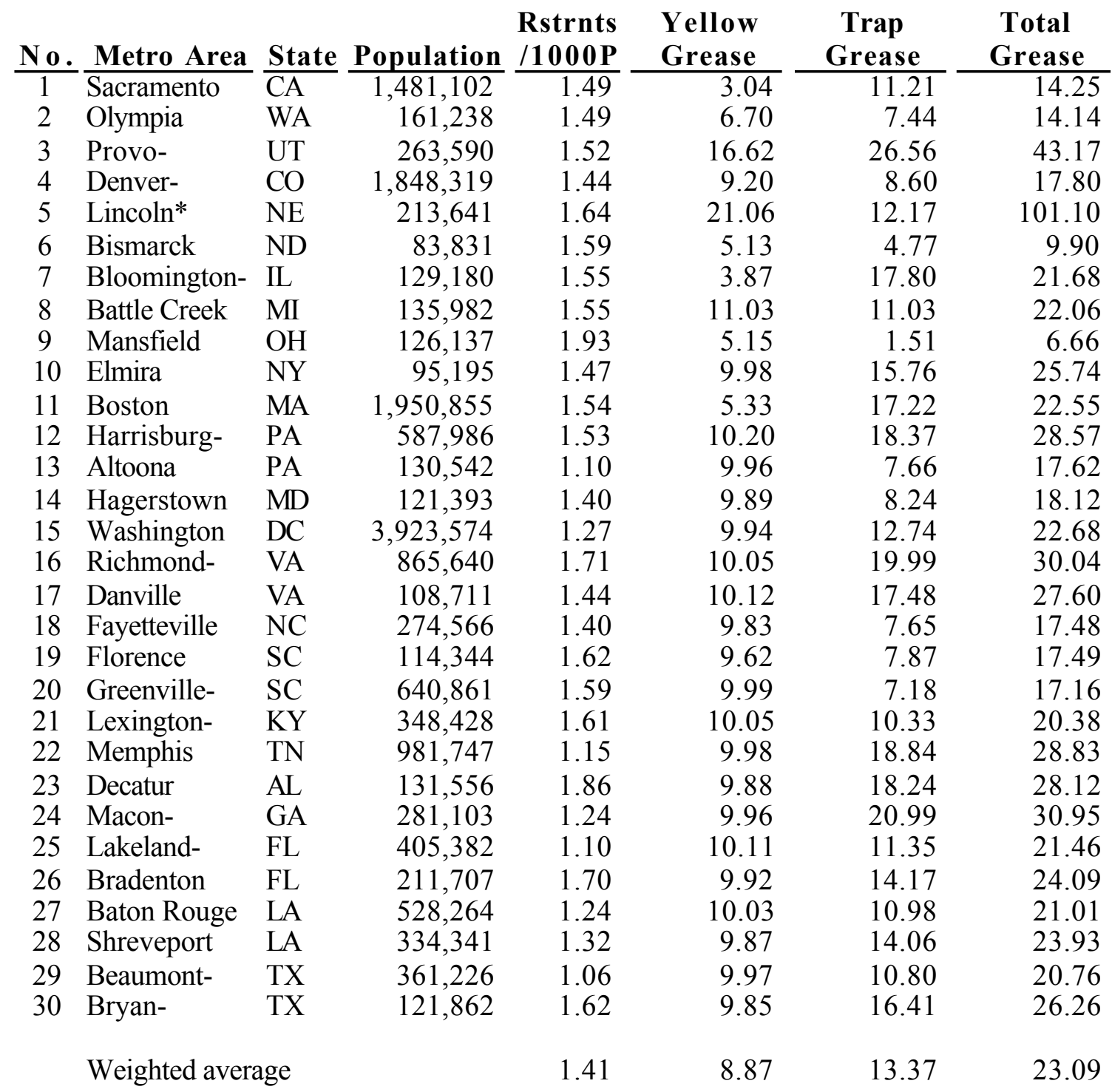

*Lincoln total includes 67.87 pounds/year/person of food plant waste grease.

It is important to note that the waste grease resource estimates in many of the metropolitan areas were not based on actual measured data. In the absence of measured data, I used factored estimates, which were based on measured data in other cities combined with the qualitative data and opinions obtained from local experts. As a result, the above predictive equations are really most representative of the small number of cities where measured data were available. If measured data had been obtained from all 30 of the cities, the variability in the data would probably be higher (greater scatter of data points on the regression plots, and smaller r-squared values). 


\section{METROPOLITAN AREA REPORTS}

\section{Sacramento, California}

Population (1990): 1,481,102

The Sacramento Yellow Pages list two rendering companies, 11 grease trap cleaning companies, and about 2,200 restaurants. Based on the information provided by the rendering companies, I estimate that about 4,500,000 pounds/year of grease are collected from Sacramento area restaurants for processing into yellow grease and subsequent blending into animal feed and other products. This amount of grease corresponds to about 2,000 pounds/year/restaurant, which is significantly lower than in other cities in the sample. This leads me to suspect that the estimate is low.

In Sacramento, as in other large cities, the business of picking up grease from restaurants is very competitive. Sacramento Rendering Company, which I believe has the largest market share in Sacramento, told me that at least four other companies compete with them. They are paying restaurants at least $1 \varnothing$ per pound of grease. Pilfering of grease containers is a problem from time to time (when commodity grease prices are high). Florin Tallow Company also services Sacramento restaurants and delivers grease to its parent company, the Modesto Tallow Company, which has a rendering plant in Modesto.

California regulations and ballot referenda are moving towards collection and processing of grease trap wastes by rendering companies instead of disposal in wastewater treatment plants. This trend will probably gain momentum nationwide during the next several years. Newer restaurants in some areas of California are required to install interceptors instead of traditional grease traps. An interceptor is a larger device that can be visualized as a wide spot in the line that allows cleaner grease to be recovered.

The Regional Sanitation District wastewater treatment plant (which services the city and county of Sacramento and the city of Folsom) currently receives most of the grease trap wastes in the Sacramento metropolitan area. The pump trucks drive to three different sites and discharge to manholes which provide a "straight shot" to the treatment plant. In effect, restaurant grease is prevented from flowing through the narrow drains and piping at the beginning of the collection system, but is reinjected into the main sewage stream near the treatment plant where the lines are wide and plugging is not a concern. The total amount of grease trap pump truck material received by the Regional Sanitation District in calendar year 1996 was 914,945 gallons, which at 7.3 pounds/gallon is about 6,700,000 pounds/year. Assuming the grease content of this material averages about $10 \%$ by weight, the estimated amount of grease collected from Sacramento area grease traps is about 670,000 pounds/year.

The Regional Sanitation District wastewater treatment plant receives an average of 157 million gallons/day of raw sewage. The oil and grease content in the raw sewage averages about 35 parts per million (ppm). This results in an estimate of about $16,600,000$ pounds/year of oil and grease entering the wastewater treatment plant. The 670,000 pounds/year of grease recovered from restaurant grease traps and discharged into the designated manholes is included in this number.

In summary, for Sacramento: 
Number of restaurants

Restaurants/1,000 people

Yellow grease

Grease trap waste

Total grease resource
2,200

\begin{tabular}{|c|c|c|}
\hline Pounds/year & Pounds/year/person & Pounds/year/restaurant \\
\hline 500 & 3.0 & 2,000 \\
\hline $16,600,000$ & 11.2 & 7,500 \\
\hline $21,100,000$ & 14.2 & 9,600 \\
\hline
\end{tabular}

2. Olympia, Washington

Population (1990): 161,238

The Olympia Yellow Pages list two rendering companies and one grease trap service company. There are approximately 240 restaurants in the Olympia metropolitan area. The general manager at Darling International, the rendering company with the largest market share in the Puget Sound area, suggested I use a factor of 200 pounds of grease per month per restaurant. I suspect this factor to be low based on information from other cities. The manager at Baker Commodities stated that his company had collected about 360,000 pounds/year from about 80 restaurants in Olympia (about 4,500 pounds/year/restaurant). I decided to use this factor for the total estimate, giving 1,080,000 pounds/year.

The grease trap company, which is a subsidiary of Baker Commodities, collects grease trap wastes from only about six restaurants in Olympia. These wastes are delivered to the Baker Commodities rendering plant for processing. Most of the restaurants in the area do not have grease traps. A laboratory employee at the Olympia Wastewater Treatment Plant told me that the plant received (through the sewer system) about 1,200,000 pounds of grease and oil in 1996. This estimate is based on gravimetric analyses performed on monthly grab samples of the raw sewage entering the plant.

In summary, for Olympia:

Number of restaurants

Restaurants/1,000 people

Yellow grease

Grease trap waste

Total grease resource
240

\begin{tabular}{|c|c|c|}
\hline Pounds/year & Pounds/year/person & Pounds/year/restaurant \\
\hline 1,08 & 6.7 & 4,500 \\
\hline $1,200,000$ & 7.4 & 5,000 \\
\hline $2,280,000$ & 14.1 & 9,500 \\
\hline
\end{tabular}

\section{Provo-Orem, Utah}

Population (1990): 263,590

The Provo-Orem Yellow Pages list two rendering companies, two grease trap service companies, and about 400 restaurants. Bonneville Livestock Inc. in Lehi collects and processes about 55-60\% of the restaurant grease in Utah, and also operates in four or five nearby states. Its manager described a competitive business, with John Kuhni \& Sons (the other company listed in the yellow pages), American Commodities Co., and Renegade Oil Co. all vying for restaurant accounts in the Provo-Orem area. The manager at John Kuhni \& Sons stated that Renegade Oil Co. in Salt Lake City is his biggest competitor. In the Provo-Orem area, John Kuhni \& Sons picks up, on average, about two barrels every three weeks from about 70-75 restaurants. Assuming an average of 300 pounds of grease per barrel, this is equivalent to about 30 pounds/day/restaurant. Using this data point, I estimate that the total amount of yellow grease feedstock generated by the 400 restaurants in the Provo-Orem metropolitan area is about 4,380,000 pounds/year. 
Both grease trap service companies provided estimates of their grease trap wastes from the Provo-Orem area, which total about 3,000,000 pounds/year. All grease trap wastes in the Salt Lake City-Provo-Orem area are delivered to ET Technologies, a soils regeneration operation in Salt Lake City. At this facility, oily wastes and greases are bioremediated using microbes and nutrients. Materials are blended and composted; the product is used as topsoil for the final cover on closed landfill sites. The manager of this facility estimated that it receives about 600 tons/month $(14,400,000$ pounds/year) of raw material from tank trucks that is a mixture of oils and greases, food wastes and other garbage, and water. Assuming that Provo-Orem generates about $20 \%$ of this material (based on population), this estimate comes out very close to the $3,000,000$ pounds/year estimated by the grease trap service companies. However, both the ET Technologies manager and one of the grease trap service company representatives stated that only about $10 \%$ of this mixture is usable oils and greases that could be processed by rendering companies (or by biodiesel plants). On this basis I reduced the estimate of the amount of grease being recovered from Provo-Orem restaurant grease traps to 300,000 pounds/year.

Not all of the restaurants in the Provo-Orem area have grease traps; in addition, there are some industrial (e.g., food processing) facilities that discharge grease and oily wastes to the sewage system. There are three wastewater treatment plants in the Provo-Orem metropolitan area: the Provo Sewage Treatment Plant, the Orem Sewage Treatment Plant, and the Timpanogis Special Service District in American Fork, which serves nine small cities and towns north of Orem.

The Provo plant receives about 45,000,000 gallons/day of total influent. Weekly grab samples of the raw sewage contain an average of about 45 milligrams/liter of grease and oil. This is equivalent to 0.000376 pounds/gallon, and produces an estimate of about $5,480,000$ pounds/year of oil and grease entering the Provo sewage treatment plant.

The Orem plant receives about 9,500,000 gallons/day of total influent. Weekly grab samples of the raw sewage contain 13-22 milligrams/liter of grease and oil. Using the midpoint of this range (which is equivalent to 0.000146 pounds/gallon) produces an estimate of about 506,000 pounds/year of oil and grease entering the Orem sewage treatment plant.

The Timpanogis plant receives about 10,500,000 gallons/day of total influent, of which about 7\% is from "industrial" sources including restaurants. Weekly grab samples of the raw sewage contain 20-25 milligrams/liter of grease and oil. Using the midpoint of this range (which is equivalent to 0.000188 pounds/gallon) produces an estimate of about 720,000 pounds/year of oil and grease entering the Timpanogis Special Service District sewage treatment plant. The grand total for the three sewage plants in the Provo-Orem metropolitan area is about $6,700,000$ pounds/year of grease and oil.

In summary, for Provo-Orem:

Number of restaurants

Restaurants/1,000 people

Yellow grease

Grease trap waste

Total grease resource
400

1.52

\begin{tabular}{|c|c|c|}
\hline Pounds/year & Pounds/year/person & Pounds/year/restaurant \\
\hline $4,380,000$ & 16.6 & 11,000 \\
\hline $7,000,000$ & 26.6 & 17,500 \\
\hline $11,380,000$ & 43.2 & 28,500 \\
\hline
\end{tabular}


The Denver-Boulder Yellow Pages list 2,670 restaurants, six rendering companies (one of which now owns one of the others, and another of which processes animal carcasses only), and 13 grease trap service companies. National Byproducts, Inc., which recently acquired Colorado Grease Company, appears to have the largest market share of the rendering companies serving the Denver-Boulder area. They pay some restaurants for grease, and do not pay some others (depending on volume and location). National has eight rendering plants in the mid-continent area, and provides bulk containers to its large customers (approximately $5 \times 3 \times 3$ feet) which get emptied into the collection trucks, instead of exchanging 55-gallon drums as most of the rendering companies do. National's manager estimated that the total amount of grease generated by Denver-Boulder restaurants is 300,000-350,000 pounds/week, of which his company picks up about 200,000-250,000 pounds/week. Discussions with the other rendering companies reinforced these estimates. I used the midrange of National By-Products' estimate to arrive at the total estimate of $17,000,000$ pounds/year of yellow grease generated by Denver-Boulder restaurants.

Discussions with the Denver-Boulder grease trap service companies did not produce meaningful resource estimates, but did indicate that all of these companies haul the grease trap wastes to the Denver Metropolitan Wastewater Treatment Plant. A laboratory employee at the wastewater treatment plant reported that 3,531,000 gallons of grease trap wastes were delivered to the plant in calendar year 1996 (versus about 3,700,000 gallons in 1995). She stated that the tank truck drivers do not mix grease trap wastes with other wastes (such as septic) and that her number is based on summing the numbers each driver reports when the wastes are discharged at the plant. She also stated that this number includes grease wastes from food processing plants as well as restaurants, but did not know the relative amounts of each. Assuming 7.3 pounds/gallon for the density of this material and assuming that about $10 \%$ of the material is grease, the estimated amount of grease containted in grease trap wastes in Denver-Boulder is about 2,580,000 pounds/year.

The Denver Metropolitan Wastewater Treatment Plant receives an average of 150 million gallons/day of raw sewage. The oil and grease content in the raw sewage averages about $35 \mathrm{ppm}$. This results in an estimate of about 15,900,000 pounds/year of oil and grease entering the wastewater treatment plant. The 2,580,000 pounds/year of grease recovered from restaurant grease traps and discharged at the wastewater treatment plant is included in this number.

In summary, for Denver-Boulder:

Number of restaurants

Restaurants/1,000 people

Yellow grease

Grease trap waste

Total grease resource
2,670

1.44

\begin{tabular}{|c|c|c|}
\hline Pounds/year & Pounds/year/person & Pounds/year/restaurant \\
\hline 17 & 9.2 & 6,400 \\
\hline $15,900,000$ & 8.6 & 6,000 \\
\hline $32,900,000$ & 17.8 & 12,300 \\
\hline
\end{tabular}

\section{Lincoln, Nebraska}

Population (1990): 213,641

The Lincoln Yellow Pages list 350 restaurants, two rendering companies, and one grease trap pumping company. A manager at Darling International, a major rendering company with nationwide operations, provided a fairly complete picture of the restaurant grease recovery business in Lincoln. He estimated that Darling International and General Grease each recover about $40 \%$ of the total restaurant grease, and that National Byproducts 
recovers the other $20 \%$. He believes the total amount of grease recovered from Lincoln area restaurants is about 4-5 million pounds/year. I used an estimate of 4,500,000 pounds/year.

One of the two wastewater treatment plants in Lincoln, the Theresa Street Treatment Plant, receives all of the grease trap wastes collected in the metropolitan area. This material is fed to anaerobic digesters at the treatment plant. The laboratory manager at the treatment plant provided the following figures for calendar year 1996:

- Restaurant grease traps -- 1,218 tank truck loads totaling 629,925 gallons. Assuming 7.3 pounds/gallon and $10 \%$ grease content, this material contains about 460,000 pounds/year of grease.

- ADM soybean processing plant waste grease -- 266 tank truck loads totaling 733,200 gallons, which converts to about 5,400,000 pounds/year (dilution factor unknown).

- Cook Foods plant (ham, bacon) -- 624 tank truck loads totaling 1,243,400 gallons, which converts to about 9,100,000 pounds/year (dilution factor unknown).

The two wastewater treatment plants in Lincoln receive a total of about 20 million gallons/day of raw sewage. The oil and grease content in the raw sewage averages about $35 \mathrm{ppm}$. This results in an estimate of about 2,100,000 pounds/year of oil and grease entering the wastewater treatment plants. The grease recovered from restaurant grease traps and food processing plants and discharged at the Theresa Street treatment plant is not included in this number.

In summary, for Lincoln:

Number of restaurants

Restaurants/1,000 people

Yellow grease

Grease trap waste

Subtotal

Food processing plants

Total grease resource

\begin{tabular}{|c|c|c|}
\hline Pounds/year & Pounds/year/person & Pounds/year/restaurant \\
\hline $4,500,000$ & 21.1 & 12,900 \\
\hline $2,600,000$ & 12.2 & 7,400 \\
\hline $7,100,000$ & 33.2 & 20,300 \\
\hline
\end{tabular}

$14,500,000$

$21,600,000$

\section{Bismarck, North Dakota}

Population (1990): 83,831

The Bismarck-Mandan Yellow Pages list 133 restaurants, four rendering companies, and one grease trap pumping company. One rendering company, located about 60 miles west of Bismarck, estimated that they recover about 260,000 pounds/year of yellow grease feedstock from Bismarck area restaurants, and that they have about a $60 \%$ market share. Assuming these estimates are accurate, the total amount of yellow grease feedstock being recovered from Bismarck area restaurants is about 430,000 pounds/year.

The Bismarck wastewater treatment plant reported that it had been many years since an analysis of grease in the raw sewage had been performed. The plant receives about 6.5 million gallons/day of raw sewage. Hydrosieve screens in the pretreatment facility remove the large grease balls (which contain many materials other than restaurant grease); this material is landfilled. Smaller grease particles coagulate on the primary clarifiers and are treated by aeration in the oil/grease pit. The plant manager estimated that perhaps 300 gallons/day enter the pit, of which maybe 75 gallons/day are grease. Adding another 25 
gallons/day for grease balls, this results in a very rough estimate of 270,000 pounds/year of grease entering the Bismarck sewage treatment plant.

The Mandan wastewater treatment plant receives about 1.8 million gallons/day of raw sewage. No estimate was available of the quantity of grease entering the plant. Ratioing from the Bismarck plant results in an estimate of about 80,000 pounds/year of grease entering the Mandan sewage treatment plant.

The grease trap pumping companies in the Bismarck area apparently take the material to the landfills. My very rough estimate of the total quantity of grease trap waste disposed of in the Bismarck metropolitan area is 50,000 pounds/year. Adding this to the amounts estimated for the two sewage treatment plants results in a total estimate of 400,000 pounds/year of grease trap waste.

In summary, for Bismarck:

Number of restaurants

Restaurants/1,000 people

Yellow grease

Grease trap waste

Total grease resource
133

1.59

\begin{tabular}{|c|c|c|}
\hline Pounds/year & Pounds/year/person & Pounds/year/restaurant \\
\hline 430,000 & 5.1 & 3,200 \\
\hline 400,000 & 4.8 & 3,000 \\
\hline 830,000 & 9.9 & 6,200 \\
\hline
\end{tabular}

\section{Bloomington-Normal, Illinois}

Population (1990): 129,180

The Bloomington-Normal Yellow Pages list 200 restaurants, no rendering companies, and one grease collection service that turned out to be a rendering company in Joliet (about 80 miles northeast of Bloomington). The rendering company estimated that they recover about 500,000 pounds/year of yellow grease feedstock from Bloomington-Normal area restaurants, and that they have close to a $100 \%$ market share.

The Bloomington-Normal Water Reclamation District wastewater treatment plant reported that they process about 20 million gallons/day of raw sewage, and that the grease and oil content is well below 100 parts per million. I assumed $35 \mathrm{ppm}$, which results in an estimate of 2,100,000 pounds/year of grease entering the sewage plant with the raw sewage. In addition, about 150 grease trap pumping trucks per year discharge their contents (assumed to average 1,500 gallons each) to the wastewater treatment plant's anaerobic digesters. At 7.3 pounds/gallon and a 10\% grease content, this results in an estimated total of 160,000 pounds/year of grease trap pumping waste. Adding this to the amount estimated for the sewage treatment plant influent results in a total estimate of $2,300,000$ pounds/year of grease trap waste.

In summary, for Bloomington-Normal:

Number of restaurants

Restaurants/1,000 people

Yellow grease

Grease trap waste

Total grease resource
200

1.55

\begin{tabular}{|c|c|c|}
\hline Pounds/year & Pounds/year/person & Pounds/year/restaurant \\
\hline 500,000 & 3.9 & 2,500 \\
\hline $2,300,000$ & 17.8 & 11,500 \\
\hline $2,800,000$ & 21.7 & 14,000 \\
\hline
\end{tabular}


The Battle Creek Yellow Pages list 211 restaurants, no rendering companies, and 13 septic tank cleaning companies. The municipal wastewater treating plant receives about 12 million gallons of raw sewage per day containing "less than $100 \mathrm{ppm}$ " of grease and oil. Based on data from other cities, I assumed a concentration of $35 \mathrm{ppm}$, which results in an estimate of about 1,300,000 pounds/year of grease entering the wastewater treatment plant with the raw sewage. The wastewater treatment plant does not allow grease trucks or septic tank trucks to discharge there.

Roto Rooter in Kalamazoo was the only company I found that acknowledged pumping grease traps in the Battle Creek area. They have a processing facility in Kalamazoo, and take the resulting solid waste material to a landfill. My guesstimate of the total amount of grease trap waste pumped from Battle Creek restaurants is about 200,000 pounds/year, bringing the total estimate for grease trap waste plus grease entering the sewage plant to $1,500,000$ pounds/year.

I was unable to get any useful information directly from the rendering companies that pick up most of the waste grease from Battle Creek restaurants, which I believe to be Cedar Creek Rendering in Grand Rapids, MI, Krueger Commodities in Hamilton, MI, and Darling International in Detroit. The manager at Darling International told me that the company with the largest market share in Battle Creek is Krueger Commodities (who did not return my calls). The Darling manager gave me data from the Detroit metropolitan area, which translates to 11.1 pounds of yellow grease feedstock per year per person. I used this figure as a basis for estimating the yellow grease resource in Battle Creek: 11.1 pounds/year/person is equivalent to about 1,500,000 pounds/year of yellow grease.

In summary, for Battle Creek:

Number of restaurants

211

Restaurants/1,000 people

1.55

Yellow grease

Grease trap waste

Pounds/year

Total grease resource

$1,500,000$
$1,500,000$
$3,000,000$

Pounds/year/person

Pounds/year/restaurant

11.0

11.0

7,100

22.1

7,100

14,200

\section{Mansfield, Ohio}

Population (1990): 126,137

The Mansfield Yellow Pages list 244 restaurants, no rendering companies, and several septic tank cleaning companies. The municipal wastewater treating plant receives about 10 million gallons of raw sewage per day which contains 4-5 ppm of grease and oil, based on grab samples analyzed twice a week. This results in an estimate of about 150,000 pounds/year of grease entering the wastewater treatment plant with the raw sewage.

From the local McDonald's business office I learned that GA Windsor of Wapakoneta, Ohio (west of Mansfield, near Lima) picks up grease and pumps grease traps in the Mansfield area. A manager at GA Windsor estimated that they have about a $65 \%$ market share in Mansfield, and that they recover about 35,000 pounds of yellow grease per month from Mansfield area restaurants. This translates to a total yellow grease estimate for Mansfield of about 650,000 pounds/year.

GA Windsor also pumps grease traps. They refine the material and extract the usable grease from it. Based on the information I obtained from GA Windsor, I estimate that 
about 37,000 pounds/year of grease is recovered from grease trap wastes pumped from Mansfield area restaurants. Combining this estimate with the 150,000 pounds/year entering the wastewater treatment plant gives a total estimate of about 190,000 pounds/year for grease trap waste either being recovered or entering the wastewater treatment plant.

In summary, for Mansfield:

Number of restaurants

Restaurants/1,000 people

Yellow grease

Grease trap waste

Total grease resource
244

1.93

\begin{tabular}{|c|c|c|}
\hline Pounds/year & Pounds/year/person & Pounds/year/restaurant \\
\hline 650,000 & 5.2 & 2,700 \\
\hline 190,000 & 1.5 & 800 \\
\hline 840,000 & 6.7 & 3,400 \\
\hline
\end{tabular}

\section{Elmira, New York}

Population (1990): 95,195

The Elmira Yellow Pages list 140 restaurants, two rendering companies, and one grease trap pumping company. Neither rendering company manager returned my calls. I estimate the yellow grease resource in Elmira to be similar to those in Michigan and Ohio on a per capita basis (11.1 pounds/year/person in Battle Creek and 5.1 pounds/year/person in Mansfield). Assuming a value of 10 pounds/year/person in Elmira gives an estimate of about 950,000 pounds/year.

There are two wastewater treatment plants in the Elmira area. Plant \#1 in Horseheads receives about 6 million gallons/day of raw sewage, and the "Southside" plant in Elmira receives about 8 million gallons/day. Neither plant measures the grease content in the raw sewage. "Greaseballs" are removed at the screens and clarifiers, and disposed of at the landfill. Neither wastewater treatment plant allows grease trap pump trucks to discharge their wastes at the treatment plant. Grease trap pumping companies are supposed to dispose of their wastes privately. Because the grease trap company manager did not return my calls, I was unable to find out either how much grease trap waste his company removes from Elmira area restaurants, or where they dispose of it.

My estimate for grease trap wastes for Elmira, like the yellow grease estimate, is based on data from other cities. Assuming the raw sewage to the wastewater treatment plants contains about 35 parts per million grease, then the total amount of grease entering the two wastewater treatment plants in the Elmira area is about 1,500,000 pounds/year. Combining this estimate with an estimate of 30,000 pounds/year removed from restaurant grease traps gives a total estimate of 1,500,000 pounds/year for grease trap waste either being disposed of or entering the wastewater treatment plants.

In summary, for Elmira:

Number of restaurants

Restaurants/1,000 people

Yellow grease

Grease trap waste

Total grease resource
140

1.47

\begin{tabular}{|c|c|c|}
\hline Pounds/year & Pounds/year/person & Pounds/year/restaurant \\
\hline 950,000 & 10.0 & 6,800 \\
\hline $1,500,000$ & 15.8 & 10,700 \\
\hline $2,450,000$ & 25.7 & 17,500 \\
\hline
\end{tabular}


The Boston Area Yellow Pages list about 2,700 restaurants, three rendering companies, and nine grease trap pumping companies. An official in the Enforcement Division of the Boston Water \& Sewer Commission said that they "enforce" grease trap pumping standards on about 1,500-1,600 restaurants, and that there are probably 3,000-4,000 restaurants in the metropolitan area. Typically they require pumping of grease traps about once a week. Grease trap pumping companies are not allowed to discharge to the regional wastewater treatment plants.

Two regional wastewater treatment plants in Boston Harbor handle essentially all of the wastewater from the metropolitan area. One of these plants, Nut Island, is closing, and the entire flow of about 280-300 million gallons/day will soon be going to the Deer Island plant. Based on an average of about 35 parts per million grease in the raw influent to the wastewater treatment plants, about 30,000,000 pounds of grease per year enter the Boston area wastewater treatment plants.

Based on discussions with the rendering companies, the approximate market shares in the Boston area are about 50\% for Baker Commodities (who has a rendering plant in North Bellerica, MA); $30 \%$ for A. Martucci \& Sons (who has a rendering plant in Tewksbury, MA); and $20 \%$ for American By-Products. The total amount of yellow grease feedstock recovered from Boston area restaurants is estimated to be about 10,400,000 pounds/year.

Only a couple of the grease trap pumping companies provided useful information. One of them discharges its material at a company named Mass Environmental in Carver, Massachusetts. They pay tipping fees of $\$ 0.11 /$ gallon for grease trap waste, and $\$ 0.06 /$ gallon for septage. The manager at Mass Environmental did not return my calls. I was told that there are several other facilities in the Boston metropolitan area that process grease trap wastes, but I did not get their names or numbers.

Stewart Septic Service Inc. estimates that it pumps about 20,000 gallons/day from grease traps in the region from Rhode Island to New Hampshire. They treat the material at their own facility in Lawrence, Massachusetts, recovering the grease and landfilling the rest. It seems likely that about $1 / 3$ of this material comes from the Boston metropolitan area, which would be about 18 million pounds/year of grease trap waste. My guess is that Stewart Septic Service probably has at least a 50\% market share of the restaurant grease trap pumping business in the Boston metropolitan area. Assuming 50\%, this implies that the total amount of grease trap waste pumped in the Boston metropolitan area is about 36 million pounds/year, containing about $10 \%$ grease, or about $3,600,000$ pounds/year.

In summary, for Boston:

Number of restaurants

Restaurants/1,000 people

1.54

Yellow grease

Grease trap waste

Pounds/year

Pounds/year/person

Pounds/year/restaurant

Total grease resource

$10,400,000$

$33,600,000$

5.3

17.2

22.6

3,500

11,200

14,700

12. Harrisburg-Lebanon-Carlisle, PA

Population (1990): 587,986

The Harrisburg Yellow Pages list about 550 restaurants, two rendering companies (Mopac and Valley Proteins Inc.), and four septic tank pumping companies that mentioned grease 
traps in their ads. I suspect the number of restaurants in the Harrisburg-Lebanon-Carlisle metropolitan area is probably closer to 900 , or roughly 1.5 restaurants per capita (which is a fairly consistent number in nearly all of the cities I have sampled). I did not actually obtain phone books from Lebanon or Carlisle, and although many restaurants in these cities were listed in the Harrisburg phone book, I suspect many were also not included. I have used an estimate of 900 restaurants in the calculations below.

Neither rendering company manager returned my calls. A manager of a septic tank pumping company told me that Mopac definitely has the largest share of the restaurant grease recovery market in the area. I estimate the yellow grease resource in Harrisburg to be similar to those in Michigan and Ohio on a per capita basis (11.1 pounds/year/person in Battle Creek and 5.1 pounds/year/person in Mansfield). Assuming a value of 10 pounds/year/person in Harrisburg gives an estimate of about 6,000,000 pounds/year.

The one septic tank (grease trap) pumping company manager who was willing to talk to me said his company dewaters the material pumped from restaurant grease traps in a plate and frame filter press and hauls the grease cake to the Harrisburg Refuse Incinerator. They used to discharge their pumping trucks at the wastewater treatment plant, but the plant stopped accepting grease. I did not receive any quantitative estimates, but this manager told me I could get a ballpark estimate by assuming that most restaurants in the area have a 1,000 gallon grease interceptor that is pumped roughly once a month, thus producing about 12,000 gallons per year of sludge that contains roughly 10 weight percent grease. Using those assumptions, I estimate that grease trap pumping companies in the Harrisburg area recover (and then dispose of by incineration) about 9,000,000 pounds/year of grease.

The Harrisburg wastewater treatment plant receives about 20-22 million gallons/day of raw sewage, which contains about 15-40 parts per million grease based on grab sample analyses. Using the middle of both of these ranges, I estimate that about $1,800,000$ pounds/year of grease enter the Harrisburg wastewater treatment plant along with the raw sewage.

In summary, for Harrisburg-Lebanon-Carlisle:

\begin{tabular}{lccccc} 
Number of restaurants & 900 & & & \\
Restaurants/1,000 people & $\begin{array}{c}1.52 \\
\text { Pounds/year }\end{array}$ & & Pounds/year/person & & Pounds/year/restaurant \\
\cline { 2 - 2 } Yellow grease & $6,000,000$ & & 10.2 & 6,700 \\
Grease trap waste & $10,800,000$ & & 18.4 & 12,000 \\
Total grease resource & $16,800,000$ & & 28.6 &
\end{tabular}

\section{Altoona, Pennsylvania}

Population (1990): 130,542

The Altoona Yellow Pages list about 143 restaurants, no rendering companies, and 6 septic tank pumping companies, none of which mentioned grease traps in their ads. The septic tank companies said that they do not pump grease traps.

Altoona has two sewage treatment plants, the East and West plants. I got essentially all the useful information about restaurant grease in the Altoona area from the plants' pretreatment coordinator. The West plant has an average flow of 7.3 million gallons/day, and receives virtually all of the restaurant grease, which is pretreated by placing bacteria in several manholes. (The East plant has an average flow of about 6.2 million gallons/day, mostly from industrial sources such as Conrail and the hospital.) The concentration of grease in the West plant's raw sewage averages about 50 parts per million. From this I estimated 
that about 1,000,000 pounds/year of grease from Altoona restaurants enter the sewage treatment plant.

About eight restaurants in Altoona have large (1,000-2,000 gallon) grease interceptors. (The ones mentioned were Olive Garden, Red Lobster, TGI Friday's, Chi Chi's, and McDonald's.) A septic tank cleaning company from Laretto, PA (not listed in the Altoona Yellow Pages) has a contract to haul the contents of these grease traps to the Ebensburg Sewage Treatment Plant. The sludge is dewatered at the treatment plant and landfilled. The amount pumped from these large grease traps averages about 2,000 gallons/month, or about 20,000 pounds/year of grease (assuming about 10\% grease in the slurry). The other restaurants, which have smaller grease traps (45-50 gallon), apparently dispose of their contents with the garbage. Based on this information, I believe it is reasonable to assume that almost all of the grease trap waste ends up in the West Sewage Treatment Plant and is included in the 1,000,000 pound/year estimate discussed above.

I learned from the pretreatment manager that Valley Proteins and Inland Products are the rendering companies that pick up yellow grease from restaurants in Altoona. These companies did not give me any useful information. I estimate the yellow grease resource in Altoona to be similar to those in Michigan and Ohio on a per capita basis (11.1 pounds/year/person in Battle Creek and 5.1 pounds/year/person in Mansfield). Assuming a value of 10 pounds/year/person in Altoona gives an estimate of about $1,300,000$ pounds/year.

In summary, for Altoona:

Number of restaurants

Restaurants/1,000 people

143

1.10

\begin{tabular}{|c|c|c|}
\hline Pounds/year & Pounds/year/person & Pounds/year/restaurant \\
\hline $1,300,00$ & 10.0 & 9,100 \\
\hline $1,000,000$ & 7.7 & 7,000 \\
\hline $2,300,000$ & 17.6 & 16,100 \\
\hline
\end{tabular}

Yellow grease

Grease trap waste

7.7

16,100

Total grease resource

\section{Hagerstown, Maryland}

Population (1990): 121,393

The Hagerstown Yellow Pages list about 170 restaurants, no rendering companies, and 6 septic tank pumping companies, none of which mentioned grease traps in their ads. Most of the septic tank companies said that they do not pump grease traps; the one that acknowledged pumping restaurant grease traps said he takes the material to the Conipagig Wastewater Treatment Plant in Williamsport, which treats rural Washington County's sewage. However, the Conipagig plant manager said they do not accept grease trap waste. He said Washington County does not have a place to legally dispose of grease trap waste, since a law was passed in 1992. He believes the material gets hauled to West Virginia.

The Hagerstown Water Pollution Control Plant has an average flow of about 7 million gallons/day. The plant does not allow grease trap wastes to be discharged there. The concentration of grease in the plant's raw sewage ranges from 40 to 70 parts per million and averages about 50 parts per million. From this I estimated that about $1,000,000$ pounds/year of grease from Hagerstown restaurants enter the sewage treatment plant.

I did not get information on rendering companies that service restaurants in Hagerstown. I estimate the yellow grease resource in Hagerstown to be similar to those in Michigan and Ohio on a per capita basis (11.1 pounds/year/person in Battle Creek and 5.1 
pounds/year/person in Mansfield). Assuming a value of 10 pounds/year/person in Hagerstown gives an estimate of about 1,200,000 pounds/year.

In summary, for Hagerstown:

Number of restaurants

Restaurants/1,000 people

Yellow grease

Grease trap waste

Total grease resource

\begin{tabular}{c}
170 \\
1.40 \\
Pounds/year \\
\hline $1,200,000$ \\
$1,000,000$ \\
$2,200,000$
\end{tabular}

\begin{tabular}{c} 
Pounds/year/person \\
\hline 9.9 \\
8.2 \\
18.1
\end{tabular}

\begin{tabular}{c} 
Pounds/year/restaurant \\
\hline 7,100 \\
5,900 \\
12,900
\end{tabular}

\section{Washington, DC}

Population (1990): 3,923,574

The Northern Virginia Yellow Pages list about 2,000 restaurants in the Washington, DC metropolitan area, one rendering company, and 60 septic tank pumping companies. It is likely that the true number of restaurants in the metropolitan area is 2 or 3 times this number, but I was unable to find a convenient way to confirm this. The 682 restaurants in Arlington (see below) translate to a much higher per capita figure than usual. I will use an estimated figure of 5,000 restaurants in the calculations below for lack of a better one; it is equivalent to about 1.27 restaurants per 1,000 people in the metropolitan area.

The one rendering company listed, Valley Proteins Inc., did not return my phone calls. It is headquartered in Winchester, Virginia, and I learned that it has a rendering plant in the Baltimore area. My guess is that this plant, and possibly another Valley Proteins plant in Virginia, process a large fraction of the restaurant grease from the Washington, DC area, but I was unable to obtain any estimates and had to resort to a factored estimate. Assuming a value of 10 pounds/year/person in the Washington, DC metropolitan area gives an estimate of about $39,000,000$ pounds/year.

The five septic tank pumping companies I was able to talk to said they do not pump restaurant grease traps. I learned from wastewater treatment plant pretreatment coordinators that some wastewater treatment plants in the metropolitan area do not allow trucks to discharge grease trap material, while others do. I believe most of this material is accounted for in the treatment plant influent numbers discussed below.

All of the municipal wastewater in the District of Columbia, and nearly all of the municipal wastewater in Montgomery County, is treated at the Blue Plains Wastewater Treatment Plant in Washington, DC. The total flow is about 350 million gallons per day, of which about half comes from DC and half from Montgomery County. There are two small wastewater treatment plants in Montgomery County: the Seneca plant (about 4.7 million gallons/day), and the Damascus plant (about 0.7 million gallons/day). In Prince George's County there are three wastewater treatment plants: Parkway, near Laurel (about 6.1 million gallons/day); Western Branch, in Upper Marlboro (about 17 million gallons/day); and Piscataway (about 22 million gallons/day). A manager at the Washington Suburban Sanitary Commission in Landover, Maryland gave me information on these operations, including the oil and grease concentrations measured in monthly grab samples at all five plants in Maryland. Although individual measurements ranged from 1.2 to $206 \mathrm{mg} / \mathrm{liter}$, the annual average concentrations for all five plants fell in the range of 27 to $38 \mathrm{mg} /$ liter. It appears from these data that $35 \mathrm{mg} /$ liter is a good assumption for the oil and grease concentration in the raw sewage in DC and its Maryland suburbs. The total flow rate is about 400 million gallons/day, which results in an estimate of about $42,000,000$ 
pounds/year of grease entering the wastewater treatment plants in the District of Columbia, Montgomery County, and Prince George's County.

Material pumped from restaurant interceptors (large capacity grease traps) can be discharged at Muddy Branch in upper Montgomery County; it ends up in the Blue Plains treatment plant. Material pumped from smaller grease traps is put in barrels and taken to rendering plants for processing.

The Arlington County wastewater treatment plant averages about 30 million gallons/day of raw sewage from the city of Arlington, parts of Alexandria, Crystal City, parts of Falls Church, and Fairfax City. The pretreatment coordinator said that the number of residents in this area is approximately 170,000; the daytime population is about 250,000; and that there are at least 682 restaurants in the area. (These figures translate to about 4.0 restaurants per 1,000 residents, or about 2.7 restaurants per 1,000 daytime population.)

Detailed studies by the Arlington County wastewater treatment plant pretreatment coordinator in 1991-1993 showed that the weighted average concentration of oil and grease in the effluent from the interceptors of all restaurants sampled was $295 \mathrm{mg} / \mathrm{liter}$ (note that in water, which weighs 1,000 grams/liter, $\mathrm{mg} /$ liter are equivalent to parts per million or ppm by weight). The effluent from one Chinese restaurant contained less than $1 \mathrm{mg} / \mathrm{liter}$ oil and grease. The plant regulates restaurants on an individual basis and limits their effluent to a maximum of $399 \mathrm{mg} /$ liter, based on the mean and standard deviation of sample analyses. I estimate the oil and grease concentration in the Arlington County wastewater treatment plant to be $35 \mathrm{mg} /$ liter, the weighted average for the five plants in the Maryland suburbs. With the estimated total raw sewage flow rate of 30 million gallons/day, this gives an estimate of about 3,200,000 pounds/year of grease entering the Arlington County wastewater treatment plant in the raw sewage.

The Arlington County wastewater treatment plant does not allow grease trap pumping trucks to discharge their wastes at the plant. The pretreatment coordinator said that other wastewater treatment plants in the area may accept this material, and that the Valley Proteins rendering plant in Baltimore does accept it.

The Fairfax County Lower Potomac wastewater treatment plant in Lorton averages about 45 million gallons/day of total raw sewage influent. The plant prohibits restaurants from discharging oil and grease through the sewage system to the plant. All oil and grease delivered to the facility is burned in the furnace along with natural gas (the primary fuel) and landfill gas (this operation is just starting). The wastewater treatment plant does not measure oil and grease in its influent. My estimate is that the concentration is similar to that in other plants in the area, $35 \mathrm{mg} /$ liter. Assuming this results in an estimate of about 4,800,000 pounds/year of grease entering the Fairfax County Lower Potomac wastewater treatment plant in the raw sewage. Adding the two Virginia county estimates to the DC and Maryland county estimates gives a total estimate for the Washington, DC metropolitan area of 50,000,000 pounds/year of grease entering wastewater treatment plants.

In summary, for the Washington, DC metropolitan area:

Number of restaurants

Restaurants/1,000 people

Yellow grease

Grease trap waste

Total grease resource
5,000

1.27

\begin{tabular}{|c|c|c|}
\hline Pounds/year & Pounds/year/person & Pounds/year/restaurant \\
\hline $39,000,000$ & 9.9 & 7,800 \\
\hline $50,000,000$ & 12.7 & 10,000 \\
\hline $89,000,000$ & 22.7 & 17,800 \\
\hline
\end{tabular}


The Richmond and Petersburg Yellow Pages list about 1,480 restaurants, two rendering companies, and 36 septic tank pumping companies. One rendering company, Valley Proteins Inc., did not return my phone calls. It is headquartered in Winchester, Virginia, and has rendering plants in the Baltimore area and somewhere in Virginia. The other rendering company, CBP Resources Inc. (Norfolk Tallow Co. Division), is located in Chesapeake, Virginia. It also has a Yellow Pages ad under the heading Grease Traps. The general manager said if I sent him a letter with my questions he would take a look at it, but that chances were good they would not respond with any quantitative information. These two companies undoubtedly process a large fraction of the restaurant grease from the Richmond-Petersburg area, but I was unable to obtain any estimates and had to resort to a factored estimate. Assuming a value of 10 pounds/year/person gives an estimate of about $8,700,000$ pounds/year.

The septic tank pumping companies that I talked to said that they discharge grease trap wastes into the sewage treatment system; exactly where and how they discharge depends on which county or city the waste comes from, but the material ends up in sewage treatment plants. Hanover County has a designated manhole where pump truckers pay $\$ 60$ per 1,000 gallons to discharge grease trap wastes. Hanover County does not have a wastewater treatment plant; its sewage is pumped into the Henrico County wastewater treatment plant (about 45 million gallons/day average inflow), which, oddly enough, does not allow grease trap wastes to be discharged at the facility. (Actually, the plant normally allows discharge, but has a moratorium. Several of the counties and the City of Richmond are grappling with the political issue of how best to handle grease trap wastes. The wastewater treatment plant managers all seem to feel that from a technical point of view it is best to have strong regulations requiring restaurants to have grease traps pumped regularly, and to have the waste discharged at the wastewater treatment plants where it can be properly treated and disposed of. However, local politics and lobbying by business owners often create much less effective approaches to the problem.)

The City of Richmond wastewater treatment plant (about 44 million gallons/day average inflow) recently started "officially" accepting grease trap wastes (meaning that they were "unofficially" accepted previously). The ballpark estimate of the plant manager was about 200,000 gallons/year of grease trap wastes discharged at the facility (out of a total of about $1,500,000$ gallons/year of total hauled waste (the rest being septage). Assuming a density of 7.3 pounds/gallon and a grease content of $10 \%$, I estimate that a total of about 150,000 pounds/year of grease are being discharged at the City of Richmond wastewater treatment plant by grease trap pump trucks. The treatment plant recently invested in an automated system to allow haulers to use magnetic cards, but the system has not been debugged yet. The City of Richmond monitors about 700 restaurants' discharges directly, enforcing a 300 ppm limit on grease, and assesses a $4.5 \%$ tax on restaurants' sales. The plant manager did not have direct data on the grease content in the raw sewage entering the plant, but suggested I use a figure of about $50 \mathrm{ppm}$.

Chesterfield County has two wastewater treatment plants (27 million gallons/day and 12 million gallons/day average inflow). The larger plant accepts grease trap waste. The total amount of grease trap wastes discharged at the plant during the last six months of 1997 was 67,700 gallons. Doubling this and assuming a density of 7.3 pounds/gallon and a grease content of $10 \%$, I estimate that a total of about 100,000 pounds/year of grease are being discharged at the Chesterfield County wastewater treatment plant by grease trap pump trucks. The plant manager has measured the oil and grease content in restaurants' effluents directly, but does not measure the oil and grease content in the raw sewage entering the treatment plants. 
In Petersburg, the South Central wastewater treatment plant has an average inflow of about 12 million gallons/day. It does not allow grease trap wastes to be discharged at the facility. The laboratory manager estimated that the oil and grease measurements in grab samples of the raw sewage average about $40 \mathrm{mg} /$ liter.

The table below summarizes the data I obtained on grease trap wastes in the RichmondPetersburg metropolitan area. To estimate the amount of grease flowing into these treatment plants with the raw sewage (remembering that the Henrico County plant receives grease trap pump truck wastes discharged at the Hanover County designated manhole), I assumed an average concentration of $40 \mathrm{ppm}$ grease in the 140 million gallons/day of raw sewage. This results in an estimate of about 17,000,000 pounds/year of grease trap waste entering the five treatment plants with the raw sewage. Combining this with the estimate of 250,000 pounds/year of grease discharged at two of the plants gives a total estimate for the Richmond-Petersburg metropolitan area of 17,300,000 pounds/year of grease entering wastewater treatment plants.

\begin{tabular}{|c|c|c|c|}
\hline $\begin{array}{c}\text { Wastewater treatment } \\
\text { plant }\end{array}$ & $\begin{array}{l}\text { Million gallons/day } \\
\text { average inflow }\end{array}$ & $\begin{array}{l}\text { Pounds/year grease } \\
\text { discharged by trucks }\end{array}$ & $\begin{array}{l}\text { Pounds/year grease } \\
\text { in raw sewage }\end{array}$ \\
\hline Henrico County & 45 & 0 & $5,500,000$ \\
\hline City of Richmond & 44 & 150,000 & $5,300,000$ \\
\hline Chesterfield Co. (2) & 39 & 100,000 & $4,700,000$ \\
\hline Petersburg & 12 & 0 & $1,500,000$ \\
\hline Total & 140 & 250,000 & $17,000,000$ \\
\hline
\end{tabular}

In summary, for the Richmond-Petersburg metropolitan area:

Number of restaurants

Restaurants/1,000 people

Yellow grease

Grease trap waste

Total grease resource
1,480

1.71

\begin{tabular}{|c|c|c|}
\hline Pounds/year & Pounds/year/person & Pounds/year/restaurant \\
\hline 000 & 10.1 & 5,900 \\
\hline $17,300,000$ & 20.0 & 11,700 \\
\hline $26,000,000$ & 30.0 & 17,600 \\
\hline
\end{tabular}

17. Danville, Virginia

Population (1990): 108,711

The Danville Yellow Pages list about 157 restaurants, no rendering companies, and five septic tank pumping companies. I assume the primary rendering company serving Danville restaurants is Valley Proteins Inc. I was unable to obtain any estimates and had to resort to a factored estimate. Assuming a value of 10 pounds/year/person for yellow grease in the Danville metropolitan area gives an estimate of about 1,100,000 pounds/year.

The septic tank pumping companies that I talked to said that they discharge grease trap wastes at the Danville wastewater treatment plant. The plant has an average raw sewage inflow of about 16 million gallons/day. The pretreatment manager said they do not measure the oil and grease concentrations in the raw sewage, and did not have records of the amount of grease trap waste discharged at the plant. Assuming an average concentration of $40 \mathrm{ppm}$ grease in the 16 million gallons/day of raw sewage results in an estimate of about 1,900,000 pounds/year of grease trap waste entering the treatment plant. 
In summary, for Danville:

Number of restaurants

Restaurants/1,000 people

157

1.44

\begin{tabular}{|c|c|c|}
\hline Pounds/year & Pounds/year/person & Pounds/year/restaurant \\
\hline 1,1 & 10.1 & 7,000 \\
\hline $1,900,000$ & 17.5 & 12,100 \\
\hline $3,000,000$ & 27.6 & 19,100 \\
\hline
\end{tabular}

Yellow grease

Grease trap waste

27.6

19,100

18. Fayetteville, North Carolina

Population (1990): 274,566

The Fayetteville Yellow Pages list about 384 restaurants, one rendering company, and 19 septic tank pumping companies. The rendering company serving most of the Fayetteville restaurants is Cape Fear Feed Products, a division of CBP Resources Inc. The environmental manager said that they cover a region from Myrtle Beach to about halfway to Charlotte, and that they work with the cities to remove wastes from restaurant grease traps (and thus from sewage treatment plants). He referred me to the general manager for estimates of quantities of grease recovered; the general manager did not return my calls. I had to resort to a factored estimate. Assuming a value of 10 pounds/year/person of yellow grease feedstock in the Fayetteville metropolitan area gives an estimate of about 2,700,000 pounds/year.

There are two sewage treatment plants in the Fayetteville metropolitan area. The Cross Creek plant has an average raw sewage inflow of about 13 million gallons/day, and the Rock Fish plant has an average raw sewage inflow of about 10 million gallons/day. Grease trap wastes are discharged at the plants, but the amounts are relatively small because Cape Fear Feed Products pumps the grease traps of the restaurants that have separate plumbing for grease traps. The pretreatment manager at the Cross Creek plant said they do not measure the oil and grease concentrations in the raw sewage, and she did not have records handy of the amount of grease trap waste discharged at the plant. Based on her comments, I assumed an average concentration of $30 \mathrm{ppm}$ grease in the 23 million gallons/day of raw sewage. This results in an estimate of about 2,100,000 pounds/year of grease trap waste entering the treatment plant.

In summary, for Fayetteville:

Number of restaurants

Restaurants/1,000 people

384

1.40

\begin{tabular}{|c|c|c|}
\hline Pounds/year & Pounds/year/person & Pounds/year/restaurant \\
\hline 00,00 & 9.8 & 7,000 \\
\hline $2,100,00$ & 7.6 & 5,500 \\
\hline $4,800,000$ & 17.5 & 12,500 \\
\hline
\end{tabular}

Yellow grease

Grease trap waste

Total grease resource

\section{Florence, South Carolina}

Population (1990): 114,344

The Florence Yellow Pages list about 185 restaurants, no rendering companies, and 11 septic tank pumping companies. I was unable to obtain estimates of the amounts of yellow grease feedstock recovered from Florence area restaurants, and used a factored estimate of 10 pounds/year/person, or about 1,100,000 pounds/year. The Florence sewage treatment plant has an average raw sewage inflow of about 8 million gallons/day. Grease trap wastes are discharged at the plant, but the amounts are relatively small. The pretreatment manager said they do not measure the oil and grease concentrations in the raw sewage, and he did 
not have records handy of the amount of grease trap waste discharged at the plant. Based on his comments, I assumed an average concentration of $35 \mathrm{ppm}$ grease in the 8 million gallons/day of raw sewage. This results in an estimate of about 900,000 pounds/year of grease trap waste entering the treatment plant.

In summary, for Florence:

Number of restaurants

185

Restaurants/1,000 people

1.62

Yellow grease

Grease trap waste

Total grease resource

\begin{tabular}{|c|c|c|}
\hline Pounds/year & Pounds/year/person & Pounds/year/restaurant \\
\hline $1,100,000$ & 9.6 & 5,900 \\
\hline 900,000 & 7.9 & 4,900 \\
\hline $2,000,000$ & 17.5 & 10,800 \\
\hline
\end{tabular}

\section{Greenville-Spartanburg, SC}

Population (1990): 640,861

The Greenville and Spartanburg Yellow Pages list about 1,017 restaurants, one rendering company, and 26 septic tank pumping companies. The rendering company serving most of the Greenville-Spartanburg restaurants is Valley Proteins Inc., of Ward, South Carolina. I spoke to the manager of that rendering plant, and he confirmed that they service most of the restaurants in the area. He referred me to the main office in Winchester, Virginia for estimates of quantities of grease recovered, who did not return my calls. I was unable to obtain any estimates and used a factored estimate of 10 pounds/year/person, or about $6,400,000$ pounds/year.

About $65 \%$ of the sewage in the Greenville area is treated at the Western Carolina wastewater treatment plant. The remaining $35 \%$ of the flow is treated by 20 or 30 much smaller plants around the area. The average flow rate of raw sewage into the Western Carolina plant is about 21 million gallons/day, so I estimate a total flow to all plants of about 32 million gallons/day. Grease trap pump trucks discharged a total of about 469,380 gallons/year of grease trap wastes at the Western Carolina plant in 1997. Assuming 7.3 pounds/gallon and 10\% grease content, this is about 340,000 pounds/year of grease. Based on the pretreatment coordinator's comments, I assumed an average concentration of $30 \mathrm{ppm}$ grease in the 32 million gallons/day of raw sewage to all plants. This results in an estimate of about 2,900,000 pounds/year of grease entering the treatment plants with the raw sewage. The total estimated grease trap waste for the Greenville area is 3,200,000 pounds/year.

The Spartanburg wastewater treatment plant has an average flow rate of about 10 million gallons/day. Grease trap pump trucks discharged a total of about 672,000 gallons/year of grease trap wastes at the Spartanburg plant in 1997. Assuming 7.3 pounds/gallon and 10\% grease content, this is about 490,000 pounds/year of grease. Based on the pretreatment coordinator's comments, I assumed an average concentration of $30 \mathrm{ppm}$ grease in the 10 million gallons/day of raw sewage to all plants. This results in an estimate of about 900,000 pounds/year of grease entering the treatment plant with the raw sewage. The total estimated grease trap waste for the Spartanburg area is about 1,400,000 pounds/year. The combined total of the estimates for grease trap waste in the Greenville-Spartanburg metropolitan area is about 4,600,000 pounds/year.

In summary, for Greenville-Spartanburg: 
Number of restaurants

Restaurants/1,000 people

Yellow grease

Grease trap waste

Total grease resource
1,017

1.59

\begin{tabular}{|c|c|c|}
\hline Pounds/year & Pounds/year/person & Pounds/year/restaurant \\
\hline $6,400,000$ & 10.0 & 6,300 \\
\hline $4,600,000$ & 7.2 & 4,500 \\
\hline $11,000,000$ & 17.2 & 10,800 \\
\hline
\end{tabular}

21. Lexington-Fayette, Kentucky

Population (1990): 348,428

The Lexington-Fayette Yellow Pages list about 562 restaurants, no rendering companies, and 10 septic tank pumping companies. The rendering company serving most of the Lexington-Fayette restaurants is Valley Proteins Inc. I was unable to obtain any estimates and used a factored estimate of 10 pounds/year/person, or about 3,500,000 pounds/year.

The sewage in the Lexington area is treated at the Main and South End wastewater treatment plants; the average flow rates of raw sewage into these plants are about 16 and 17 million gallons/day, respectively, so I estimate a total average flow to both plants of about 33 million gallons/day. Grease trap pump trucks discharged a total of about 156,000 gallons/year of grease trap wastes at the Main plant in 1997. Assuming 7.3 pounds/gallon and $10 \%$ grease content, this is about 110,000 pounds/year of grease. Based on the pretreatment coordinator's comments, I assumed an average concentration of $35 \mathrm{ppm}$ grease in the 33 million gallons/day of raw sewage to both plants. This results in an estimate of about 3,500,000 pounds/year of grease trap waste entering the treatment plants. The total estimated grease trap waste for the Lexington-Fayette area is about 3,600,000 pounds/year.

In summary, for Lexington-Fayette:

Number of restaurants

Restaurants/1,000 people

Yellow grease

Grease trap waste

Total grease resource

\section{2 \\ 1.61}

Pounds/year Pounds/year/person Pounds/year/restaurant

(3,

$3,600,000$

$7,100,000$

10.0

10.3

20.4

6,200

6,400

12,600

22. Memphis, Tennessee

Population (1990): 981,747

The Memphis Yellow Pages list about 1,128 restaurants, one rendering company, and nine septic tank pumping companies. The rendering company serving most of the Memphis restaurants is Griffin Industries Inc. I spoke to the manager of that rendering plant, and he confirmed that they service most of the restaurants in the area. He was unwilling to give me any data, however, so I used a factored estimate of 10 pounds/year/person, or about $9,800,000$ pounds/year.

The sewage in the Memphis area is treated at the North and TE Maxson (South) wastewater treatment plants; the average flow rates of raw sewage into these plants are about 75 and 90 million gallons/day, respectively, so I estimate a total average flow to both plants of about 165 million gallons/day. Pump trucks discharge grease trap wastes at the North plant; the pretreatment coordinator was unable to provide data on the total amount. In addition, the North plant receives effluent from a Protein Tech soybean processing plant and a Cargill corn processing plant. Based on the pretreatment coordinator's comments, I assumed an average concentration of $35 \mathrm{ppm}$ grease in the 165 million gallons/day of raw sewage to 
both plants. This results in an estimate of about 17,500,000 pounds/year of grease trap waste entering the treatment plants with the raw sewage. In addition, I estimate that pump trucks discharge another 1,000,000 pounds/year. The total estimated grease trap waste for the Memphis area, then, is about 18,500,000 pounds/year.

In summary, for Memphis:

Number of restaurants

1,128

Restaurants/1,000 people

1.15

Yellow grease

Grease trap waste

Total grease resource

\begin{tabular}{|c|c|c|}
\hline Pounds/year & Pounds/year/person & Pounds/year/restaurant \\
\hline 9 & 10.0 & 8,700 \\
\hline $18,500,000$ & 18.8 & 16,400 \\
\hline $28,300,000$ & 28.8 & 25,100 \\
\hline
\end{tabular}

23. Decatur, Alabama

Population (1990): 131,556

The Decatur Yellow Pages list about 245 restaurants, no rendering companies, and 10 septic tank pumping companies. I did not find out which rendering companies serve the Decatur area restaurants. Assuming a value of 10 pounds/year/person of yellow grease feedstock in the Decatur area gives an estimate of about 1,300,000 pounds/year.

The sewage in the Decatur area is treated at the Decatur Utilities wastewater treatment plant; the average flow rate of raw sewage into this plant is about 20 million gallons/day. Pump trucks are allowed to discharge grease trap wastes at the treatment plant, but the fee was recently raised to $\$ 100$ per 1,000 gallons of oil and grease, which is discouraging pump truck drivers from discharging grease trap wastes at the plant. About one truck per day has been discharging grease trap wastes at the plant, which I translated to an estimate of about 300,000 pounds/year of grease. Based on the chief operator's comments, I assumed an average concentration of $35 \mathrm{ppm}$ grease in the 20 million gallons/day of raw sewage to the plant. This resulted in an estimate of about 2,100,000 pounds/year of grease trap waste entering the treatment plant with the raw sewage. The total estimated grease trap waste for the Decatur area, then, is about 2,400,000 pounds/year.

In summary, for Decatur:

Number of restaurants

Restaurants/1,000 people

245

1.86

Yellow grease

Grease trap waste

Total grease resource

\begin{tabular}{|c|c|c|}
\hline Pounds/year & Pounds/year/person & Pounds/year/restaurant \\
\hline 1 , & 9.9 & 5,300 \\
\hline 00,000 & 18.2 & 9,800 \\
\hline $3,700,000$ & 28.1 & 15,100 \\
\hline
\end{tabular}

24. Macon-Warner Robins, Georgia

Population (1990): 281,103

The Macon and Warner Robins Yellow Pages list about 247 and 101 restaurants, respectively, giving an estimated total of 348 restaurants in the Macon-Warner Robins metropolitan area. The Yellow Pages list no rendering companies and six septic tank pumping companies. Two rendering companies serve the Macon-Warner Robins area restaurants: Mercer Grease Company and Griffin Industries. I talked to both companies and they confirmed that they collect restaurant grease in the area, but did not give me estimates of the quantities. Assuming a value of 10 pounds/year/person of yellow grease 
feedstock in the Macon-Warner Robins metropolitan area gives an estimate of about 2,800,000 pounds/year.

The sewage in the Macon area is treated at the Poplar Street and Rocky Creek wastewater treatment plants; the average flow rate of raw sewage into each of these plants is about 16 million gallons/day. Pump trucks are allowed to discharge grease trap wastes at the Poplar Street treatment plant. About 2.5 trucks per day discharge grease trap wastes at the plant, which I translated to an estimate of about 900,000 pounds/year of grease. Based on the plant manager's comments, I assumed an average concentration of $35 \mathrm{ppm}$ grease in the 32 million gallons/day of raw sewage to both plants. This resulted in an estimate of about $3,400,000$ pounds/year of grease trap waste entering the Macon treatment plants with the raw sewage.

The Warner Robins wastewater treatment plant does not allow discharge of grease trap wastes at the plant. The Roto-Rooter manager told me that if he were to pump grease traps in Warner Robins, he would have to take the material to Atlanta. The implication was that not many Warner Robins restaurants have their grease traps pumped. The average flow rate of raw sewage into the Warner Robins wastewater treatment plant is about 15 million gallons/day. Assuming an average concentration of $35 \mathrm{ppm}$ grease in the raw sewage to this plant, about 1,600,000 pounds/year of grease trap waste enter the Warner Robins treatment plant with the raw sewage. The total estimated grease trap waste for the MaconWarner Robins area, then, is about 5,900,000 pounds/year.

In summary, for Macon-Warner Robins:

Number of restaurants $\quad 348$

Restaurants/1,000 people $\quad 1.24$

\begin{tabular}{lccccc}
\cline { 2 - 2 } Yellow grease & Pounds/year & & Pounds/year/person & & Pounds/year/restaurant \\
Grease trap waste & $2,800,000$ & & 10.0 & & 8,000 \\
Total grease resource & $8,900,000$ & & 21.0 & & 17,000 \\
& $8,700,000$ & & 30.9 & & 25,000
\end{tabular}

\section{Lakeland-Winter Haven, Florida Population (1990): 405,382}

The Lakeland-Winter Haven Yellow Pages list about 445 restaurants, two rendering companies, and four grease trap pumping companies. Two rendering companies, Darling International and Griffin Industries, serve the Lakeland-Winter Haven area restaurants. I talked to both companies and they confirmed that they collect restaurant grease (both yellow grease feedstock and grease trap waste) in the area, but did not give me estimates of the quantities. Assuming a value of 10 pounds/year/person of yellow grease feedstock in the Lakeland-Winter Haven area gives an estimate of about 4,100,000 pounds/year.

The sewage in the Lakeland-Winter Haven metropolitan area is treated at the Glendale and Northside wastewater treatment plants in Lakeland; the Fairfax, \#2, and \#3 wastewater treatment plants in Winter Haven; the City of Bartow sewer plant; and the City of Auburndale sewer plant. The average flow rate of raw sewage into all of these plants taken together is about 40 million gallons/day. Pump trucks are not allowed to discharge grease trap wastes at any of these treatment plants. Based on the plant managers' comments, I assumed an average concentration of $35 \mathrm{ppm}$ grease in the 40 million gallons/day of raw sewage to all plants. This resulted in an estimate of about 4,200,000 pounds/year of grease trap waste entering the Lakeland-Winter Haven area treatment plants with the raw sewage. 
In addition to the two rendering companies, several other companies in the LakelandWinter Haven metropolitan area recover and process grease trap wastes. Nopec Corporation converts grease into biodiesel fuel, but was unwilling to give me any quantitative data on the amounts of grease they recover. Two septic tank service companies that I talked to bring grease trap waste to their own facilities and process it. I believe the processing consists of separation from water, $\mathrm{pH}$ adjustment of the grease with lime, and land spreading in accordance with permits from county and state environmental agencies. My guesstimate is that the amount of grease trap wastes recovered and processed is about $10 \%$ of the amount that enters the wastewater treatment plants with the raw sewage -- about 400,000 pounds/year. The total estimated grease trap waste for the Lakeland-Winter Haven area, then, is about $4,600,000$ pounds/year.

In summary, for Lakeland-Winter Haven:

Number of restaurants

Restaurants/1,000 people

Yellow grease

Grease trap waste

Total grease resource
445

1.10

\begin{tabular}{r} 
Pounds/year \\
\hline $4,100,000$ \\
$4,600,000$ \\
$8,700,000$
\end{tabular}

Pounds/year/person

10.1

11.3

21.5
Pounds/year/restaurant

9,200

10,300

19,600

26. Bradenton, Florida

Population (1990): 211,707

The Bradenton Yellow Pages list about 360 restaurants, one rendering company, and six grease trap pumping companies. Griffin Industries is the rendering company that serves the Bradenton area restaurants. They confirmed that they collect restaurant grease (both yellow grease feedstock and grease trap waste) in the area, but did not give me estimates of the quantities. Assuming a value of 10 pounds/year/person of yellow grease feedstock in the Bradenton metropolitan area gives an estimate of about 2,100,000 pounds/year.

The sewage in the Bradenton metropolitan area is treated at the Southeast and Southwest wastewater treatment plants in Bradenton, and three wastewater treatment plants in Manatee County. The average flow rate of raw sewage into all of these plants taken together is about 25 million gallons/day. Pump trucks are not allowed to discharge grease trap wastes at any of these treatment plants. Based on the plant managers' comments, I assumed an average concentration of $35 \mathrm{ppm}$ grease in the 25 million gallons/day of raw sewage to all plants. This resulted in an estimate of about 2,700,000 pounds/year of grease trap waste entering the Bradenton area treatment plants with the raw sewage.

In addition to the rendering company, several other companies in the Bradenton metropolitan area recover and process grease trap wastes. Two septic tank service companies that I talked to bring grease trap waste to their own facilities and process it. I believe the processing consists of separation from water, $\mathrm{pH}$ adjustment of the grease with lime, and land spreading in accordance with permits from county and state environmental agencies. My guesstimate is that the amount of grease trap wastes recovered and processed is about $10 \%$ of the amount that enters the wastewater treatment plants with the raw sewage -- about 300,000 pounds/year. The total estimated grease trap waste for the Bradenton area, then, is about 3,000,000 pounds/year.

In summary, for Bradenton: 
Number of restaurants

Restaurants/1,000 people

Yellow grease

Grease trap waste

Total grease resource
360

1.70

\begin{tabular}{|c|c|c|}
\hline Pounds/year & Pounds/year/person & Pounds/year/restaurant \\
\hline $2,100,000$ & 9.9 & 5,800 \\
\hline $3,000,000$ & 14.2 & 8,300 \\
\hline $5,100,000$ & 24.1 & 14,200 \\
\hline
\end{tabular}

27. Baton Rouge, Louisiana

Population (1990): 528,264

The Baton Rouge Yellow Pages list about 657 restaurants, three rendering companies, and seven grease trap pumping companies. The rendering companies are Darling International, Griffin Industries, and S Perkins Grease Service. All confirmed that they collect restaurant grease (both yellow grease feedstock and grease trap waste) in the area, but did not give me estimates of the quantities. Assuming a value of 10 pounds/year/person of yellow grease feedstock in the Baton Rouge area gives an estimate of about 5,300,000 pounds/year.

The sewage in the Baton Rouge metropolitan area is treated at the North, Central, and South wastewater treatment plants. The average flow rate of raw sewage into all of these plants taken together is about 50 million gallons/day. Pump trucks are not allowed to discharge grease trap wastes at any of these treatment plants. Based on the plant managers' comments, I assumed an average concentration of $35 \mathrm{ppm}$ grease in the 50 million gallons/day of raw sewage to all plants. This resulted in an estimate of about 5,300,000 pounds/year of grease trap waste entering the treatment plants with the raw sewage.

In addition to the rendering companies, several other companies in the Baton Rouge metropolitan area recover and process grease trap wastes by separation from water, $\mathrm{pH}$ adjustment, and land spreading. The City of Baton Rouge Environmental Division supervises the grease trap cleaning process as well as the processing and disposal. My guesstimate is that the amount of grease trap wastes recovered and processed is about $10 \%$ of the amount that enters the wastewater treatment plants with the raw sewage -- about 500,000 pounds/year. The total estimated grease trap waste for the Baton Rouge area is about 5,800,000 pounds/year.

In summary, for Baton Rouge:

Number of restaurants

Restaurants/1,000 people

Yellow grease

Grease trap waste

Total grease resource
657

1.24

\begin{tabular}{|c|c|c|}
\hline Pounds/year & Pounds/year/person & Pounds/year/restaurant \\
\hline 5 , & 10.0 & 8,100 \\
\hline $5,800,000$ & 11.0 & 8,800 \\
\hline $11,100,000$ & 21.0 & 16,900 \\
\hline
\end{tabular}

28. Shreveport, Louisiana

Population (1990): 334,341

The Shreveport Yellow Pages list about 442 restaurants, three rendering companies, and seven grease trap pumping companies. The rendering companies are Darling International, Griffin Industries, and Riegel By-Products Company. All confirmed that they collect restaurant grease (both yellow grease feedstock and grease trap waste) in the area, but did not give me estimates of the quantities. Assuming a value of 10 pounds/year/person of yellow grease feedstock gives an estimate of about 3,300,000 pounds/year. 
The sewage in the Shreveport metropolitan area is treated at the Lucas and North Regional wastewater treatment plants. The average flow rates of raw sewage into these plants are about 31 and 5 million gallons/day, respectively, for a total of about 36 million gallons/day. (These figures include significant amounts of infiltration into leaky sewer lines, according to the Lucas plant manager.) Pump trucks are not allowed to discharge grease trap wastes at either of these treatment plants. Based on the plant managers' comments, I assumed an average concentration of $25 \mathrm{ppm}$ grease in the 36 million gallons/day of raw sewage. This resulted in an estimate of about 2,700,000 pounds/year of grease trap waste entering the Shreveport area treatment plants with the raw sewage.

The city employee in charge of grease trap permitting said that when groceries, bakeries, fast food establishments, and restaurants are considered, the total number in the area is between 500 and 700. Three inspectors make the rounds, visiting every establishment once or twice a year. If the grease content in a restaurant's effluent exceeds $100 \mathrm{ppm}$ or if the $\mathrm{pH}$ is below 6 , the city orders that establishment to clean its grease trap.

In addition to the three rendering companies, two other companies (Bio-Vac Inc. and The Natural Solution Inc.) in the Shreveport metropolitan area recover and process grease trap wastes. The processing consists of separation from water, discharging the gray water to the sewer, neutralizing the $\mathrm{pH}$ of the grease with lime and/or treating the grease with bacteria, and taking the solids to the landfill. The Natural Solution Inc. uses a patented bioremediation process (bacteria) to convert the grease to inert solids. The owner of The Natural Solution Inc. estimated that the total amount of grease trap waste being collected and processed in the Shreveport metropolitan area is about 400,000 gallons/month. He said this material is about $90 \%$ water, $5 \%$ "trash", and 5\% grease. This converts to an estimated grease content of about 2,000,000 pounds/year. The total estimated grease trap waste for the Shreveport area, then, is about 4,700,000 pounds/year.

In summary, for Shreveport:

Number of restaurants

Restaurants/1,000 people

Yellow grease

Grease trap waste

Total grease resource
442

1.32

\begin{tabular}{|c|c|c|}
\hline Pounds/year & Pounds/year/person & Pounds/year/restaurant \\
\hline $3,300,000$ & 9.9 & 7,500 \\
\hline $4,700,000$ & 14.1 & 10,600 \\
\hline $8,000,000$ & 23.9 & 18,100 \\
\hline
\end{tabular}

29. Beaumont-Port Arthur, Texas

Population (1990): 361,226

The Beaumont and Port Arthur Yellow Pages list about 271 and 112 restaurants, no rendering companies, and four grease trap pumping companies. Darling International, based in Houston, is the primary rendering company serving the area restaurants. They confirmed that they collect restaurant grease (both yellow grease feedstock and grease trap waste) in the area, but did not give me estimates of the quantities. Assuming a value of 10 pounds/year/person of yellow grease feedstock in the Beaumont-Port Arthur metropolitan area gives an estimate of about 3,600,000 pounds/year.

The Beaumont wastewater treatment plant currently accepts grease trap discharges, but a plant is under construction by a private company (JTB Recycling Facility, Inc.) that will convert the grease trap wastes to products. When this plant is operating, the Beaumont wastewater treatment plant will stop accepting grease trap discharges. The wastewater treatment plant accepted a total of 867,720 gallons of grease trap truck discharges in 1997, or about 360,000 pounds/year of grease (assuming 5\% grease in the pump truck 
discharges). The average flow rate of raw sewage into the Beaumont wastewater treatment plant is about 22 million gallons/day.

Port Arthur has four wastewater treatment plants: the Main plant, which receives an average inflow of about 5-6 million gallons/day of raw sewage, and the much smaller Port Acres plant $(\sim 0.3$ million gallons/day), Sabine plant $(\sim 0.15)$, and Pleasure Island plant $(\sim 0.025)$. The cities of Groves, Nederland, and Port Neches all have their own wastewater treatment plants as well. None of these plants allow grease trap discharges; grease trap pumping companies in the Port Arthur area discharge their wastes at the Chemical Waste Management incinerator nearby, which was unable to give me an estimate of the total quantity of grease trap waste they receive. The incinerator receives hundreds of different types of wastes and chemicals, including PCBs and other hazardous wastes. I assumed the amount of grease trap wastes pumped in the Port Arthur area to be similar to Beaumont on a per-restaurant basis. This produced an estimate of about 140,000 pounds/year, giving a total of about 500,000 pounds/year for the metropolitan area as a whole.

The grand total raw sewage inflow to the seven Port Arthur area wastewater treatment plants is about 10 million gallons/day. Thus, the total average flow rate of raw sewage into the Beaumont-Port Arthur metropolitan area wastewater treatment plants is about 32 million gallons/day. Based on the plant managers' comments, I assumed an average concentration of $35 \mathrm{ppm}$ grease in the raw sewage to all plants. This resulted in an estimate of about $3,400,000$ pounds/year of grease trap waste entering the Beaumont-Port Arthur area treatment plants with the raw sewage. The total estimated grease trap waste for the Beaumont-Port Arthur area, then, is about 3,900,000 pounds/year.

In summary, for Beaumont-Port Arthur:

Number of restaurants

Restaurants/1,000 people

Yellow grease

Grease trap waste

Total grease resource

\begin{tabular}{|c|c|c|}
\hline $\begin{array}{c}383 \\
1.06 \\
\text { Pounds/year }\end{array}$ & Pounds/year/person & Pounds/year/restaurant \\
\hline $3,600,000$ & 10.0 & 9,400 \\
\hline $3,900,000$ & 10.8 & 10,200 \\
\hline $7,500,000$ & 20.8 & 19,600 \\
\hline
\end{tabular}

Population (1990): 121,862
The Bryan-College Station Yellow Pages list about 198 restaurants, no rendering companies, and four grease trap pumping companies. Darling International, based in Houston, is the primary rendering company serving the Bryan-College Station restaurants. They confirmed that they collect restaurant grease (both yellow grease feedstock and grease trap waste) in the area, but did not give me estimates of the quantities. Assuming a value of 10 pounds/year/person of yellow grease feedstock gives an estimate of about 1,200,000 pounds/year.

Bryan has three wastewater treatment plants that receive a total average inflow of about 9 million gallons/day. College Station has one wastewater treatment plant that receives an average of about 6 million gallons/day. Based on the plant managers' comments, I assumed an average concentration of $35 \mathrm{ppm}$ grease in the 15 million gallons/day of raw sewage to all plants. This resulted in an estimate of about 1,600,000 pounds/year of grease trap waste entering the Bryan-College Station area treatment plants with the raw sewage.

The grease trap pump trucks in Bryan-College Station discharge their material at Bryan wastewater treatment plant \#3, where a private company, Wastewater Systems, Inc., 
processes the material with bacteria. The gray water enters the treatment plant and the solids go to the landfill. Wastewater Systems, Inc.'s manager estimated that his facility treats an average of about 85,000 gallons/month of grease trap pump truck discharges, which I translated to about 420,000 pounds/year of grease (assuming $5 \%$ grease in the pump truck discharges). The total estimated grease trap waste for the Bryan-College Station area, then, is about 2,000,000 pounds/year.

In summary, for Bryan-College Station:

\begin{tabular}{lccccc} 
Number of restaurants & 198 & & & \\
Restaurants/1,000 people & $\begin{array}{c}1.62 \\
\text { Pounds/year }\end{array}$ & & Pounds/year/person & & Pounds/year/restaurant \\
\cline { 2 - 2 } Yellow grease & $1,200,000$ & & 9.8 & 6,100 \\
Grease trap waste & $2,000,000$ & & 16.4 & 10,100 \\
$\quad$ Total grease resource & $3,200,000$ & & 26.3 &
\end{tabular}




\section{APPENDIX A -- METROPOLITAN AREAS}

Table A1 lists the 281 metropolitan areas in the United States in order of population. Table A2 lists them by state. 
Table A1 - 281 Metropolitan Areas in Order of Population

\begin{tabular}{|c|c|c|c|c|c|}
\hline Metropolitan Area & State & $\begin{array}{c}1990 \\
\text { Ponulation }\end{array}$ & $\begin{array}{l}\text { Pop. } \\
\text { Rank }\end{array}$ & $\begin{array}{l}\text { Coal } \\
\text { MW }\end{array}$ & $\begin{array}{c}\text { Coal } \\
\text { Rank }\end{array}$ \\
\hline New York-Northern New Jersey-Long Island & NY & $17,953,372$ & 1 & 3,219 & 98 \\
\hline Los Angeles-Anaheim-Riverside & CA & $14,531,529$ & 2 & & 254 \\
\hline Chicago-Gary-Lake County & IL & $8,065,633$ & 3 & 11,253 & 16 \\
\hline San Francisco-Oakland-San Jose & $\mathrm{CA}$ & $6,253,311$ & 4 & & 272 \\
\hline Philadelphia-Wilmington-Trenton & PA & $5,899,345$ & 5 & 2,141 & 125 \\
\hline Detroit-Ann Arbor & MI & $4,665,236$ & 6 & 8,817 & 21 \\
\hline Washington & $\mathrm{DC}$ & $3,923,574$ & 7 & 5,810 & 45 \\
\hline Dallas-Ft. Worth & TX & $3,885,415$ & 8 & & 240 \\
\hline Boston-Lawrence-Salem-Lowell-Brockton & MA & $3,783,817$ & 9 & 2,164 & 123 \\
\hline Houston-Galveston-Brazoria & TX & $3,711,043$ & 10 & 2,697 & 109 \\
\hline Miami-Fort Lauderdale & FL & $3,192,582$ & 11 & & 258 \\
\hline Atlanta & GA & $2,833,511$ & 12 & 12,187 & 11 \\
\hline Cleveland-Akron-Lorain & $\mathrm{OH}$ & $2,759,823$ & 13 & 2,994 & 103 \\
\hline Seattle-Tacoma & WA & $2,559,164$ & 14 & 1,460 & 155 \\
\hline San Diego & CA & $2,498,016$ & 15 & & 271 \\
\hline Minneapolis-St. Paul & $\mathrm{MN}$ & $2,464,124$ & 16 & 4,586 & 65 \\
\hline St. Louis & $\mathrm{MO}$ & $2,444,099$ & 17 & 9,074 & 19 \\
\hline Baltimore & $\mathrm{MD}$ & $2,382,172$ & 18 & 5,700 & 48 \\
\hline Pittsburgh-Beaver Valley & PA & $2,242,798$ & 19 & 18,838 & 2 \\
\hline Phoenix & AZ & $2,122,101$ & 20 & 3,232 & 97 \\
\hline Tampa-St. Petersburg-Clearwater & FL & $2,067,959$ & 21 & 6,245 & 40 \\
\hline Denver-Boulder & $\mathrm{CO}$ & $1,848,319$ & 22 & 1,857 & 135 \\
\hline Cincinnati-Hamilton & $\mathrm{OH}$ & $1,744,124$ & 23 & 13,077 & 8 \\
\hline Milwaukee-Racine & WI & $1,607,183$ & 24 & 4,103 & 70 \\
\hline Kansas City & $\mathrm{MO}$ & $1,566,280$ & 25 & 5,405 & 54 \\
\hline Sacramento & $\mathrm{CA}$ & $1,481,102$ & 26 & & 267 \\
\hline Portland-Vancouver & OR & $1,477,895$ & 27 & & 264 \\
\hline Norfolk-Virginia Beach-Newport News & VA & $1,396,107$ & 28 & 3,260 & 94 \\
\hline Columbus & $\mathrm{OH}$ & $1,377,419$ & 29 & 2,728 & 107 \\
\hline San Antonio & TX & $1,302,099$ & 30 & 2,340 & 120 \\
\hline Indianapolis & IN & $1,249,822$ & 31 & 5,678 & 49 \\
\hline New Orleans & LA & $1,238,816$ & 32 & 750 & 193 \\
\hline Buffalo-Niagara Falls & NY & $1,189,288$ & 33 & 2,496 & 113 \\
\hline Charlotte-Gastonia-Rock Hill & $\mathrm{NC}$ & $1,162,093$ & 34 & 5,062 & 57 \\
\hline Hartford-New Britain-Middletown-Bristol & CT & $1,123,678$ & 35 & 1,302 & 163 \\
\hline Orlando & FL & $1,072,748$ & 36 & 1,606 & 145 \\
\hline Salt Lake City-Ogden & UT & $1,072,227$ & 37 & 69 & 227 \\
\hline Rochester & NY & $1,002,410$ & 38 & 2,251 & 121 \\
\hline Nashville & TN & 985,026 & 39 & 7,898 & 26 \\
\hline Memphis & TN & 981,747 & 40 & 990 & 184 \\
\hline Oklahoma City & $\mathrm{OK}$ & 958,839 & 41 & 1,138 & 176 \\
\hline Louisville & KY & 952,662 & 42 & 9,037 & 20 \\
\hline Dayton-Springfield & $\mathrm{OH}$ & 951,270 & 43 & 5,891 & 42 \\
\hline Greensboro-Winston-Salem-High Point & $\mathrm{NC}$ & 942,091 & 44 & 8,438 & 22 \\
\hline Providence-Pawtucket-Woonsocket & RI & 916,270 & 45 & 1,555 & 146 \\
\hline Birmingham & $\mathrm{AL}$ & 907,810 & 46 & 6,390 & 37 \\
\hline Jacksonville & FL & 906,727 & 47 & 2,913 & 104 \\
\hline
\end{tabular}


Table A1 - 281 Metropolitan Areas in Order of Population

\begin{tabular}{|c|c|c|c|c|c|}
\hline Metropolitan Area & State & $\begin{array}{c}1990 \\
\text { Population }\end{array}$ & $\begin{array}{l}\text { Pop. } \\
\text { Rank }\end{array}$ & $\begin{array}{l}\text { Coal } \\
\text { MW }\end{array}$ & $\begin{array}{l}\text { Coal } \\
\text { Rank }\end{array}$ \\
\hline Albany-Schenechtady-Troy & NY & 874,304 & 48 & 136 & 221 \\
\hline Richmond-Petersburg & VA & 865,640 & 49 & 4,116 & 68 \\
\hline West Palm Beach-Boca Raton-Delray Beach & FL & 863,518 & 50 & & 279 \\
\hline Honolulu & $\mathrm{HI}$ & 836,231 & 51 & & 249 \\
\hline New Haven-Waterbury-Meriden & CT & 804,219 & 52 & 1,166 & 173 \\
\hline Austin & TX & 781,572 & 53 & 3,621 & 82 \\
\hline Las Vegas & NV & 741,459 & 691 & 637 & 199 \\
\hline Raleigh-Durham & $\mathrm{NC}$ & 735,480 & 55 & 4,024 & 74 \\
\hline Scranton--Wilkes-Barre & PA & 734,175 & 56 & 2,515 & 112 \\
\hline Worcester-Fitchburg-Leominster & MA & 709,705 & 57 & 1,075 & 179 \\
\hline Tulsa & OK & 708,954 & 58 & 4,810 & 59 \\
\hline Grand Rapids & MI & 688,399 & 59 & 2,391 & 117 \\
\hline Allentown-Bethlehem & PA & 686,688 & 60 & 3,217 & 99 \\
\hline Fresno & $\mathrm{CA}$ & 667,490 & 61 & & 245 \\
\hline Tucson & AZ & 666,880 & 62 & 562 & 207 \\
\hline Syracuse & NY & 659,864 & 63 & 646 & 198 \\
\hline Greenville-Spartanburg & $\mathrm{SC}$ & 640,861 & 64 & 3,171 & 100 \\
\hline Omaha & $\mathrm{NE}$ & 618,262 & 65 & 2,476 & 115 \\
\hline Toledo & $\mathrm{OH}$ & 614,128 & 66 & 5,725 & 46 \\
\hline Knoxville & $\mathrm{TN}$ & 604,816 & 67 & 3,488 & 87 \\
\hline Springfield & MA & 602,878 & 68 & 136 & 224 \\
\hline El Paso & TX & 591,610 & 69 & & 241 \\
\hline Harrisburg-Lebanon-Carlisle & PA & 587,986 & 70 & 3,669 & 80 \\
\hline Bakersfield & $\mathrm{CA}$ & 543,477 & 71 & & 233 \\
\hline Baton Rouge & LA & 528,264 & 72 & 1,711 & 137 \\
\hline Little Rock-North Little Rock & AR & 513,117 & 73 & 1,700 & 139 \\
\hline Charleston & $\mathrm{SC}$ & 506,875 & 74 & 4,293 & 66 \\
\hline New Bedford-Fall River-Attleboro & MA & 506,325 & 75 & 1,225 & 170 \\
\hline Youngstown-Warren & $\mathrm{OH}$ & 492,619 & 76 & 10,491 & 17 \\
\hline Wichita & KS & 485,270 & 77 & & 280 \\
\hline Stockton & $\mathrm{CA}$ & 480,628 & 78 & & 277 \\
\hline Albuquerque & NM & 480,577 & 79 & & 231 \\
\hline Mobile & $\mathrm{AL}$ & 476,923 & 80 & 4,059 & 71 \\
\hline Columbia & $\mathrm{SC}$ & 453,331 & 81 & 3,577 & 85 \\
\hline Johnson City-Kingsport-Bristol & $\mathrm{TN}$ & 436,047 & 82 & 1,927 & 129 \\
\hline Chattanooga & TN & 433,210 & 83 & 8,121 & 24 \\
\hline Lansing-East Lansing & MI & 432,674 & 84 & 1,428 & 157 \\
\hline Flint & MI & 430,459 & 85 & 5,416 & 53 \\
\hline Lancaster & PA & 422,822 & 86 & 5,213 & 56 \\
\hline York & PA & 417,848 & 87 & 4,637 & 63 \\
\hline Lakeland-Winter Haven & FL & 405,382 & 88 & 4,731 & 61 \\
\hline Saginaw-Bay City-Midland & MI & 399,320 & 89 & 964 & 185 \\
\hline Melbourne-Titusville-Palm Bay & FL & 398,978 & 90 & 929 & 187 \\
\hline Colorado Springs & $\mathrm{CO}$ & 397,014 & 91 & 2,145 & 124 \\
\hline Augusta & GA & 396,809 & 92 & 2,707 & 108 \\
\hline Jackson & MS & 395,396 & 93 & & 250 \\
\hline Canton & $\mathrm{OH}$ & 394,106 & 94 & 4,729 & 62 \\
\hline
\end{tabular}


Table A1 - 281 Metropolitan Areas in Order of Population

\begin{tabular}{|c|c|c|c|c|c|}
\hline Metropolitan Area & & 1990 & Pop. & Coal & $\begin{array}{l}\text { Coal } \\
\text { Rank }\end{array}$ \\
\hline Des Moines & IA & 392928 & 95 & 1.019 & 182 \\
\hline McAllen-Edinburg-Mission & TX & 383,545 & 96 & & 255 \\
\hline Daytona Beach & FL & 370,712 & 97 & 1,304 & 162 \\
\hline Modesto & CA & 370,522 & 98 & & 260 \\
\hline Santa Barbara-Santa Maria-Lompoc & CA & 369,608 & 99 & & 273 \\
\hline Madison & WI & 367,085 & 100 & 1,692 & 141 \\
\hline Fort Wayne & IN & 363,811 & 101 & 149 & 220 \\
\hline Spokane & WA & 361,364 & 102 & & 276 \\
\hline Beaumont-Port Arthur & TX & 361,226 & 103 & 615 & 201 \\
\hline Salinas-Seaside-Monterey & $\mathrm{CA}$ & 355,660 & 104 & & 269 \\
\hline Davenport-Rock Island-Moline & IA & 350,861 & 105 & 2,754 & 106 \\
\hline Portsmouth-Dover-Rochester & $\mathrm{NH}$ & 350,078 & 106 & 609 & 203 \\
\hline Corpus Christi & TX & 349,894 & 107 & 600 & 204 \\
\hline Lexington-Fayette & KY & 348,428 & 108 & 13,245 & 7 \\
\hline Pensacola & FL & 344,406 & 109 & 2,906 & 105 \\
\hline Peoria & IL & 339,172 & 110 & 4,270 & 67 \\
\hline Reading & PA & 336,523 & 111 & 3,948 & 76 \\
\hline Manchester-Nashua & $\mathrm{NH}$ & 336,073 & 112 & 939 & 186 \\
\hline Fort Myers-Cape Coral & FL & 335,113 & 113 & & 243 \\
\hline Shreveport & LA & 334,341 & 114 & 5,496 & 51 \\
\hline Atlantic City & NJ & 319,416 & 115 & 1,759 & 136 \\
\hline Utica-Rome & NY & 316,633 & 116 & 75 & 226 \\
\hline Appleton-Oshkosh-Neenah & WI & 315,121 & 117 & 1,874 & 132 \\
\hline Huntington-Ashland & WV & 312,529 & 118 & 14,482 & 4 \\
\hline Visalia-Tulare-Porterville & $\mathrm{CA}$ & 311,921 & 119 & & 278 \\
\hline Montgomery & AL & 292,517 & 120 & 2,013 & 126 \\
\hline Rockford & IL & 283,719 & 121 & 5,831 & 44 \\
\hline Eugene-Springfield & OR & 282,912 & 122 & & 242 \\
\hline Macon-Warner Robins & GA & 281,103 & 123 & 5,491 & 52 \\
\hline Evansville & IN & 278,990 & 124 & 11,465 & 13 \\
\hline Salem & OR & 278,024 & 125 & & 268 \\
\hline Sarasota & FL & 277,776 & 126 & 3,125 & 101 \\
\hline Erie & PA & 275,572 & 127 & 1,236 & 168 \\
\hline Fayetteville & $\mathrm{NC}$ & 274,566 & 128 & 896 & 188 \\
\hline Binghamton & NY & 264,497 & 129 & 634 & 200 \\
\hline Provo-Orem & UT & 263,590 & 130 & 1,151 & 174 \\
\hline Brownsville-Harlingen & TX & 260,120 & 131 & & 237 \\
\hline Poughkeepsie & NY & 259,462 & 132 & 1,426 & 158 \\
\hline Killeen-Temple & TX & 255,301 & 133 & 793 & 192 \\
\hline New London-Norwich & CT & 254,957 & 134 & 1,625 & 143 \\
\hline Reno & NV & 254,667 & 135 & & 266 \\
\hline Fort Pierce & FL & 251,071 & 136 & & 244 \\
\hline Charleston & WV & 250,454 & 137 & 12,352 & 10 \\
\hline South Bend-Mishawaka & IN & 247,052 & 138 & 3,568 & 86 \\
\hline Portland & $\mathrm{ME}$ & 243,135 & 139 & 150 & 219 \\
\hline Columbus & GA & 243,072 & 140 & 3,392 & 89 \\
\hline Savannah & GA & 242,622 & 141 & 876 & 189 \\
\hline
\end{tabular}


Table A1 - 281 Metropolitan Areas in Order of Population

\begin{tabular}{|c|c|c|c|c|c|}
\hline Metropolitan Area & State & 1990 & Pop. & Coal & $\begin{array}{l}\text { Coal } \\
\text { Rank }\end{array}$ \\
\hline Johnstown & PA & 241,247 & 142 & 11,974 & 12 \\
\hline Springfield & MO & 240,593 & 143 & 679 & 195 \\
\hline Duluth & $\mathrm{MN}$ & 239,971 & 144 & 182 & 217 \\
\hline Huntsville & $\mathrm{AL}$ & 238,912 & 145 & 3,457 & 88 \\
\hline Tallahassee & FL & 233,598 & 146 & 98 & 225 \\
\hline Anchorage & $\mathrm{AK}$ & 226,338 & 147 & & 232 \\
\hline Roanoke & VA & 224,477 & 148 & 3,642 & 81 \\
\hline Kalamazoo & MI & 223,411 & 149 & 1,916 & 130 \\
\hline Lubbock & TX & 222,636 & 150 & 1,136 & 177 \\
\hline Hickory & $\mathrm{NC}$ & 221,700 & 151 & 3,987 & 75 \\
\hline Lincoln & $\mathrm{NE}$ & 213,641 & 152 & 2,476 & 114 \\
\hline Bradenton & FL & 211,707 & 153 & 3,802 & 79 \\
\hline Lafayette & LA & 208,740 & 154 & 1,711 & 138 \\
\hline Boise & ID & 205,775 & 155 & & 236 \\
\hline Gainesville & FL & 204,111 & 156 & 5,356 & 55 \\
\hline Biloxi-Gulfport & MS & 197,125 & 157 & 3,921 & 77 \\
\hline Ocala & FL & 194,833 & 158 & 4,927 & 58 \\
\hline Green Bay & WI & 194,594 & 159 & 1,243 & 167 \\
\hline St. Cloud & MN & 190,921 & 160 & 3,352 & 91 \\
\hline Bremerton & WA & 189,731 & 161 & 1,460 & 153 \\
\hline Springfield & IL & 189,550 & 162 & 8,258 & 23 \\
\hline Waco & TX & 189,123 & 163 & 3,607 & 83 \\
\hline Yakima & WA & 188,823 & 164 & 561 & 209 \\
\hline Amarillo & TX & 187,547 & 165 & 1,080 & 178 \\
\hline Fort Collins-Loveland & $\mathrm{CO}$ & 186,136 & 166 & 1,393 & 159 \\
\hline Houma-Thibodaux & LA & 182,842 & 167 & 25 & 229 \\
\hline Chico & CA & 182,120 & 168 & & 239 \\
\hline Merced & $\mathrm{CA}$ & 178,403 & 169 & & 257 \\
\hline Fort Smith & AR & 175,911 & 170 & 3,255 & 96 \\
\hline Asheville & $\mathrm{NC}$ & 174,821 & 171 & 2,350 & 119 \\
\hline Champaign-Urbana-Rantoul & IL & 173,025 & 172 & 5,865 & 43 \\
\hline Clarksville-Hopkinsville & $\mathrm{TN}$ & 169,439 & 173 & 11,257 & 15 \\
\hline Cedar Rapids & IA & 168,767 & 174 & 1,980 & 128 \\
\hline Lake Charles & LA & 168,134 & 175 & 615 & 202 \\
\hline Longview-Marshall & TX & 162,431 & 176 & 6,683 & 35 \\
\hline Benton Harbor & MI & 161,378 & 177 & 1,483 & 151 \\
\hline Olympia & WA & 161,238 & 178 & 1,460 & 154 \\
\hline Topeka & $\mathrm{KS}$ & 160,976 & 179 & 6,467 & 36 \\
\hline Wheeling & WV & 159,301 & 180 & 22,587 & 1 \\
\hline Muskegon & MI & 158,983 & 181 & 1,861 & 133 \\
\hline Athens & GA & 156,267 & 182 & 6,263 & 39 \\
\hline Elkhart-Goshen & IN & 156,198 & 183 & 1,547 & 148 \\
\hline Lima & $\mathrm{OH}$ & 154,340 & 184 & 703 & 194 \\
\hline Fargo-Moorhead & ND & 153,296 & 185 & 136 & 222 \\
\hline Naples & FL & 152,099 & 186 & & 262 \\
\hline Tyler & $\mathrm{TX}$ & 151,309 & 187 & 7,149 & 30 \\
\hline Tuscaloosa & AL & 150,522 & 188 & 6,820 & 34 \\
\hline
\end{tabular}


Table A1 - 281 Metropolitan Areas in Order of Population

\begin{tabular}{|c|c|c|c|c|c|}
\hline Metropolitan Area & State & $\begin{array}{c}1990 \\
\text { Population }\end{array}$ & $\begin{array}{l}\text { Pop. } \\
\text { Rank }\end{array}$ & $\begin{array}{l}\text { Coal } \\
\text { MW }\end{array}$ & $\begin{array}{c}\text { Coal } \\
\text { Rank }\end{array}$ \\
\hline Richland-Kennewick-Pasco & WA & 150.033 & 189 & 561 & 208 \\
\hline Jacksonville & $\mathrm{NC}$ & 149,838 & 190 & 1,074 & 180 \\
\hline Jackson & MI & 149,756 & 191 & 6,310 & 38 \\
\hline Parkersburg-Marietta & WV & 149,169 & 192 & 14,350 & 5 \\
\hline Redding & CA & 147,036 & 193 & & 265 \\
\hline Waterloo-Cedar Falls & IA & 146,611 & 194 & 804 & 191 \\
\hline Bangor & ME & 146,601 & 195 & & 234 \\
\hline Medford & OR & 146,389 & 196 & & 256 \\
\hline Anderson & $\mathrm{SC}$ & 145,196 & 197 & 1,550 & 147 \\
\hline Fort Walton Beach & FL & 143,776 & 198 & 1,475 & 152 \\
\hline Steubenville-Weirton & $\mathrm{OH}$ & 142,523 & 199 & 18,294 & 3 \\
\hline Lynchburg & VA & 142,199 & 200 & 254 & 214 \\
\hline Monroe & LA & 142,191 & 201 & & 261 \\
\hline Jamestown-Dunkirk & NY & 141,895 & 202 & 1,623 & 144 \\
\hline Janesville-Beloit & WI & 139,510 & 203 & 4,036 & 72 \\
\hline Pittsfield & MA & 139,352 & 204 & 136 & 223 \\
\hline Eau Claire & WI & 137,543 & 205 & 1,264 & 166 \\
\hline Burlington & VT & 137,079 & 206 & & 238 \\
\hline Battle Creek & MI & 135,982 & 207 & 585 & 206 \\
\hline Las Cruces & NM & 135,510 & 208 & & 252 \\
\hline Joplin & $\mathrm{MO}$ & 134,910 & 209 & 1,295 & 164 \\
\hline Laredo & TX & 133,239 & 210 & & 251 \\
\hline Greeley & $\mathrm{CO}$ & 131,821 & 211 & 1,893 & 131 \\
\hline Alexandria & LA & 131,556 & 212 & 2,244 & 122 \\
\hline Decatur & $\mathrm{AL}$ & 131,556 & 212 & 7,558 & 27 \\
\hline Florence & $\mathrm{AL}$ & 131,327 & 214 & 1,350 & 161 \\
\hline Charlottesville & VA & 131,107 & 215 & 1,455 & 156 \\
\hline Dothan & AL & 130,964 & 216 & 438 & 212 \\
\hline Terre Haute & IN & 130,812 & 217 & 9,528 & 18 \\
\hline Anderson & IN & 130,669 & 218 & 1,230 & 169 \\
\hline Lafayette-West Lafayette & IN & 130,598 & 219 & 5,707 & 47 \\
\hline Altoona & PA & 130,542 & 220 & 7,042 & 32 \\
\hline Bloomington-Normal & IL & 129,180 & 221 & 5,589 & 50 \\
\hline Bellingham & WA & 127,780 & 222 & & 235 \\
\hline Panama City & FL & 126,994 & 223 & 438 & 213 \\
\hline Mansfield & $\mathrm{OH}$ & 126,137 & 224 & 3,258 & 95 \\
\hline Sioux Falls & SD & 123,809 & 225 & 1,686 & 142 \\
\hline State College & PA & 123,786 & 226 & 4,607 & 64 \\
\hline Pueblo & $\mathrm{CO}$ & 123,051 & 227 & 1,203 & 172 \\
\hline Yuba City & CA & 122,643 & 228 & & 281 \\
\hline Wichita Falls & TX & 122,378 & 229 & 664 & 197 \\
\hline Bryan-College Station & TX & 121,862 & 230 & 4,110 & 69 \\
\hline Hagerstown & MD & 121,393 & 231 & 1,212 & 171 \\
\hline Sharon & PA & 121,003 & 232 & 2,364 & 118 \\
\hline Wilmington & $\mathrm{NC}$ & 120,284 & 233 & 1,001 & 183 \\
\hline Texarkana & TX & 120,132 & 234 & 3,582 & 84 \\
\hline Muncie & IN & 119,659 & 235 & 1,484 & 150 \\
\hline
\end{tabular}


Table A1 - 281 Metropolitan Areas in Order of Population

Table A1 - 281 Metropolitan Areas in Order of Population

\begin{tabular}{|c|c|c|c|c|c|}
\hline Metropolitan Area & State & $\begin{array}{c}1990 \\
\text { Population }\end{array}$ & $\begin{array}{l}\text { Pop. } \\
\text { Rank }\end{array}$ & $\begin{array}{l}\text { Coal } \\
\text { MW }\end{array}$ & $\begin{array}{l}\text { Coal } \\
\text { Rank }\end{array}$ \\
\hline Abilene & $\mathrm{TX}$ & 119,655 & 236 & & 230 \\
\hline Odessa & $\mathrm{TX}$ & 118,934 & 237 & & 263 \\
\hline Williamsport & PA & 118,710 & 238 & 2,566 & 111 \\
\hline Glens Falls & NY & 118,539 & 239 & & 246 \\
\hline Decatur & $\mathrm{IL}$ & 117,206 & 240 & 7,076 & 31 \\
\hline Santa Fe & NM & 117,043 & 241 & & 274 \\
\hline Anniston & $\mathrm{AL}$ & 116,034 & 242 & 12,817 & 9 \\
\hline Wausau & WI & 115,400 & 243 & 457 & 211 \\
\hline Pascagoula & MS & 115,243 & 244 & 3,921 & 78 \\
\hline Sioux City & IA & 115,018 & 245 & 1,860 & 134 \\
\hline Florence & $\mathrm{SC}$ & 114,344 & 246 & 3,289 & 93 \\
\hline Billings & MT & 113,419 & 247 & 191 & 216 \\
\hline Fayetteville-Springdale & $\mathrm{AR}$ & 113,409 & 248 & 3,343 & 92 \\
\hline Albany & GA & 112,561 & 249 & 231 & 215 \\
\hline Columbia & MO & 112,379 & 250 & 1,268 & 165 \\
\hline Lawton & OK & 111,486 & 251 & 664 & 196 \\
\hline Bloomington & IN & 108,978 & 252 & 7,256 & 29 \\
\hline Danville & VA & 108,711 & 253 & 4,760 & 60 \\
\hline Burlington & $\mathrm{NC}$ & 108,213 & 254 & 6,114 & 41 \\
\hline Midland & $\mathrm{TX}$ & 106,611 & 255 & & 259 \\
\hline Rochester & MN & 106,470 & 256 & 2,431 & 116 \\
\hline Lewiston-Auburn & ME & 105,259 & 257 & & 253 \\
\hline Sheboygan & WI & 103,877 & 258 & 3,027 & 102 \\
\hline Cumberland & $\mathrm{MD}$ & 101,643 & 259 & 7,414 & 28 \\
\hline Gadsden & $\mathrm{AL}$ & 99,840 & 260 & 11,285 & 14 \\
\hline San Angelo & $\mathrm{TX}$ & 98,458 & 261 & & 270 \\
\hline La Crosse & WI & 97,904 & 262 & 1,351 & 160 \\
\hline Kokomo & IN & 96,946 & 263 & 178 & 218 \\
\hline Kankakee & $\mathrm{IL}$ & 96,255 & 264 & 8,025 & 25 \\
\hline Iowa City & IA & 96,119 & 265 & 2,646 & 110 \\
\hline Elmira & NY & 95,195 & 266 & 559 & 210 \\
\hline Sherman-Denison & TX & 95,021 & 267 & & 275 \\
\hline Owensboro & KY & 87,189 & 268 & 14,307 & 6 \\
\hline Dubuque & IA & 86,403 & 269 & 1,042 & 181 \\
\hline Pine Bluff & $\mathrm{AR}$ & 85,487 & 270 & 1,700 & 140 \\
\hline Bismarck & ND & 83,831 & 271 & 4,034 & 73 \\
\hline St. Joseph & MO & 83,083 & 272 & 3,382 & 90 \\
\hline Lawrence & $\mathrm{KS}$ & 81,798 & 273 & 6,991 & 33 \\
\hline Rapid City & SD & 81,343 & 274 & 60 & 228 \\
\hline Jackson & $\mathrm{TN}$ & 77,982 & 275 & 1,485 & 149 \\
\hline Great Falls & MT & 77,691 & 276 & & 248 \\
\hline Victoria & TX & 74,361 & 277 & 600 & 205 \\
\hline Cheyenne & WY & 73,142 & 278 & 1,995 & 127 \\
\hline Grand Forks & ND & 70,683 & 279 & & 247 \\
\hline Casper & WY & 61,226 & 280 & 817 & 190 \\
\hline Enid & OK & 56,735 & 281 & 1,138 & 175 \\
\hline
\end{tabular}


Table A2 - 281 Metropolitan Areas by State

\begin{tabular}{|c|c|c|c|c|}
\hline Metropolitan Area & State & $\begin{array}{c}1990 \\
\text { Population }\end{array}$ & \begin{tabular}{|l|} 
Pop. \\
Rank
\end{tabular} & $\begin{array}{l}\text { State Metro } \\
\text { Population }\end{array}$ \\
\hline Anchorage & $\mathrm{AK}$ & 226,338 & 147 & 226,338 \\
\hline Birmingham & $\mathrm{AL}$ & 907,810 & 46 & \\
\hline Mobile & $\mathrm{AL}$ & 476,923 & 80 & \\
\hline Montgomery & $\mathrm{AL}$ & 292,517 & 120 & \\
\hline Huntsville & $\mathrm{AL}$ & 238,912 & 145 & \\
\hline Tuscaloosa & $\mathrm{AL}$ & 150,522 & 188 & \\
\hline Decatur & $\mathrm{AL}$ & 131,556 & 212 & \\
\hline Florence & $\mathrm{AL}$ & 131,327 & 214 & \\
\hline Dothan & $\mathrm{AL}$ & 130,964 & 216 & \\
\hline Anniston & $\mathrm{AL}$ & 116,034 & 242 & \\
\hline Gadsden & $\mathrm{AL}$ & 99,840 & 260 & $2,676,405$ \\
\hline Little Rock-North Little Rock & $\mathrm{AR}$ & 513,117 & 73 & \\
\hline Fort Smith & AR & 175,911 & 170 & \\
\hline Fayetteville-Springdale & AR & 113,409 & 248 & \\
\hline Pine Bluff & AR & 85,487 & 270 & 887,924 \\
\hline Phoenix & $\mathrm{AZ}$ & $2,122,101$ & 20 & \\
\hline Tucson & $\mathrm{AZ}$ & 666,880 & 62 & $2,788,981$ \\
\hline Los Angeles-Anaheim-Riverside & $\mathrm{CA}$ & $14,531,529$ & 2 & \\
\hline San Francisco-Oakland-San Jose & $\mathrm{CA}$ & $6,253,311$ & 4 & \\
\hline San Diego & $\mathrm{CA}$ & $2,498,016$ & 15 & \\
\hline Sacramento & CA & $1,481,102$ & 26 & \\
\hline Fresno & $\mathrm{CA}$ & 667,490 & 61 & \\
\hline Bakersfield & $\mathrm{CA}$ & 543,477 & 71 & \\
\hline Stockton & $\mathrm{CA}$ & 480,628 & 78 & \\
\hline Modesto & $\mathrm{CA}$ & 370,522 & 98 & \\
\hline Santa Barbara-Santa Maria-Lompoc & $\mathrm{CA}$ & 369,608 & 99 & \\
\hline Salinas-Seaside-Monterey & $\mathrm{CA}$ & 355,660 & 104 & \\
\hline Visalia-Tulare-Porterville & $\mathrm{CA}$ & 311,921 & 119 & \\
\hline Chico & $\mathrm{CA}$ & 182,120 & 168 & \\
\hline Merced & $\mathrm{CA}$ & 178,403 & 169 & \\
\hline Redding & $\mathrm{CA}$ & 147,036 & 193 & \\
\hline Yuba City & $\mathrm{CA}$ & 122,643 & 228 & $28,493,466$ \\
\hline Denver-Boulder & $\mathrm{CO}$ & $1,848,319$ & 22 & \\
\hline Colorado Springs & $\mathrm{CO}$ & 397,014 & 91 & \\
\hline Fort Collins-Loveland & $\mathrm{CO}$ & 186,136 & 166 & \\
\hline Greeley & $\mathrm{CO}$ & 131,821 & 211 & \\
\hline Pueblo & $\mathrm{CO}$ & 123,051 & 227 & $2,686,341$ \\
\hline Hartford-New Britain-Middletown-Bristol & CT & $1,123,678$ & 35 & \\
\hline New Haven-Waterbury-Meriden & CT & 804,219 & 52 & \\
\hline New London-Norwich & CT & 254,957 & 134 & $2,182,854$ \\
\hline Washington & $\mathrm{DC}$ & $3,923,574$ & 7 & $3,923,574$ \\
\hline Miami-Fort Lauderdale & FL & $3,192,582$ & 11 & \\
\hline Tampa-St. Petersburg-Clearwater & FL & $2,067,959$ & 21 & \\
\hline Orlando & FL & $1,072,748$ & 36 & \\
\hline Jacksonville & FL & 906,727 & 47 & \\
\hline West Palm Beach-Boca Raton-Delray Beach & FL & 863,518 & 50 & \\
\hline Lakeland-Winter Haven & FL & 405,382 & 88 & \\
\hline Melbourne-Titusville-Palm Bay & FL & 398,978 & 90 & \\
\hline
\end{tabular}


Table A2 - 281 Metropolitan Areas by State

\begin{tabular}{|c|c|c|c|c|}
\hline Metropolitan Area & State & $\begin{array}{c}1990 \\
\text { Population }\end{array}$ & $\begin{array}{l}\text { Pop. } \\
\text { Rank }\end{array}$ & $\begin{array}{l}\text { State Metro } \\
\text { Population }\end{array}$ \\
\hline Daytona Beach & FL & 370,712 & 97 & \\
\hline Pensacola & FL & 344,406 & 109 & \\
\hline Fort Myers-Cape Coral & FL & 335,113 & 113 & \\
\hline Sarasota & FL & 277,776 & 126 & \\
\hline Fort Pierce & FL & 251,071 & 136 & \\
\hline Tallahassee & FL & 233,598 & 146 & \\
\hline Bradenton & FL & 211,707 & 153 & \\
\hline Gainesville & FL & 204,111 & 156 & \\
\hline Ocala & FL & 194,833 & 158 & \\
\hline Naples & FL & 152,099 & 186 & \\
\hline Fort Walton Beach & FL & 143,776 & 198 & \\
\hline Panama City & FL & 126,994 & 223 & $11,754,090$ \\
\hline Atlanta & GA & $2,833,511$ & 12 & \\
\hline Augusta & GA & 396,809 & 92 & \\
\hline Macon-Warner Robins & $\mathrm{GA}$ & 281,103 & 123 & \\
\hline Columbus & GA & 243,072 & 140 & \\
\hline Savannah & GA & 242,622 & 141 & \\
\hline Athens & GA & 156,267 & 182 & \\
\hline Albany & GA & 112,561 & 249 & $4,265,945$ \\
\hline Honolulu & $\mathrm{HI}$ & 836,231 & 51 & 836,231 \\
\hline Des Moines & IA & 392,928 & 95 & \\
\hline Davenport-Rock Island-Moline & IA & 350,861 & 105 & \\
\hline Cedar Rapids & IA & 168,767 & 174 & \\
\hline Waterloo-Cedar Falls & IA & 146,611 & 194 & \\
\hline Sioux City & IA & 115,018 & 245 & \\
\hline Iowa City & IA & 96,119 & 265 & \\
\hline Dubuque & IA & 86,403 & 269 & $1,356,707$ \\
\hline Boise & $\mathrm{ID}$ & 205,775 & 155 & 205,775 \\
\hline Chicago-Gary-Lake County & $\mathrm{IL}$ & $8,065,633$ & 3 & \\
\hline Peoria & $\mathrm{IL}$ & 339,172 & 110 & \\
\hline Rockford & $\mathrm{IL}$ & 283,719 & 121 & \\
\hline Springfield & $\mathrm{IL}$ & 189,550 & 162 & \\
\hline Champaign-Urbana-Rantoul & $\mathrm{IL}$ & 173,025 & 172 & \\
\hline Bloomington-Normal & $\mathrm{IL}$ & 129,180 & 221 & \\
\hline Decatur & $\mathrm{IL}$ & 117,206 & 240 & \\
\hline Kankakee & $\mathrm{IL}$ & 96,255 & 264 & $9,393,740$ \\
\hline Indianapolis & IN & $1,249,822$ & 31 & \\
\hline Fort Wayne & IN & 363,811 & 101 & \\
\hline Evansville & IN & 278,990 & 124 & \\
\hline South Bend-Mishawaka & IN & 247,052 & 138 & \\
\hline Elkhart-Goshen & IN & 156,198 & 183 & \\
\hline Terre Haute & IN & 130,812 & 217 & \\
\hline Anderson & IN & 130,669 & 218 & \\
\hline Lafayette-West Lafayette & IN & 130,598 & 219 & \\
\hline Muncie & IN & 119,659 & 235 & \\
\hline Bloomington & IN & 108,978 & 252 & \\
\hline Kokomo & IN & 96,946 & 263 & $3,013,535$ \\
\hline Wichita & KS & 485,270 & 77 & \\
\hline
\end{tabular}


Table A2 - 281 Metropolitan Areas by State

\begin{tabular}{|c|c|c|c|c|}
\hline Metropolitan Area & State & $\begin{array}{c}1990 \\
\text { Population }\end{array}$ & $\begin{array}{l}\text { Pop. } \\
\text { Rank }\end{array}$ & $\begin{array}{l}\text { State Metro } \\
\text { Population }\end{array}$ \\
\hline Topeka & $\mathrm{KS}$ & 160,976 & 179 & \\
\hline Lawrence & $\mathrm{KS}$ & 81,798 & 273 & 728,044 \\
\hline Louisville & KY & 952,662 & 42 & \\
\hline Lexington-Fayette & KY & 348,428 & 108 & \\
\hline Owensboro & KY & 87,189 & 268 & $1,388,279$ \\
\hline New Orleans & LA & $1,238,816$ & 32 & \\
\hline Baton Rouge & LA & 528,264 & 72 & \\
\hline Shreveport & LA & 334,341 & 114 & \\
\hline Lafayette & LA & 208,740 & 154 & \\
\hline Houma-Thibodaux & LA & 182,842 & 167 & \\
\hline Lake Charles & LA & 168,134 & 175 & \\
\hline Monroe & LA & 142,191 & 201 & \\
\hline Alexandria & LA & 131,556 & 212 & $2,934,884$ \\
\hline Boston-Lawrence-Salem-Lowell-Brockton & MA & $3,783,817$ & 9 & \\
\hline Worcester-Fitchburg-Leominster & MA & 709,705 & 57 & \\
\hline Springfield & MA & 602,878 & 68 & \\
\hline New Bedford-Fall River-Attleboro & MA & 506,325 & 75 & \\
\hline Pittsfield & MA & 139,352 & 204 & $5,742,077$ \\
\hline Baltimore & MD & $2,382,172$ & 18 & \\
\hline Hagerstown & MD & 121,393 & 231 & \\
\hline Cumberland & MD & 101,643 & 259 & $2,605,208$ \\
\hline Portland & $\mathrm{ME}$ & 243,135 & 139 & \\
\hline Bangor & ME & 146,601 & 195 & \\
\hline Lewiston-Auburn & $\mathrm{ME}$ & 105,259 & 257 & 494,995 \\
\hline Detroit-Ann Arbor & MI & $4,665,236$ & 6 & \\
\hline Grand Rapids & MI & 688,399 & 59 & \\
\hline Lansing-East Lansing & MI & 432,674 & 84 & \\
\hline Flint & MI & 430,459 & 85 & \\
\hline Saginaw-Bay City-Midland & MI & 399,320 & 89 & \\
\hline Kalamazoo & MI & 223,411 & 149 & \\
\hline Benton Harbor & MI & 161,378 & 177 & \\
\hline Muskegon & MI & 158,983 & 181 & \\
\hline Jackson & MI & 149,756 & 191 & \\
\hline Battle Creek & MI & 135,982 & 207 & $7,445,598$ \\
\hline Minneapolis-St. Paul & $\mathrm{MN}$ & $2,464,124$ & 16 & \\
\hline Duluth & $\mathrm{MN}$ & 239,971 & 144 & \\
\hline St. Cloud & $\mathrm{MN}$ & 190,921 & 160 & \\
\hline Rochester & $\mathrm{MN}$ & 106,470 & 256 & $3,001,486$ \\
\hline St. Louis & $\mathrm{MO}$ & $2,444,099$ & 17 & \\
\hline Kansas City & $\mathrm{MO}$ & $1,566,280$ & 25 & \\
\hline Springfield & $\mathrm{MO}$ & 240,593 & 143 & \\
\hline Joplin & $\mathrm{MO}$ & 134,910 & 209 & \\
\hline Columbia & $\mathrm{MO}$ & 112,379 & 250 & \\
\hline St. Joseph & $\mathrm{MO}$ & 83,083 & 272 & $4,581,344$ \\
\hline Jackson & MS & 395,396 & 93 & \\
\hline Biloxi-Gulfport & MS & 197,125 & 157 & \\
\hline Pascagoula & MS & 115,243 & 244 & 707,764 \\
\hline Billings & MT & 113,419 & 247 & \\
\hline
\end{tabular}


Table A2 - 281 Metropolitan Areas by State

\begin{tabular}{|c|c|c|c|c|}
\hline Metropolitan Area & State & $\begin{array}{c}1990 \\
\text { Population }\end{array}$ & $\begin{array}{l}\text { Pop. } \\
\text { Rank }\end{array}$ & $\begin{array}{l}\text { State Metro } \\
\text { Population }\end{array}$ \\
\hline Great Falls & $\mathrm{MT}$ & 77,691 & 276 & 191,110 \\
\hline Charlotte-Gastonia-Rock Hill & $\mathrm{NC}$ & $1,162,093$ & 34 & \\
\hline Greensboro-Winston-Salem-High Point & $\mathrm{NC}$ & 942,091 & 44 & \\
\hline Raleigh-Durham & $\mathrm{NC}$ & 735,480 & 55 & \\
\hline Fayetteville & $\mathrm{NC}$ & 274,566 & 128 & \\
\hline Hickory & $\mathrm{NC}$ & 221,700 & 151 & \\
\hline Asheville & $\mathrm{NC}$ & 174,821 & 171 & \\
\hline Jacksonville & $\mathrm{NC}$ & 149,838 & 190 & \\
\hline Wilmington & $\mathrm{NC}$ & 120,284 & 233 & \\
\hline Burlington & $\mathrm{NC}$ & 108,213 & 254 & $3,889,086$ \\
\hline Fargo-Moorhead & ND & 153,296 & 185 & \\
\hline Bismarck & ND & 83,831 & 271 & \\
\hline Grand Forks & ND & 70,683 & 279 & 307,810 \\
\hline Omaha & $\mathrm{NE}$ & 618,262 & 65 & \\
\hline Lincoln & $\mathrm{NE}$ & 213,641 & 152 & 831,903 \\
\hline Portsmouth-Dover-Rochester & $\mathrm{NH}$ & 350,078 & 106 & \\
\hline Manchester-Nashua & $\mathrm{NH}$ & 336,073 & 112 & 686,151 \\
\hline Atlantic City & $\mathrm{NJ}$ & 319,416 & 115 & 319,416 \\
\hline Albuquerque & NM & 480,577 & 79 & \\
\hline Las Cruces & NM & 135,510 & 208 & \\
\hline Santa Fe & NM & 117,043 & 241 & 733,130 \\
\hline Las Vegas & NV & 741,459 & 691 & \\
\hline Reno & $\mathrm{NV}$ & 254,667 & 135 & 996,126 \\
\hline New York-Northern New Jersey-Long Island & NY & $17,953,372$ & 1 & \\
\hline Buffalo-Niagara Falls & NY & $1,189,288$ & 33 & \\
\hline Rochester & NY & $1,002,410$ & 38 & \\
\hline Albany-Schenechtady-Troy & NY & 874,304 & 48 & \\
\hline Syracuse & NY & 659,864 & 63 & \\
\hline Utica-Rome & NY & 316,633 & 116 & \\
\hline Binghamton & NY & 264,497 & 129 & \\
\hline Poughkeepsie & NY & 259,462 & 132 & \\
\hline Jamestown-Dunkirk & NY & 141,895 & 202 & \\
\hline Glens Falls & NY & 118,539 & 239 & \\
\hline Elmira & NY & 95,195 & 266 & $22,875,459$ \\
\hline Cleveland-Akron-Lorain & $\mathrm{OH}$ & $2,759,823$ & 13 & \\
\hline Cincinnati-Hamilton & $\mathrm{OH}$ & $1,744,124$ & 23 & \\
\hline Columbus & $\mathrm{OH}$ & $1,377,419$ & 29 & \\
\hline Dayton-Springfield & $\mathrm{OH}$ & 951,270 & 43 & \\
\hline Toledo & $\mathrm{OH}$ & 614,128 & 66 & \\
\hline Youngstown-Warren & $\mathrm{OH}$ & 492,619 & 76 & \\
\hline Canton & $\mathrm{OH}$ & 394,106 & 94 & \\
\hline Lima & $\mathrm{OH}$ & 154,340 & 184 & \\
\hline Steubenville-Weirton & $\mathrm{OH}$ & 142,523 & 199 & \\
\hline Mansfield & $\mathrm{OH}$ & 126,137 & 224 & $8,756,489$ \\
\hline Oklahoma City & $\mathrm{OK}$ & 958,839 & 41 & \\
\hline Tulsa & $\mathrm{OK}$ & 708,954 & 58 & \\
\hline Lawton & $\mathrm{OK}$ & 111,486 & 251 & \\
\hline Enid & $\mathrm{OK}$ & 56,735 & 281 & $1,836,014$ \\
\hline
\end{tabular}


Table A2 - 281 Metropolitan Areas by State

\begin{tabular}{|c|c|c|c|c|}
\hline Metropolitan Area & State & $\begin{array}{c}1990 \\
\text { Population }\end{array}$ & $\begin{array}{l}\text { Pop. } \\
\text { Rank }\end{array}$ & $\begin{array}{l}\text { State Metro } \\
\text { Population }\end{array}$ \\
\hline Portland-Vancouver & OR & $1,477,895$ & 27 & \\
\hline Eugene-Springfield & OR & 282,912 & 122 & \\
\hline Salem & OR & 278,024 & 125 & \\
\hline Medford & OR & 146,389 & 196 & $2,185,220$ \\
\hline Philadelphia-Wilmington-Trenton & PA & $5,899,345$ & 5 & \\
\hline Pittsburgh-Beaver Valley & PA & $2,242,798$ & 19 & \\
\hline Scranton--Wilkes-Barre & PA & 734,175 & 56 & \\
\hline Allentown-Bethlehem & $\mathrm{PA}$ & 686,688 & 60 & \\
\hline Harrisburg-Lebanon-Carlisle & PA & 587,986 & 70 & \\
\hline Lancaster & PA & 422,822 & 86 & \\
\hline York & $\mathrm{PA}$ & 417,848 & 87 & \\
\hline Reading & PA & 336,523 & 111 & \\
\hline Erie & PA & 275,572 & 127 & \\
\hline Johnstown & PA & 241,247 & 142 & \\
\hline Altoona & $\mathrm{PA}$ & 130,542 & 220 & \\
\hline State College & PA & 123,786 & 226 & \\
\hline Sharon & PA & 121,003 & 232 & \\
\hline Williamsport & $\mathrm{PA}$ & 118,710 & 238 & $12,339,045$ \\
\hline Providence-Pawtucket-Woonsocket & RI & 916,270 & 45 & 916,270 \\
\hline Greenville-Spartanburg & $\mathrm{SC}$ & 640,861 & 64 & \\
\hline Charleston & $\mathrm{SC}$ & 506,875 & 74 & \\
\hline Columbia & $\mathrm{SC}$ & 453,331 & 81 & \\
\hline Anderson & $\mathrm{SC}$ & 145,196 & 197 & \\
\hline Florence & $\mathrm{SC}$ & 114,344 & 246 & $1,860,607$ \\
\hline Sioux Falls & SD & 123,809 & 225 & \\
\hline Rapid City & SD & 81,343 & 274 & 205,152 \\
\hline Nashville & $\mathrm{TN}$ & 985,026 & 39 & \\
\hline Memphis & TN & 981,747 & 40 & \\
\hline Knoxville & TN & 604,816 & 67 & \\
\hline Johnson City-Kingsport-Bristol & TN & 436,047 & 82 & \\
\hline Chattanooga & $\mathrm{TN}$ & 433,210 & 83 & \\
\hline Clarksville-Hopkinsville & TN & 169,439 & 173 & \\
\hline Jackson & TN & 77,982 & 275 & $3,688,267$ \\
\hline Dallas-Ft. Worth & TX & $3,885,415$ & 8 & \\
\hline Houston-Galveston-Brazoria & TX & $3,711,043$ & 10 & \\
\hline San Antonio & TX & $1,302,099$ & 30 & \\
\hline Austin & TX & 781,572 & 53 & \\
\hline El Paso & TX & 591,610 & 69 & \\
\hline McAllen-Edinburg-Mission & TX & 383,545 & 96 & \\
\hline Beaumont-Port Arthur & TX & 361,226 & 103 & \\
\hline Corpus Christi & TX & 349,894 & 107 & \\
\hline Brownsville-Harlingen & TX & 260,120 & 131 & \\
\hline Killeen-Temple & TX & 255,301 & 133 & \\
\hline Lubbock & TX & 222,636 & 150 & \\
\hline Waco & TX & 189,123 & 163 & \\
\hline Amarillo & TX & 187,547 & 165 & \\
\hline Longview-Marshall & TX & 162,431 & 176 & \\
\hline Tyler & TX & 151,309 & 187 & \\
\hline
\end{tabular}


Table A2 - 281 Metropolitan Areas by State

\begin{tabular}{|c|c|c|c|c|}
\hline Metropolitan Area & State & $\begin{array}{c}1990 \\
\text { Population }\end{array}$ & $\begin{array}{l}\text { Pop. } \\
\text { Rank }\end{array}$ & $\begin{array}{l}\text { State Metro } \\
\text { Population }\end{array}$ \\
\hline Laredo & TX & 133,239 & 210 & \\
\hline Wichita Falls & TX & 122,378 & 229 & \\
\hline Bryan-College Station & TX & 121,862 & 230 & \\
\hline Texarkana & TX & 120,132 & 234 & \\
\hline Abilene & TX & 119,655 & 236 & \\
\hline Odessa & TX & 118,934 & 237 & \\
\hline Midland & TX & 106,611 & 255 & \\
\hline San Angelo & TX & 98,458 & 261 & \\
\hline Sherman-Denison & TX & 95,021 & 267 & \\
\hline Victoria & TX & 74,361 & 277 & $13,905,522$ \\
\hline Salt Lake City-Ogden & UT & $1,072,227$ & 37 & \\
\hline Provo-Orem & UT & 263,590 & 130 & $1,335,817$ \\
\hline Norfolk-Virginia Beach-Newport News & VA & $1,396,107$ & 28 & \\
\hline Richmond-Petersburg & VA & 865,640 & 49 & \\
\hline Roanoke & VA & 224,477 & 148 & \\
\hline Lynchburg & VA & 142,199 & 200 & \\
\hline Charlottesville & VA & 131,107 & 215 & \\
\hline Danville & VA & 108,711 & 253 & $2,868,241$ \\
\hline Burlington & VT & 137,079 & 206 & 137,079 \\
\hline Seattle-Tacoma & WA & $2,559,164$ & 14 & \\
\hline Spokane & WA & 361,364 & 102 & \\
\hline Bremerton & WA & 189,731 & 161 & \\
\hline Yakima & WA & 188,823 & 164 & \\
\hline Olympia & WA & 161,238 & 178 & \\
\hline Richland-Kennewick-Pasco & WA & 150,033 & 189 & \\
\hline Bellingham & WA & 127,780 & 222 & $3,738,133$ \\
\hline Milwaukee-Racine & WI & $1,607,183$ & 24 & \\
\hline Madison & WI & 367,085 & 100 & \\
\hline Appleton-Oshkosh-Neenah & WI & 315,121 & 117 & \\
\hline Green Bay & WI & 194,594 & 159 & \\
\hline Janesville-Beloit & WI & 139,510 & 203 & \\
\hline Eau Claire & WI & 137,543 & 205 & \\
\hline Wausau & WI & 115,400 & 243 & \\
\hline Sheboygan & WI & 103,877 & 258 & \\
\hline La Crosse & WI & 97,904 & 262 & $3,078,217$ \\
\hline Huntington-Ashland & WV & 312,529 & 118 & \\
\hline Charleston & WV & 250,454 & 137 & \\
\hline Wheeling & WV & 159,301 & 180 & \\
\hline Parkersburg-Marietta & WV & 149,169 & 192 & 871,453 \\
\hline Cheyenne & WY & 73,142 & 278 & \\
\hline Casper & WY & 61,226 & 280 & 134,368 \\
\hline
\end{tabular}




\section{APPENDIX B -- SURVEY FORMS AND QUESTIONS}

Survey forms and questions are included in this Appendix for the following categories of respondents:

1. Sewage treatment plants

2. Grease collection/rendering companies

3. Restaurants 


\section{Sewage Treatment Plants}

Hello (introduction). I'm doing a study of urban waste grease resources for the National Renewable Energy Laboratory. Do you have a few minutes to answer some quick questions?

Company name:

Address:

Contact:

Phone number:

1. What is the average flow rate of raw sewage into your treatment plant?

2. Do you measure the concentration of oil and grease in the raw sewage?

a. If so, what are the concentrations?

b. If not, what do you think the concentrations are?

3. Do you allow grease trap pump trucks to discharge at your facility?

a. If so, how many gallons (or truckloads) per year?

b. If not, what do the pumping companies do with that material in your area?

4. How is waste grease recovered from your facility and disposed of?

5. What is the quantity of waste grease you recover and dispose of per year?

6. Is the quantity increasing or decreasing? Why?

7. What are the costs of recovery and disposal?

8. Are there any alternative approaches to recovery and disposal?

9. Does waste grease have a market value? What is it?

10. Do you have any suggestions on how I should estimate the total amount of waste grease generated in the metropolitan area?

11. Do you have any suggestions on people I should contact, or approaches I should take? 


\section{Grease Collection/Rendering Companies}

Hello (introduction). I'm doing a study of urban waste grease resources for the National Renewable Energy Laboratory. Do you have a few minutes to answer some quick questions?

Company name:

Address:

Contact:

Phone number:

1. How do you obtain your waste grease supply?

2. What is the quantity of waste grease you collect or process per year?

3. Is the quantity increasing or decreasing? Why?

4. How much do you pay (or charge) for the waste grease you collect?

5. Do you process the waste grease into saleable products?

a. If yes, what products do you make from waste grease and sell? Amounts? Prices?

b. If no, where and how do you dispose of the material? Tipping fees?

6. Who are your biggest competitors? (names, numbers)

7. Who are your biggest customers?

8. Are there any factors that could change the demand for your products? What are they?

9. Do you have any suggestions on how I should estimate the total amount of waste grease generated in the metropolitan area?

10. Do you have any suggestions on people I should contact, or approaches I should take? 


\section{Restaurants}

Hello (introduction). I'm doing a study of urban waste grease resources for the National Renewable Energy Laboratory. Do you have a few minutes to answer some quick questions?

Company name:

Address:

Contact:

Phone number:

1. Do you have an estimate of the quantity of waste grease you generate per year?

2. Is the quantity increasing or decreasing? Why?

3. How do you dispose of it? Who takes it? (names, numbers)

4. How much do you receive for the waste grease? Is the price increasing or decreasing?

5. Are there any factors that could change the demand for your waste grease? What are they?

6. Do you have any suggestions on how I should estimate the total amount of waste grease generated in the metropolitan area?

7. Do you have any suggestions on people I should contact, or approaches I should take? 


\section{APPENDIX C -- REGRESSION PLOTS}

This Appendix presents a series of seven regression plots and statistical analyses, as discussed in Section B. All of the regression equations were specified to go through the origin, based on the assumption that a city with zero population would have no restaurants and would generate no waste grease. 
Number of Restaurants vs. Population: 30 Cities

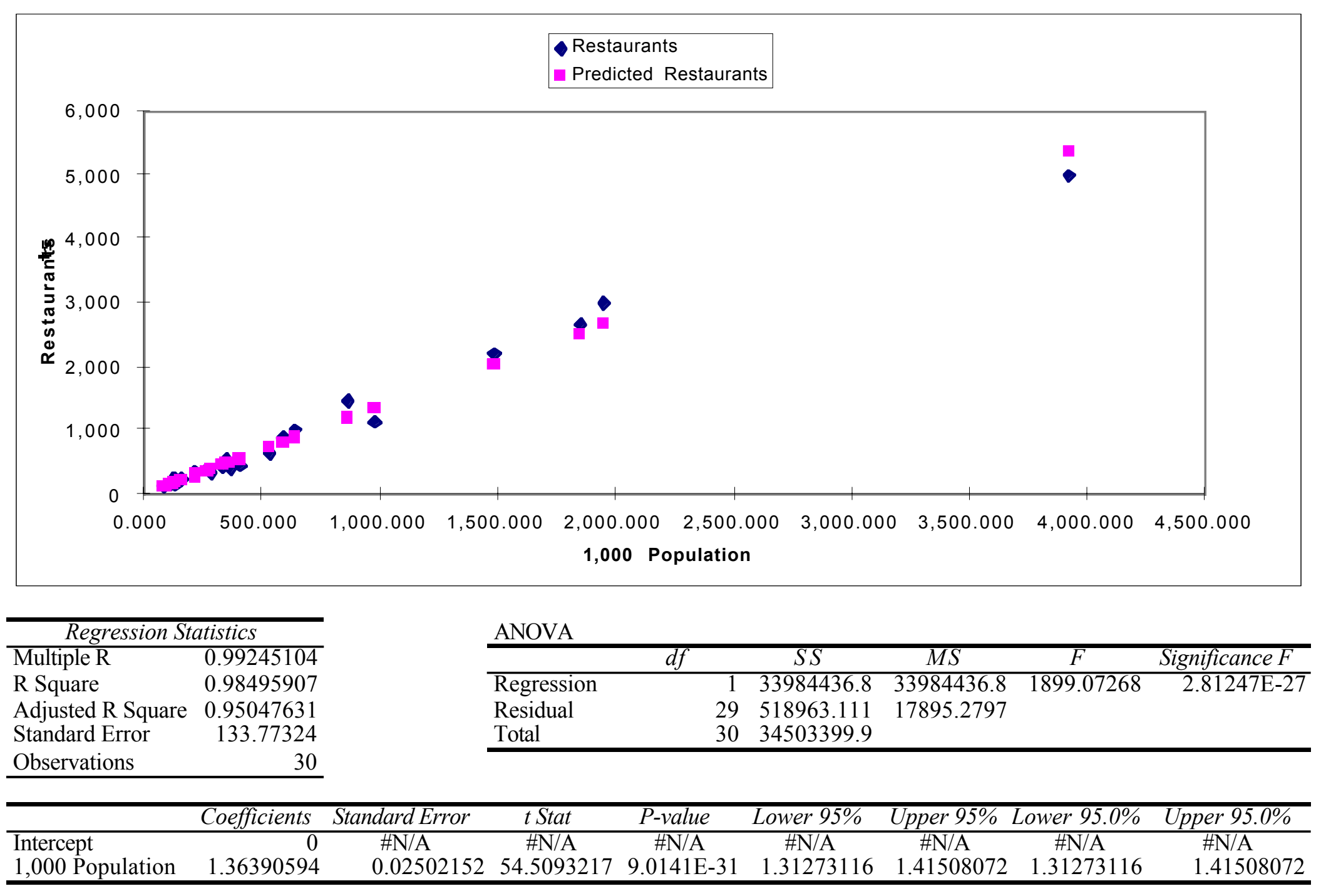




\section{Yellow Grease vs. Population: 30 Cities}

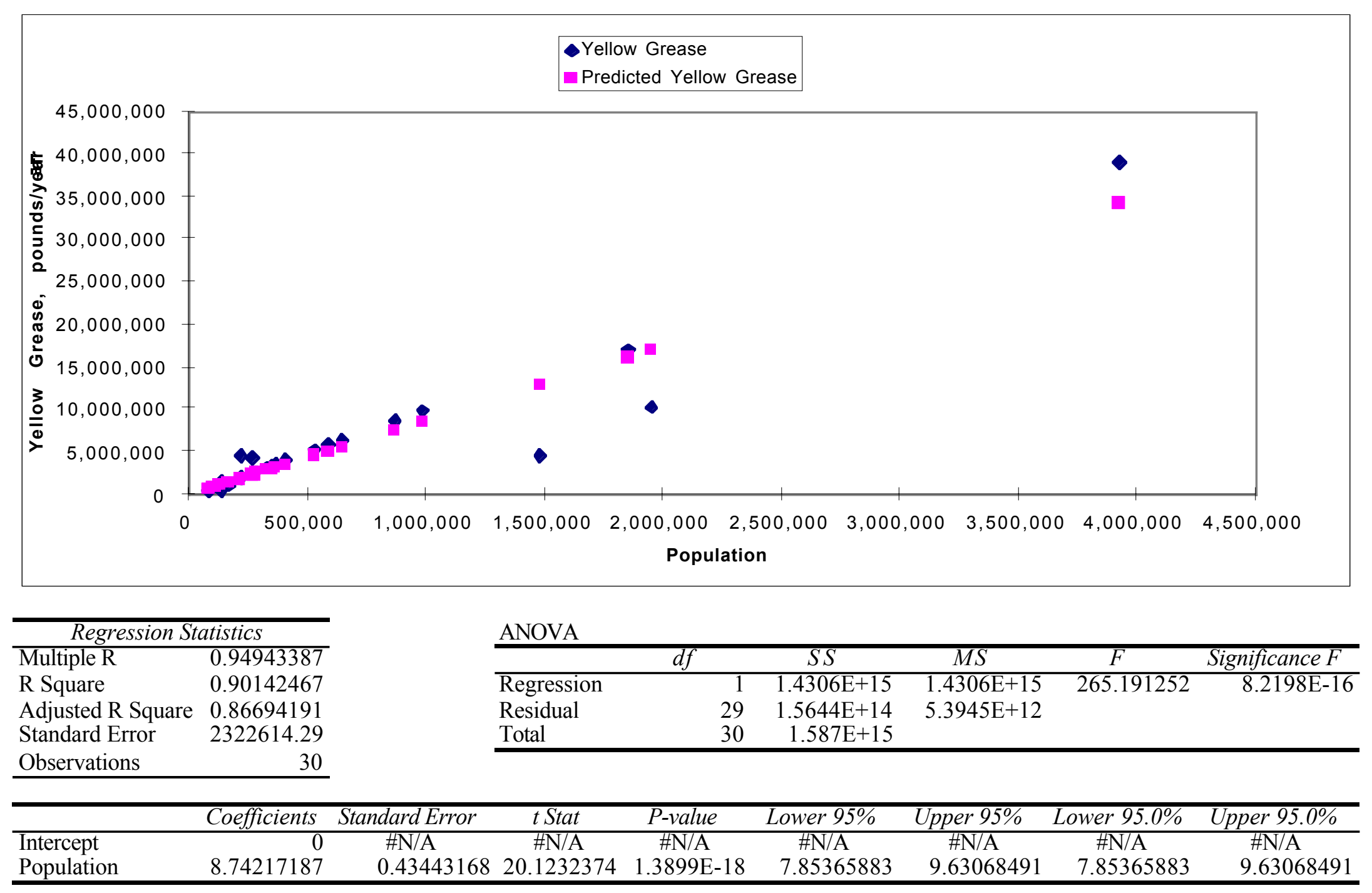


Trap Grease vs. Population: 30 Cities

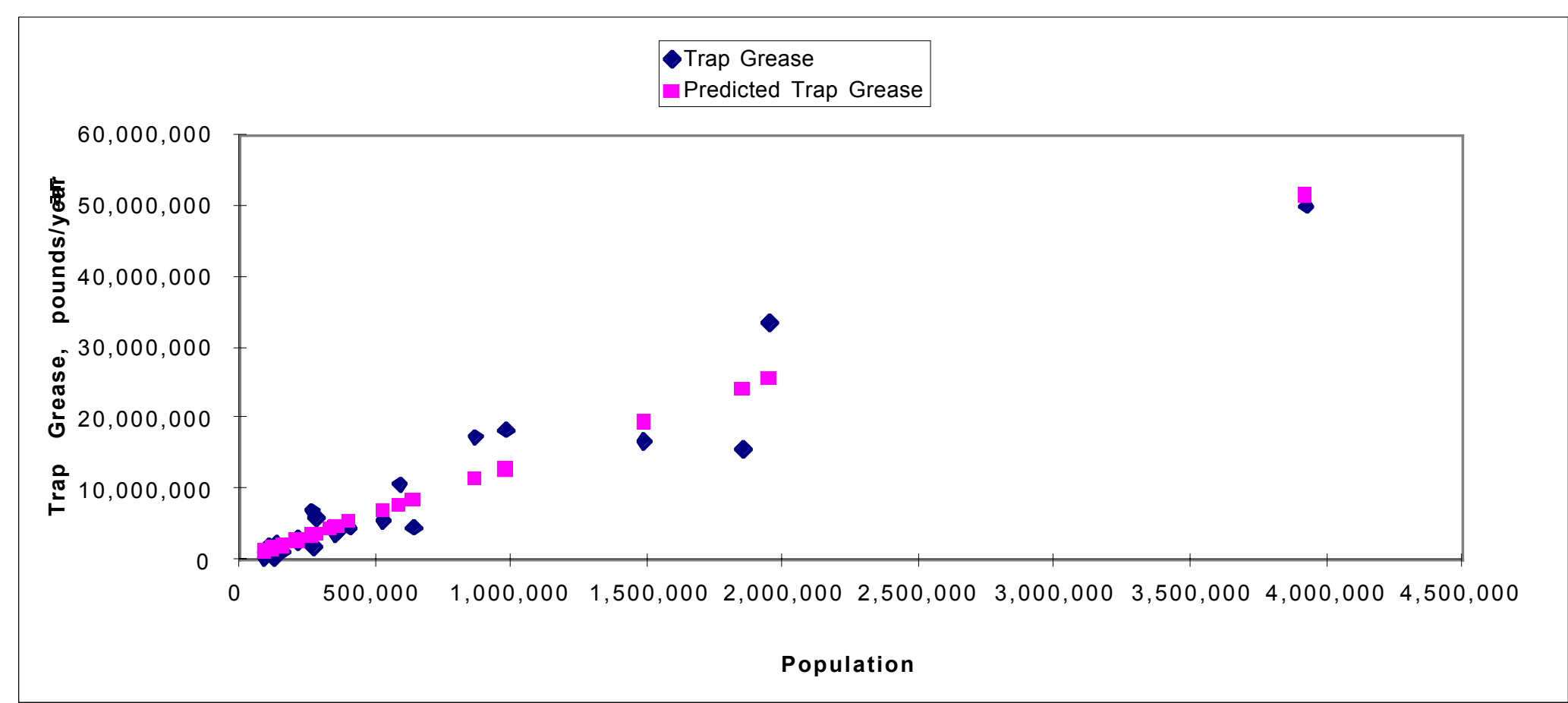

\begin{tabular}{|c|c|c|c|c|c|c|c|c|}
\hline \multicolumn{2}{|c|}{ Regression Statistics } & & \multicolumn{6}{|l|}{ ANOVA } \\
\hline Multiple R & 0.96103748 & & & $d f$ & $\overline{S S}$ & $\overline{M S}$ & $\bar{F}$ & Significance $F$ \\
\hline R Square & 0.92359303 & & Regression & 1 & $3.19458 \mathrm{E}+15$ & $3.1946 \mathrm{E}+15$ & 350.546531 & $2.2728 \mathrm{E}-17$ \\
\hline Adjusted R Square & 0.88911027 & & Residual & 29 & $2.64281 \mathrm{E}+14$ & $9.1131 \mathrm{E}+12$ & & \\
\hline Standard Error & 3018797.17 & & Total & 30 & $3.45886 \mathrm{E}+15$ & & & \\
\hline Observations & 30 & & & & & & & \\
\hline & Coefficients & Standard Error & t Stat & $P$-value & Lower 95\% & Upper 95\% & Lower $95.0 \%$ & Upper $95.0 \%$ \\
\hline Intercept & 0 & \#N/A & \#N/A & \#N/A & $\# \mathrm{~N} / \mathrm{A}$ & \#N/A & $\# \mathrm{~N} / \mathrm{A}$ & $\# \mathrm{~N} / \mathrm{A}$ \\
\hline Population & 13.1051642 & 0.5646487 & 23.2094119 & $2.805 \mathrm{E}-20$ & 11.95032734 & 14.2600011 & 11.9503273 & 14.2600011 \\
\hline
\end{tabular}


Total Grease vs. Population: 30 Cities

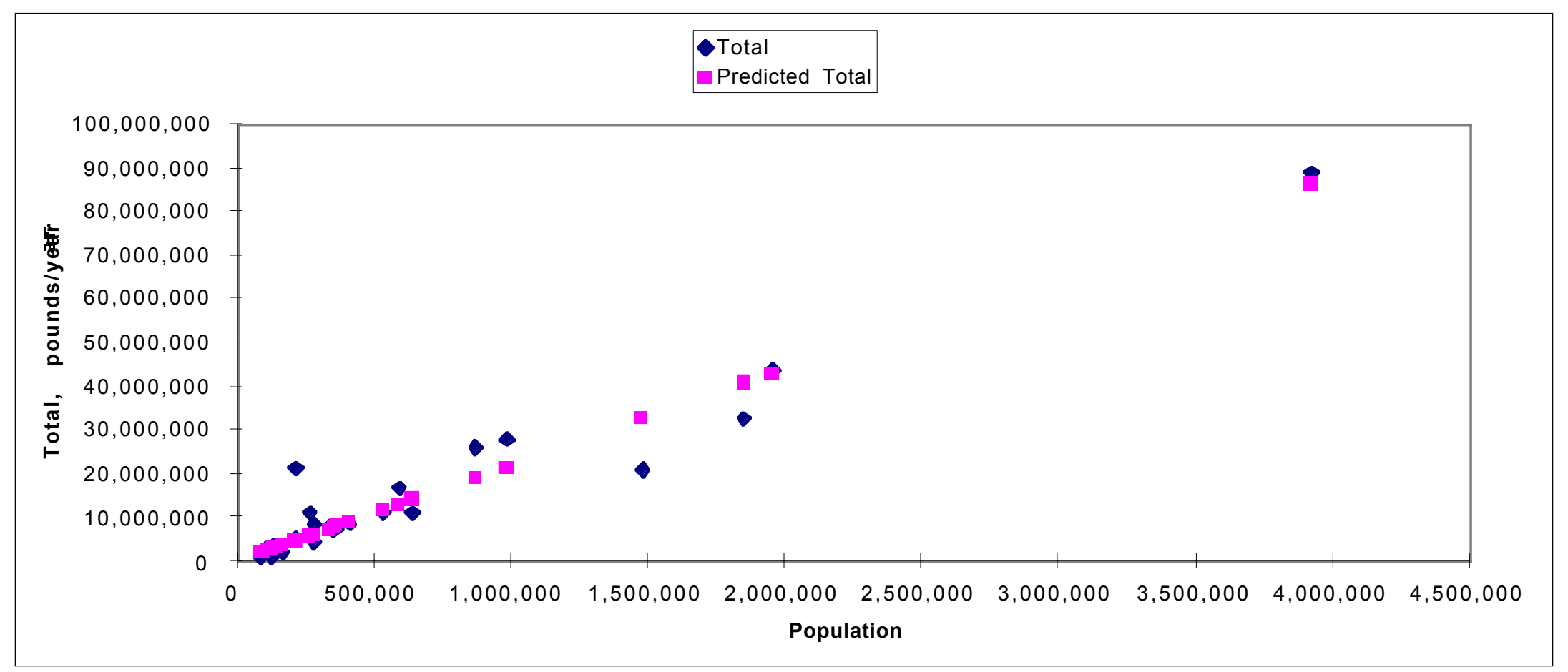

\begin{tabular}{lr}
\hline \multicolumn{2}{c}{ Regression Statistics } \\
\hline Multiple R & 0.96432492 \\
R Square & 0.92992255 \\
Adjusted R Square & 0.89543979 \\
Standard Error & 4745125.09 \\
Observations & 30 \\
\hline
\end{tabular}

\begin{tabular}{|c|c|c|c|c|c|}
\hline & $d f$ & $\overline{S S}$ & $\overline{M S}$ & $F$ & Significance $F$ \\
\hline Regression & 1 & $8.6649 \mathrm{E}+15$ & $8.6649 \mathrm{E}+15$ & 384.827854 & $6.7319 \mathrm{E}-18$ \\
\hline Residual & 29 & $6.5297 \mathrm{E}+14$ & $2.2516 \mathrm{E}+13$ & & \\
\hline Total & 30 & $9.3178 \mathrm{E}+15$ & & & \\
\hline
\end{tabular}

\begin{tabular}{lrccccccc}
\hline & Coefficients & Standard Error & $t$ Stat & P-value & Lower 95\% & Upper 95\% & Lower 95.0\% & Upper 95.0\% \\
\hline Intercept & 0 & \#N/A & \#N/A & \#N/A & \#N/A & \#N/A & \#N/A & \#N/A \\
Population & 21.9557142 & 0.88754843 & 24.7374828 & $4.8115 \mathrm{E}-21$ & 20.1404728 & 23.7709555 & 20.1404728 & 23.7709555 \\
\hline
\end{tabular}


Yellow Grease vs. Number of Restaurants: 30 Cities

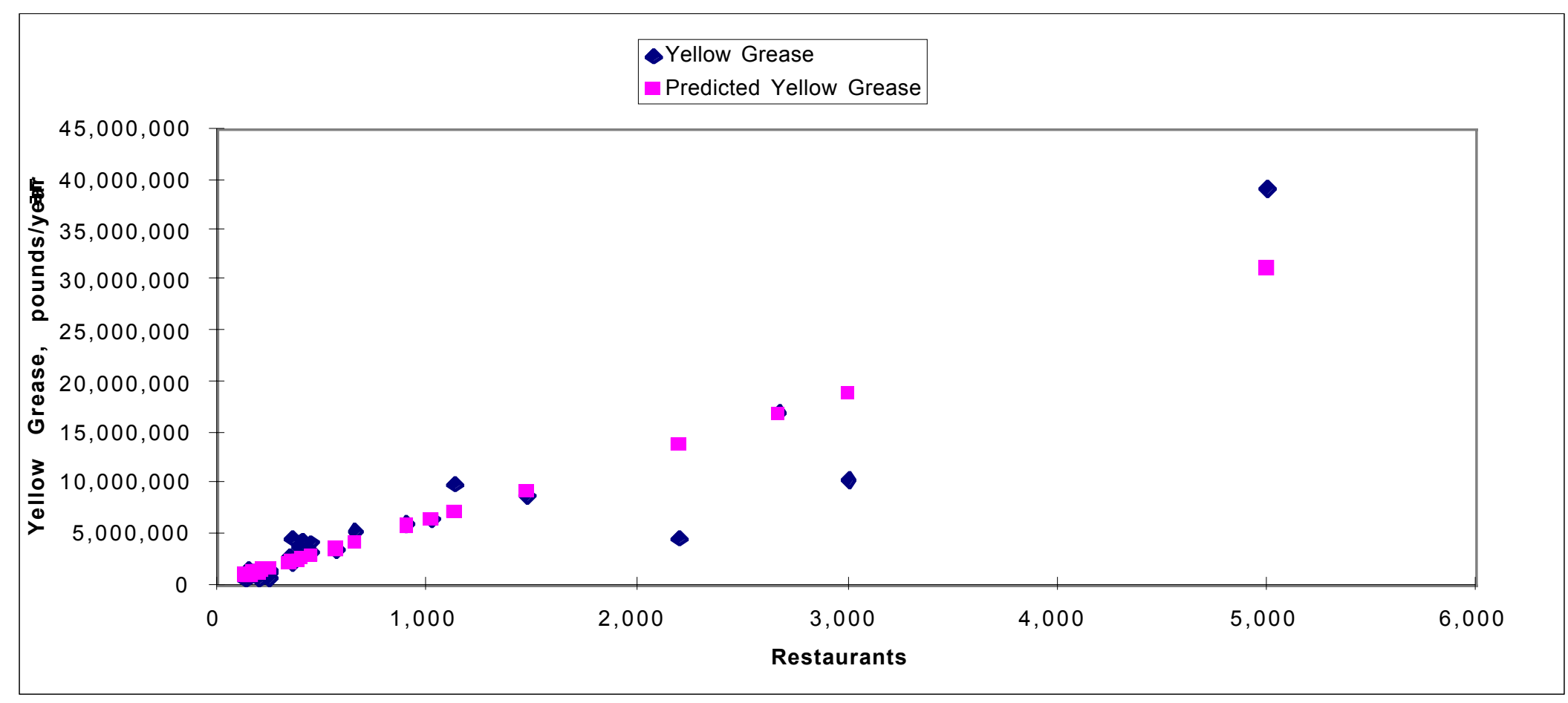

\begin{tabular}{|c|c|c|c|c|c|c|c|c|}
\hline \multicolumn{2}{|c|}{ Regression Statistics } & & \multicolumn{6}{|l|}{ ANOVA } \\
\hline Multiple R & 0.92139025 & & & $\overline{d f}$ & $\overline{S S}$ & $\overline{M S}$ & $\bar{F}$ & Significance $F$ \\
\hline R Square & 0.84895999 & & Regression & 1 & $1.3473 \mathrm{E}+15$ & $1.3473 \mathrm{E}+15$ & 163.002104 & $3.4051 \mathrm{E}-13$ \\
\hline Adjusted R Square & 0.81447723 & & Residual & 29 & $2.397 \mathrm{E}+14$ & $8.2657 \mathrm{E}+12$ & & \\
\hline Standard Error & 2875007.46 & & Total & 30 & $1.587 \mathrm{E}+15$ & & & \\
\hline Observations & 30 & & & & & & & \\
\hline & Coefficients & Standard Error & tStat & $P$-value & Lower 95\% & Upper 95\% & Lower 95.0\% & Upper $95.0 \%$ \\
\hline Intercept & 0 & \#N/A & \#N/A & \#N/A & \#N/A & \#N/A & \#N/A & \#N/A \\
\hline Restaurants & 6255.86374 & 392.36462 & 15.9440057 & $6.8871 \mathrm{E}-16$ & 5453.38755 & 7058.33993 & 5453.38755 & 7058.33993 \\
\hline
\end{tabular}


Trap Grease vs. Number of Restaurants: 30 Cities

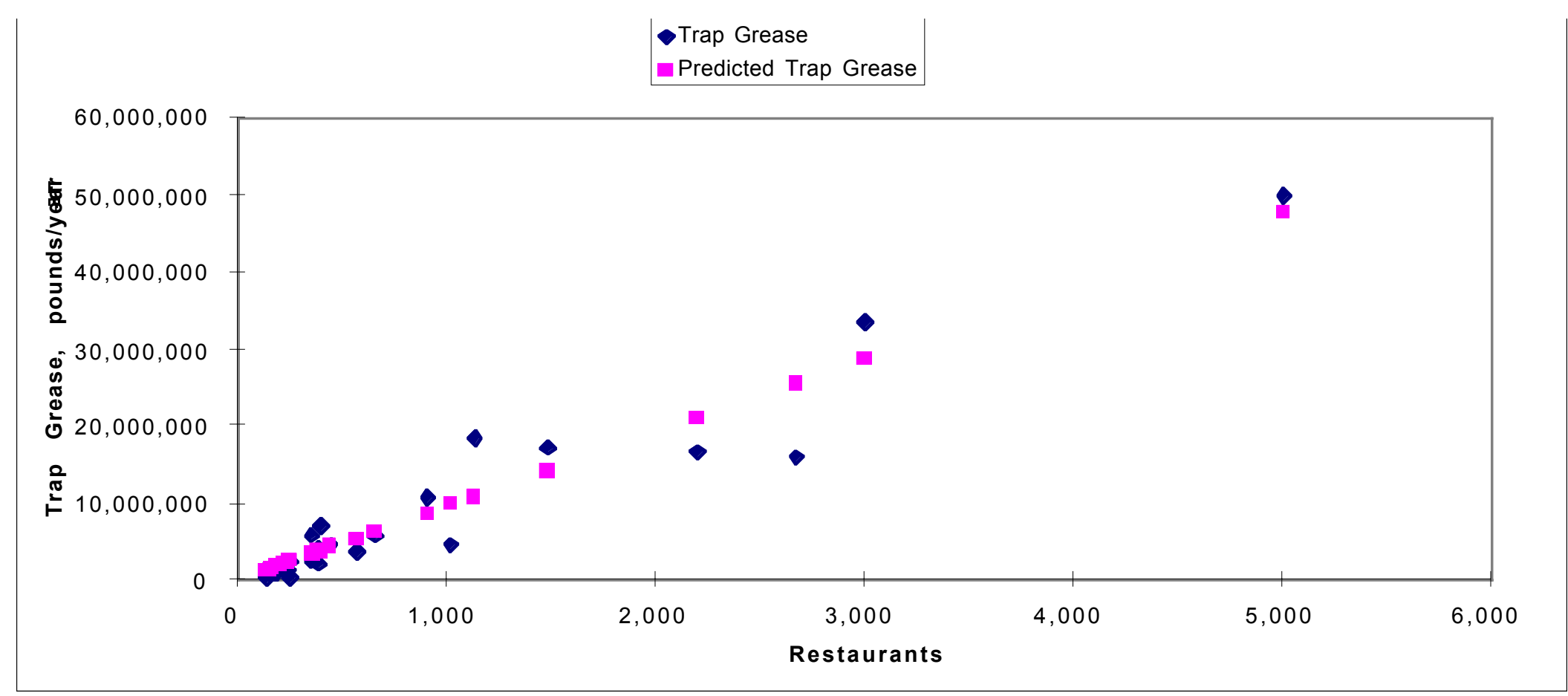

\begin{tabular}{|c|c|c|c|c|c|c|c|}
\hline \multicolumn{2}{|c|}{ Regression Statistics } & & \multicolumn{5}{|l|}{ ANOVA } \\
\hline Multiple R & 0.95957232 & & & $d f$ & $M S$ & $F$ & Significance $F$ \\
\hline R Square & 0.92077903 & & Regression & & $3.1848 \mathrm{E}+15 \quad 3.1848 \mathrm{E}+15$ & 337.064688 & $3.7814 \mathrm{E}-17$ \\
\hline Adjusted R Square & 0.88629627 & & Residual & & $2.7401 \mathrm{E}+149.4488 \mathrm{E}+12$ & & \\
\hline Standard Error & 3073884.39 & & Total & 30 & $3.4589 \mathrm{E}+15$ & & \\
\hline Observations & 30 & & & & & & \\
\hline & Coefficients & Standard Error & $t$ Stat & $P$-value & Lower 95\% Upper 95\% & Lower 95.0\% & Upper $95.0 \%$ \\
\hline Intercept & 0 & \#N/A & \#N/A & \#N/A & \#N/A & \#N/A & \#N/A \\
\hline Restaurants & 9552.5202 & 419.506209 & 22.7708673 & 4.7434E-20 & $\begin{array}{lll}8694.5332 & 10410.5072\end{array}$ & 8694.5332 & 10410.5072 \\
\hline
\end{tabular}


Total Grease vs. Number of Restaurants: 30 Cities

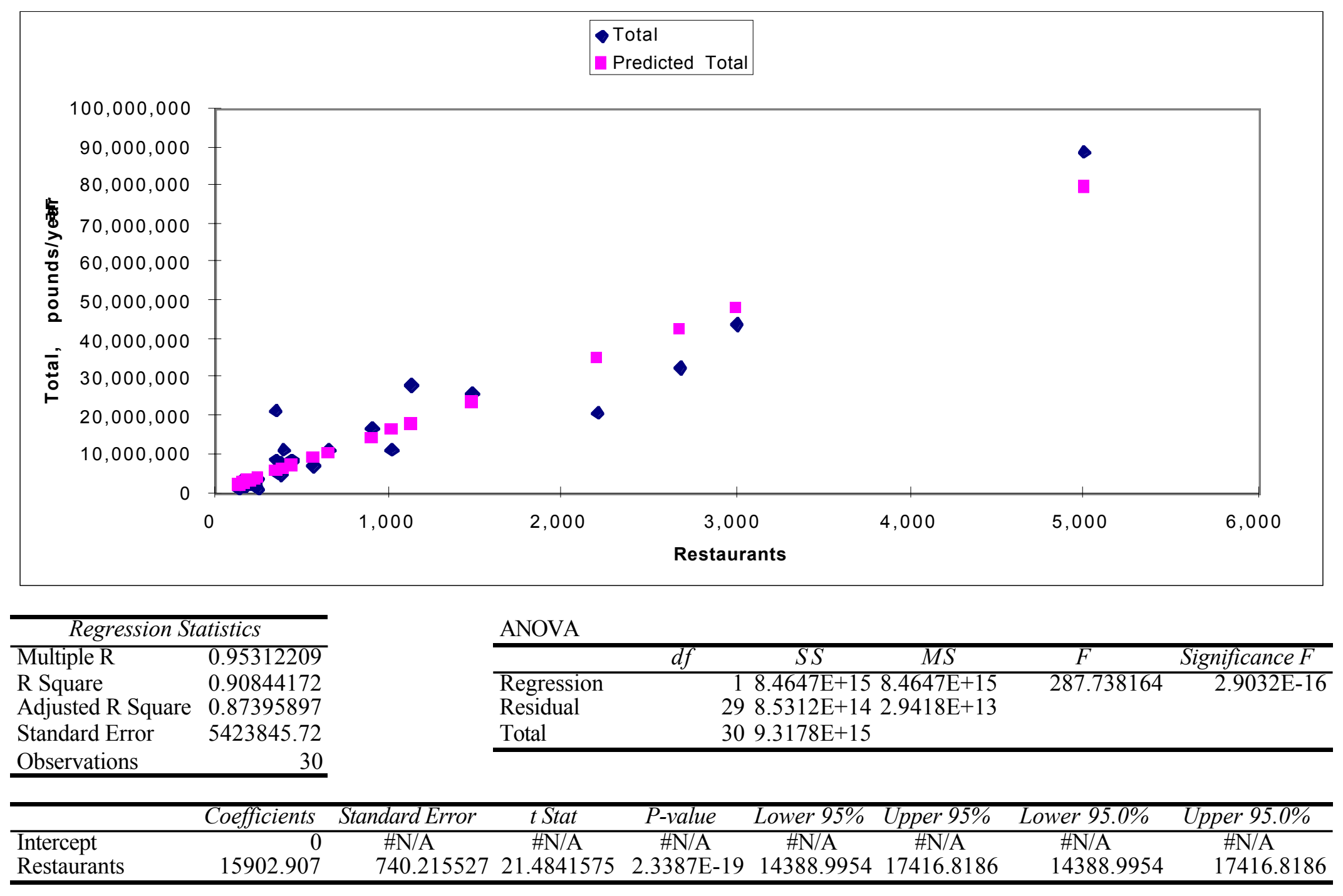




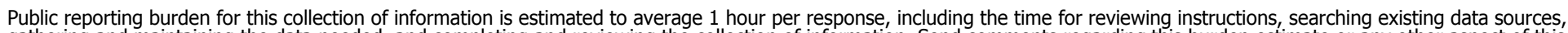

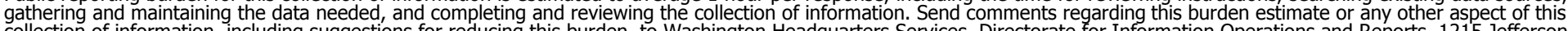

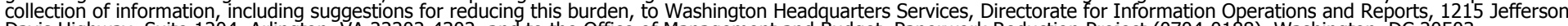

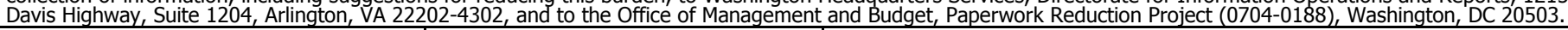

\begin{tabular}{|l|l|l|}
\hline 1. AGENCY USE ONLY (Leave blank) & $\begin{array}{c}\text { 2. REPORT DATE } \\
\text { November } 1998\end{array}$ & $\begin{array}{r}\text { 3. REPORT TYPE AND DATES COVERED } \\
\text { NREL Subcontract Report }\end{array}$ \\
\hline
\end{tabular}

4. TITLE AND SUBTITLE

November 1998

5. FUNDING NUMBERS

Urban Waste Grease Resource Assessment

6. AUTHOR(S)

G. Wiltsee

7. PERFORMING ORGANIZATION NAME(S) AND ADDRESS(ES)

Appel Consultants, Inc.

23905 Plaza Gavilan

Valencia, California

9. SPONSORING/MONITORING AGENCY NAME(S) AND ADDRESS(ES)

National Renewable Energy Laboratory

1617 Cole Blvd.

Golden, CO 80401-3393

Task \#: BF996001

8. PERFORMING ORGANIZATION REPORT NUMBER

11. SUPPLEMENTARY NOTES

NREL Technical Monitor: K.S. Tyson

12a. DISTRIBUTION/AVAILABILITY STATEMENT

National Technical Information Service

12b. DISTRIBUTION CODE

U.S. Department of Commerce

5285 Port Royal Road

Springfield, VA 22161

13. ABSTRACT (Maximum 200 words)

This study collected and analyzed data on urban waste grease resources in 30 randomly selected metropolitan areas in the United States.

Two major categories (yellow grease feedstock collected from restaurants by rendering companies; and grease trap wastes from restaurants, which can either be pumped into tank trucks for disposal or flow through municipal sewage systems into wastewater treatment plants) were considered in this study.

14. SUBJECT TERMS

15. NUMBER OF PAGES 70

16. PRICE CODE

17. SECURITY CLASSIFICATION OF REPORT
18. SECURITY CLASSIFICATION OF THIS PAGE
19. SECURITY CLASSIFICATION OF ABSTRACT
20. LIMITATION OF ABSTRACT

Standard Form 298 (Rev. 2-89)

Prescribed by ANSI Std. Z39-18 